Florida International University FIU Digital Commons

7-13-2005

\title{
Resources use and conservation attitudes of local people in the Western Terai landscape, Nepal
}

Nabin Baral

Florida International University

DOI: $10.25148 /$ etd.FI14050425

Follow this and additional works at: https://digitalcommons.fiu.edu/etd

Part of the Environmental Sciences Commons

\section{Recommended Citation}

Baral, Nabin, "Resources use and conservation attitudes of local people in the Western Terai landscape, Nepal" (2005). FIU Electronic Theses and Dissertations. 1387.

https://digitalcommons.fiu.edu/etd/1387

This work is brought to you for free and open access by the University Graduate School at FIU Digital Commons. It has been accepted for inclusion in FIU Electronic Theses and Dissertations by an authorized administrator of FIU Digital Commons. For more information, please contact dcc@fiu.edu. 
FLORIDA INTERNATIONAL UNIVERSITY

Miami, Florida

RESOURCES USE AND CONSERVATION ATTITUDES OF LOCAL PEOPLE IN THE WESTERN TERAI LANDSCAPE, NEPAL

A thesis submitted in partial fulfillment of the

requirements for the degree of

MASTER OF SCIENCE

in

ENVIRONMENTAL STUDIES

by

Nabin Baral

2005 
To: Interim Dean Mark Szuchman

College of Arts and Sciences

This thesis, written by Nabin Baral, and entitled Resources Use and Conservation Attitudes of Local People in the Western Terai Landscape, Nepal, having been approved in respect to style and intellectual content, is referred to you for judgment.

We have read this thesis and recommend that it be approved.

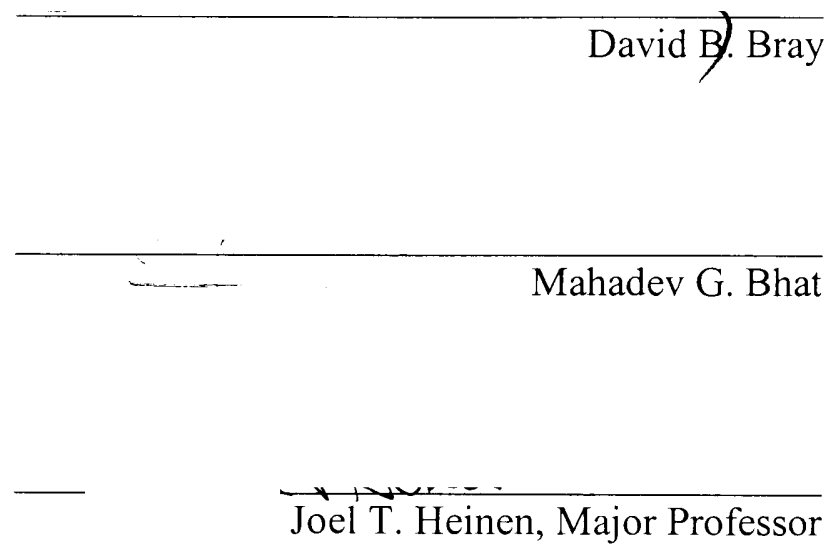

Date of Defense: July 13, 2005

The thesis of Nabin Baral is approved.

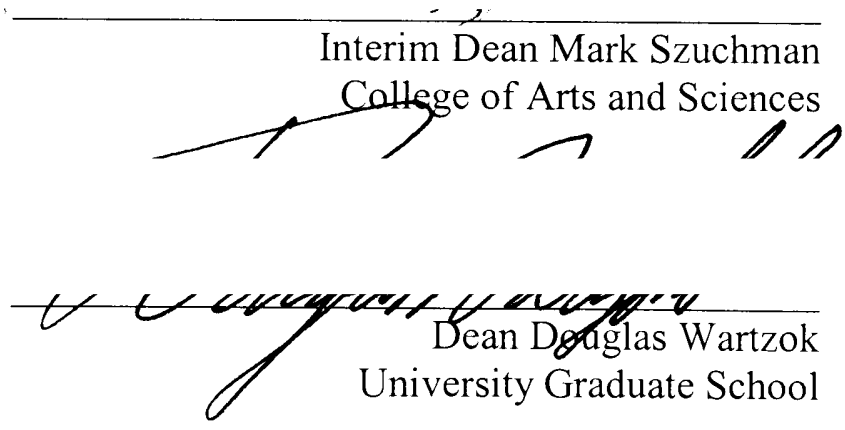

Florida International University, 2005 


\section{DEDICATION}

I dedicate this thesis to my TEACHERS of past, present and future. 


\section{ACKNOWLEDGMENTS}

I am grateful to many individuals and institutions who have contributed to the success of this research project. I thank the members of my thesis committee. I express my gratitude to my Major Professor, Dr Joel T. Heinen for his inspiration, guidance, and meticulous editing of solecisms. His positive attitudes were valuable in times of hardship during the fieldwork. I am indebted to my committee members: Dr Mahadev G. Bhat and Dr David B. Bray, who enlightened me with an ocean of knowledge. They were always interested in the project and provided me invaluable suggestions.

I could not have completed this thesis without financial assistance from numerous institutions. I thank the National Fish and Wildlife Foundation's Save the Tiger Fund and the Disney Conservation Fund for providing research grant that covered most of the field expenditures. I thank the Sigma Xi and the Institute of Asian Study, Florida International University for awarding a grant-in-aid for research and a travel grant, respectively. The Department of Environmental Studies awarded graduate assistantships.

I thank the Department of National Parks and Wildlife Conservation for granting permission to carry out research work in Royal Bardia National Park and Royal Suklaphanta Wildlife Reserve. Many staff of these parks helped me during the fieldwork. The King Mahendra Trust for Nature Conservation (KMTNC) provided accommodations in their field offices. I am thankful to Dr Shant Raj Jnawali, Naresh Subedi and Chiranjivi Pokharel, affiliated with the KMTNC, for their support in the field research. I appreciate hard work of my field assistants Kamal Thapa, Birendra Thapa, Janak Chaudhary, Rajendra Bhatta, and Dhan Chand. 
I am indebted to the alacrity of Thaneswar Tiwari and his family members when I was their guest in Mahendranagar. Birendra Tiwari, Dhan Bahadur Chand, Benu Gautam, and Prakash Tamang helped me in various ways.

I want to thank Dr Paulette Johnson and Oscar Saenz for their help in statistical consulting and Ms Sushila Nepali, WWF-Nepal Program, for providing literature on the Terai Arc Landscape project.

Nilesh it was great working with you.

I am lucky to have loving parents and wife who were always supportive. Thanks for your patience and perseverance when I was not at home. 


\section{ABSTRACT OF THE THESIS \\ RESOURCES USE AND CONSERVATION ATTITUDES OF LOCAL PEOPLE IN \\ THE WESTERN TERAI LANDSCAPE, NEPAL}

by

\section{Nabin Baral}

Florida International University, 2005

Miami, Florida

Professor Joel T. Heinen, Major Professor

Two protected areas: Royal Bardia National Park (RBNP) and Royal Suklaphanta Wildlife Reserve (RSWR) in the Western Terai, Nepal, are under threats due to present political turmoil, uncontrolled immigration, inefficient land reform policies and unsustainable resource use. I did a stratified random questionnaire survey of 234 households to determine how resource use patterns and problems influence conservation attitudes. Chi-square, Student's t, Mann-Whitney and Kruskal-Wallis tests, and multiple regression were used. There was spatio-temporal variability in resource use patterns and dependency. People were collecting eight and seven types of resources in RBNP and RSWR, respectively. However, people in RBNP were more dependent on resources than RSWR. In both areas, the problem of firewood is serious. The mean attitude score of RBNP $(8.4 \pm 1.44)$ was significantly higher than the score of $\operatorname{RSWR}(7.7 \pm 1.66 ; \mathrm{t}=3.24$, $\mathrm{p}=0.0007)$. Conservation attitude was determined by variables such as participation in trainings, wildlife damage, and satisfaction towards user groups. 


\section{TABLE OF CONTENTS}

CHAPTER

1 INTRODUCTION

1.1 Evolution of the Conservation Concept

1.1.1 Fortress and fine conservation

1.1.2 Participatory conservation

1.1.3 Landscape conservation

1.2 Literature Review

1.3 Research Goal, Questions and Hypotheses 12

2 THE STUDY AREA $\quad 14$

$\begin{array}{ll}2.1 \text { Ecological Divisions } & 14\end{array}$

2.2 Location $\quad 15$

2.3 Geology and Soils $\quad 16$

$\begin{array}{ll}2.4 \text { Climate } & 17\end{array}$

$\begin{array}{ll}2.5 \text { Vegetation } & 18\end{array}$

$\begin{array}{ll}2.6 \text { Wildlife } & 19\end{array}$

$\begin{array}{ll}2.7 \text { Settlements } & 20\end{array}$

2.8 Ethnographies $\quad 20$

3 MATERIALS AND METHODS 24

3.1 Selection of Villages $\quad 24$

3.2 Household Survey 24

3.2.1 Household survey team $\quad 24$

3.2.2 Survey instrument $\quad 25$

$\begin{array}{ll}3.2 .3 \text { Survey procedure } & 25\end{array}$

3.3 Sample Size and Sampling 26

3.4 Survey of User Groups (UGs) 27

$\begin{array}{ll}\text { 3.5 Survey Limitations and Constraints } & 27\end{array}$

$\begin{array}{ll}3.6 \text { Statistical Analyses } & 28\end{array}$

$\begin{array}{ll}4 \text { RESULTS } & 30\end{array}$

4.1 Demographic Characteristics of Respondents $\quad 30$

4.1.1 Gender and age $\quad 30$

4.1.2 Ethnicity 31

4.1.3 Education 31

4.1.4 Occupation $\quad 32$

4.1.5 Family size $\quad 33$

4.2 Migration and Economic Status 34 
4.3 Resource Use Patterns and Dependency 37

4.4 Participation in Conservation 42

4.5 Conservation Attitudes 43

4.6 Wildlife Harassment and Attitudes towards UGs 46

4.7 Institutional Development and Strengthening 47

4.7.1 Institutional working procedures $\quad 47$

4.7.2 Resource management and demand fulfillment 49

4.7.3 Attitudes of conservation leaders $\quad 50$

4.7.4 Content analysis of the work plans $\quad 51$

5 DISCUSSION $\quad 52$

6 CONCLUSIONS

$\begin{array}{lr}\text { REFERENCES } & 86\end{array}$

$\begin{array}{lr}\text { APPENDICES } & 96\end{array}$ 


\section{LIST OF TABLES}

TABLE

Table 1. Frequency distribution of ethnicity in two protected areas

Table 2. Frequency distribution of education level of respondents of two areas 73

Table 3. Comparison of family size between area and ethnic groups

Table 4. Percentage of immigrants in two protected areas

Table 5. Average landholdings in hectare among different ethnic groups in two areas

Table 6. Percent of respondents meeting need of staple food from their farm

Table 7. Average and range of livestock size unit in two protected areas

Table 8. Frequency of resources harvested by respondents of two protected areas

Table 9. Nonparametric correlation of resource use score with continuous variables

Table 10. Frequency distribution of resource dependency in two areas

Table 11. Number and percentage of households mentioning the grazing sites

Table 12. Number and percentage of households mentioning the source of fodder

Table 13. Number and percentage of households mentioning the source of energy

Table 14. Number and percentage of respondents suggesting measures to solve the problem of firewood scarcity

Table 15. Frequency distribution of households participating in conservation interventions in two areas

Table 16. Percent of respondents agreeing or disagreeing with conservation statements 
Table 17. Multiple regression of conservation attitude score on demographic and socioeconomic variables

Table 18. Frequency distribution of mode of Users' Group formation

Table 19. Perception of UG chairs on effective institute for resource management

Table 20. Frequency distribution of responses whether UGs are fulfilling demands

Table 21. UG chairs' attitudes towards TAL in two areas

Table 22. UG chairs attitudes towards the BZMR and Guideline

Table 23. Losses of agencies under the Ministry of Forest and Soil Conservation 


\section{LIST OF FIGURES}

FIGURE

Figure 1. Map of Nepal depicting spatial distribution of protected areas

Figure 2. RBNP and RSWR with sampled households in the buffer zones

Figure 3. Average minimum and maximum monthly temperatures of two areas for the period 1987-2001

Figure 4. Average monthly precipitation of two areas for the period 1987-2001

Figure 5. Percentage of male and female respondents in two protected areas

Figure 6. Percent of respondents in five occupation categories

Figure 7. Average family size among ethnic groups in two areas

Figure 8. Average landholdings among ethnic groups in two areas

Figure 9. Frequency of households rearing four types of livestock in two areas

Figure 10. Total number of tourist arrival per year since the beginning of the Maoists insurgency 


\section{ACRONYMS AND ABBREVIATIONS}

BZMR Buffer Zone Management Regulation

CBC Community-based Conservation

CBS Central Bureau of Statistics

CITES Convention on International Trade in Endangered Species of Wild Fauna and Flora

DNPWC Department of National Parks and Wildlife Conservation

HMG His Majesty Government

IUCN World Conservation Union

LSU Livestock Size Unit

MFSC Ministry of Forests and Soil Conservation

NGO Non-Governmental Organization

NTFP Non-Timber Forest Product

RBNP Royal Bardia National Park

RSWR Royal Suklaphanta Wildlife Reserve

TAL Terai Arc Landscape

UG User Group

UNESCO United Nations Educational Scientific and Cultural Organization

ha hectare

kg kilogram

mm millimeter

sq $\mathrm{km} \quad$ square kilometer 


\section{INTRODUCTION}

\subsection{Evolution of the Conservation Concept}

Developing countries are facing the dilemma of balancing conservation and human needs. They have limited natural resources and populations are growing at exponential rates, while productivity gains through improved agricultural production lag behind. Economic development and population growth in the absence of more sustainable development is resulting in environmental degradation. Setting up a network of protected areas for the conservation of biodiversity is a step to address environmental degradation. The Nepalese government adopted the concept of protected areas in the early 1970s. The modern era of conservation of both natural areas and species began with the passage of National Parks and Wildlife Conservation (NPWC) Act 1973 by His Majesty's Government of Nepal (HMG 1973; Heinen \& Kattel 1992). The Act established the Department of National Parks and Wildlife Conservation (DNPWC), and also gave authority to DNPWC to declare any piece of land, forest or wetland important from biological, sociological and historical perspectives within the network of protected areas. A series of protected areas was established to conserve vulnerable habitats and endangered species. At present, there are four types of protected areas established by the law which fall in three categories recognized by World Conservation Union (IUCN). These are: nine national parks (Category II), three wildlife reserves (Category IV), one hunting reserve (Category VI) and three conservation areas (Category VI; Sharma \& Yonzon 2005). These are scattered throughout the country (Figure 1). The Fourth Amendment of NPWC Act 1973, passed in 1993, vested the DNPWC the authority to declare buffer zones in the periphery of protected areas (Heinen \& Mehta 2000). So far, 
seven designated buffer zones (Category VI) have added significant areas under special management and protection (Sharma \& Yonzon 2005). Two national parks are included as UNESCO World Heritage Sites and four wetlands are designated as Ramsar sites under IUCN-the World Conservation Union. Including buffer zones, about $18 \%$ of the total land area $(147,181 \mathrm{sq} \mathrm{km})$ of Nepal is under protected status. The evolution of the conservation concept is passing through a 'learning curve' phase and there is always an opportunity to improve. Nepal has tried different approaches to conservation and their impacts on ecology, economics and society are briefly summarized.

1.1.1 Fortress and fine conservation: Nepal's conservation movement began with active protection of species and habitats. The approach was to replicate the prototype of Yellowstone and local people were excluded from these lands. This conservation philosophy was based on protectionist policies that discouraged every form of resource use. The people who had been using available resources lost their traditional usufruct rights. The goal of management was to restore populations of flagship species, and there have been notable advances in some parks (Mishra 1982). The population of one-horned rhinoceros Rhinoceros unicornis reached 612 individuals in 2000 from all time low of 55 individuals in the 1960s. Similarly, the population of Bengal tiger Panthera tigris increased from 55 individuals in the 1970s to 300 individuals in 2000 (DNPWC 2001). The control of poaching and protection of habitats allowed wildlife populations to increase. The 'preservation-oriented' approach was successful in conserving endangered species of wildlife (Heinen \& Yonzon 1994) at a high social cost. The approach was easier to conceptualize and had measurable success (Heinen \& Mehta 2000), but some 
second generation issues such as park-people conflicts, ownership of resources and equitable distribution of benefits have emerged. Reconciling issues of strict protection versus sustainable livelihoods may garner greater support for conservation in developing countries. Soliciting people's participation in conservation is a well thought strategy to this end.

1.1.2 Participatory conservation: As a general rule, extraction of resources inside protected areas is prohibited (HMG 1973) but if the park authority deems it necessary, then some resources can be extracted for use by local people. In response to the perceived tensions caused by the designation of protected areas and by way of compensation for loss of rights to various resources inside the protected area, the granting of some resource extraction rights, such as the collection of grasses for two weeks per year, developed in 1978, five years after the establishment of protected areas (Mishra 1982). Management authorities realized that conservation is counterproductive if stringent laws are enacted to forbid local people from subsistence resource use. Resources such as thatch and firewood decreased substantially outside the protected areas and local people have no alternative other than harvest illegally from the park.

Exclusion of local people and restrictions on local-level usury rights have made the 'fortress and fine' model less appropriate in the context of developing countries such as Nepal (Heinen 1996). Furthermore, this approach of conservation brings hardships to poor, rural people living in or around the protected areas who are heavily dependent on natural resources for their living. While biodiversity conservation brings global benefits, 
there can be few benefits and high costs to local communities. Even with the concession of grass harvesting once a year, many model parks and reserves failed to solicit favorable attitudes and park-people relationships were poor (Mishra 1982; Heinen 1993; Nepal \& Weber 1995; Studsrod \& Wegge 1995; Mehta 1996). After realizing the fact that protected areas cannot operate as islands in the matrix of human habitation, the government gradually changed its policy from exclusion to inclusion of local people in protected areas management.

After 1980, conservation communities worldwide realized that humans are an integral part of ecosystems, so that, for the sustainability of the ecosystem, human dimensions in conservation should be aptly addressed. The publication of the IUCN's World Conservation Strategy of 1980 has been a catalyst for more 'all-encompassing' conservation thinking (Infield 1988). Multi-national donor agencies, non-governmental organizations (NGO) and foreign governments set criteria of participation by and empowerment of local people for funding in nature conservation (IUCN 1991; Kemf 1993; Gibson \& Marks 1995). Lessons learned from past experiences and changes in policies of donor agencies spurred governments to pass legislation allowing for conservation areas in addition to more strictly protected areas such as national parks and wildlife reserves. However, there have been significant dissenting voices that suggest strict protection remains the highest priority for conservation interests (Brandon et al. 1998). Nonetheless, in Nepal public policy has pursued a more conciliatory approach. In conservation areas in Nepal, local people are empowered to some extent in the management and utilization of natural resources (HMG 1996). The ratification of Buffer 
Zone Management Regulations 1996 provided the DNPWC with legal power to earmark a certain percent (30-50) of revenue generated by parks and reserves to local communities residing in buffer zones for various activities prioritized by local people, and the concession of resource harvest such as firewood, timber, thatch, fodder etc. for subsistence needs was provided within buffer forests. Various integrated conservation and development activities have been carried out in buffer zones and conservation areas to meet the dual goals of environmental protection and economic development. This participatory approach of management bolstered park-people relationships and attitudes towards conservation have improved in some parks (Heinen \& Mehta 1999).

1.1.3 Landscape conservation: The size of protected areas in developing countries is in many cases too small to harbor viable populations of megafauna (Dinerstein \& Wikramanayake 1993). Protected areas are islands in human habitation and landuse patterns outside protected areas may not be always compatible with conservation. One of the challenges for conservationists is how to increase the functional size of protected areas in developing countries by increasing habitat even in intensively used areas. Connecting already existing protected areas with habitat corridors and connectivity in human-dominated landscapes is one obvious approach to this end. Managing the entire landscape as an intact ecosystem will help secure the existence of protected areas in developing countries. The Nepalese government realized the imperative of the landscape approach and targeted the Terai region for implementation. The Nepalese Terai, the lowlands along Nepal's southern border with India, is very important from the conservation perspective because it harbors internationally endangered megafauna and 
has intact sub-tropical forests of high conservation value. The region boasts the most productive protected areas of Nepal.

The Terai Arc Landscape (TAL) encompasses one of the richest ecosystems in the eastern Himalaya ecoregion. It has an area of $49,500 \mathrm{sq} \mathrm{km}$ and extends from the Bagmati River in Nepal to Yamuna River in India (MFSC 2004). The goal of the project is to create a single functioning landscape by connecting 11 protected areas of Nepal and India through corridors. The landscape is very important for the survival and metapopulation dynamics of charismatic megafauna such as the Royal Bengal tiger, onehorned rhinoceros and Asian elephant Elephas maximus. The Nepali portion of TAL covers about half $(23,199 \mathrm{sq} \mathrm{km})$ of the total area, and comprises four protected areas, government forests and community forests. There are 86 species of mammals, 550 species of birds, 47 species of herpeto-fauna, 126 species of fishes, and over 2,100 species of flowering plants found in TAL (MFSC 2004). Recognizing the conservation importance of TAL, the government of Nepal identified it as a priority landscape for biodiversity conservation in the $10^{\mathrm{TH}}$ Five Year Plan (2003-7). The major thrust of the program is sectoral integration for planning, implementation, and monitoring and evaluation.

The Nepalese government ventured into an ambitious landscape conservation program that spans over 50 years. The success of the program would be determined by participation and attitudes of local people. Local people would be given incentives to become active stakeholders in conservation initiatives and influence decision-making 
processes that ultimately determine their livelihood. The Landscape approach to conservation is promising as it integrates social, ecological, and economic sectors and uses synthetic principles for achieving a sustainable future across an entire landscape.

Within a short span of time, Nepal has come a long way in conservation. Although the Nepalese government has not formally adopted adaptive management, in practice various conservation models have been designed, implemented and evaluated based on 'learning by doing' philosophy to narrow the rift between conservation and sustainable development. Lessons learned from different approaches were incorporated to improvise conservation rules and regulations. Nepal is now considered as a leader among developing nations with regard to conservation programs and legislation (Heinen \& Kattel 1992) and future courses of action for better management of resources will depend on attitudes and participation of local people who are the principal stakeholders in conservation. However, in the last several years, the Maoist People's War is throttling the past achievements of the conservation sector (Appendix 1). The War started in 1996 and has had adverse consequences in social, political, and economic sectors. Since the inception of the War, the conservation sector has been badly hit and consequences are now appearing. To meet new challenges, conservation agencies should reconsider the present models (Price 2003). To this end, the evolution of landscape conservation is promising. My goal is to evaluate how various conservation models have facilitated resource allocation and influence conservation attitudes, and provide baseline data for social impact assessment to gauge effectiveness of landscape approach in the western Terai of Nepal. 


\subsection{Literature Review}

The conservation attitudes of local people residing around protected areas (PA) determine the fate of protected areas in the long run. It is important for protected area managers to explore what factors influence conservation attitudes. The literature suggests that influential factors can be grouped into demographic, cultural and socioeconomic phenomena (Ite 1996) that largely determine local support or resentment to PAs. Although results are specific to geographical areas, demographic variables such as gender, age, education, occupation and ethnicity are generally found to be significant predictors of conservation attitudes (Fiallo \& Jabcobson 1995; Mehta \& Kellert 1998; Gillingham \& Lee 1999; Sah \& Heinen 2001). Attitudinal surveys are indispensable tools for social impact assessment and are widely used in the conservation sector. Attitude surveys do not record actual behavior, so do not predict conservation actions. Favorable conservation attitudes may not always ensure desired action on the part of local people; however, probability of conservation actions increases if people have favorable attitudes. Attitudinal surveys could be conservatively used as an indicator of participation by local people in collective actions.

Culture plays an important role in natural resource management. Traditional rituals and customs of tribal people can impose restrictions on the exploitation of resources (Anderson 2001). Local people may also participate in conservation programs due to incentives from projects such as ecotourism. The Community Baboon Sanctuary of Belize is an example where local people are voluntarily participating in howler monkey conservation (Hartup 1994), in the hopes that increased income from ecotourism will 
compensate for agricultural lands left in corridors for the monkeys. With respect to culture, religion has been suggested to inculcate a high regard for wildlife in some parks of India, and local people have shown favorable attitudes to conservation in spite of substantial economic loss due to wildlife damage (Sekhar 1998). Resource use patterns of ethnic tribes and immigrants draw attention for sustainability of resources. Although there have been no significant differences in deforestation based on cultural and ethnic background (Sierra 1999), non-indigenous people can cause significantly more change in structure and composition of tropical forests (Nepstad et al. 1992). The dependency on resources could be a function of culture. The indigenous Tharus are more dependent on natural resources than other groups in South Asia (Brown 1997). Understanding cultural perspectives of resource use and how they influence conservation attitudes provides insights for strategic management. In recent years, because of the Maoist insurgency many people migrated from the mountain districts to the Western Terai. The large-scale migration has caused ethnic heterogeneity, which will influence resource use patterns and problems (Heinen 1996).

Conservation attitudes are generally influenced by the perceived costs and benefits of PAs. People tend to have favorable attitudes to conservation when are allowed to use park resources (Newmark et al. 1993), and they tend to be alienated when restrictions are imposed (Heinen 1993). Whether local people should be given access rights over resources within parks remains a contentious issue. Resource use restrictions bring hardships and incur substantial costs to people residing in the periphery of the park. Local people frequently offset costs by harvesting resources from parks illegally (Straede \& 
Helles 2000). Resenting resource restrictions, people demand usufruct rights over resources within parks and reserves (Gullingham \& Lee 1999). Success of conservation measures is gauged by tangible and immediate benefits that people derive (McNeely 1993), and this helps to solicit active participation of people in sustainable management of natural resources.

Economic incentives are very important tools to influence conservation attitudes. In general, people who receive goods and services personally have more favorable attitudes than those who don't (Infield 1988; Newmark et al. 1993). Economic incentives even out incurred costs of local people and provide socioeconomic benefits. However, inequitable distribution of benefits engenders problems. Parry and Campbell (1992) found that local people had negative attitudes in spite of receiving substantial benefits from conservation in Africa because the rich benefited more from tourism. Distinctions should be made regarding how benefits are distributed at community and household levels. These provide guidance to resource managers on the use of economic incentives for sustainable resource management.

Natural resources are the basis of both subsistence and market based economics. Sustainability of resources and economic development of the area depend on dynamic interactions between two. More emphasis is given to non-timber forest products (NTFP) than timber when concession of resources is granted within the park to meet subsistence needs and to earn cash (Hedge \& Enters 2000) because local people are more dependent on NTFPs and they are easier to regulate. Marginal communities use forest resources in 
varied fashions, timber for domestic use, fuelwood for energy, honey, fruit, mushrooms, bushmeat for food and medicinal plants for traditional healing, and NTFP harvesting complements the subsistence economy of poor and underprivileged people (Makwerere 1996). Sustainable harvesting of NTFPs is put forward as a tool for silvicultural management (Mahapatra \& Mitchell 1997; Schreckenberg 1999), and could generate employment, income and economic development in the periphery of protected areas. Research has shown that NTFPs contribute about $17 \%$ of household's annual income in South Asia (Mahapatra \& Mitchell 1997). There are caveats; when the subsistence economy is overtaken by the market economy, resources use tends to be unsustainable (Yonzon \& Hunter 1991). Collection of NTFPs is an opportunity to reduce indirect and opportunity costs of conservation borne by local people residing in the periphery of parks. It has also been promoted as an integrated approach to ameliorate park-people relations and improve attitudes (Archabald \& Naughton-Treves 2001).

Now it is a common practice of park management to address development needs of peripheral communities. However, some conservationists criticize the development approach of conservation because it may attract large number of immigrants due to greater economic opportunities and agricultural development assistance (Robinson 1993; Oates 1995). Socially, immigration results in ethnic heterogeneity (Noss 1997) that may result in inter-ethnic conflicts in resources use and management. Ecologically, immigration disrupts ecosystems (Shreckernberg 1999), thus hastening the exploitation of resources to an unsustainable level. Many integrated conservation and development projects failed to achieve their goals when they could not curb development-induced 
immigration (Southgate \& Clark 1993; Oates 1995; Noss 1997). The Western Terai of Nepal has received large number of immigrants over the past three decades due to social, political and environmental reasons. Therefore, understanding resource use patterns of immigrants is very important to form management strategies for sustainable resource use.

People's attitudes are decisive to achieve conservation goals (Richards 1996), but park management should not be guided solely by attitudes of local people (Infield \& Namara 2001) because attitudes are volatile, do not necessarily reflect actual behavior, and some events may have strong short-term influences over them. Nevertheless, management should deem it necessary to incorporate attitudes in management strategies. Periodic attitudinal surveys form baseline data for social impact assessments of conservation interventions.

1.3 Research Goal, Questions, and Hypotheses

The Western Terai harbors two of the most productive protected areas of Nepal: Royal Bardia National Park (RBNP) and Royal Suklaphanta Wildlife Reserve (RSWR). These areas are cornerstones for biodiversity conservation, but are under threats due to present political turmoil. Uncontrolled immigration, inefficient land reform policies, unsustainable resource use, and a dearth of research to provide data for sound policies are some pressing problems in the study area. The goal of the project is to assess resource use patterns and problems, and how they relate to conservation attitudes. This attitudinal 
survey will provide guidance for policy and management decisions involved in design, implementation, review, and monitoring of landscape level conservation in Nepal.

There are subtle differences between RBNP and RSWR. The buffer zone ( $328 \mathrm{sq} \mathrm{km}$ ) of RBNP was declared in 1996 and local people received $30-50 \%$ of revenue generated from the park since then. The buffer zone of RSWR was not officially declared. In RBNP, grassroots institutions were mandatory by conservation legislation while in RSWR they were instituted for convenience. There were many more non-governmental organizations working for conservation and sustainable development in the buffer zone of RBNP than RSWR. The status of RBNP is national park so tourism is promoted but that of RSWR is a wildlife reserve. RBNP is in rural setting while RSWR is closer to an urban area. Historically, ethic Tharus have used natural resources of these areas. The present day grasslands were created when people were evicted from the parks. Owing to these differences, I use a comparative study framework to meet the research goal. My research hypotheses are guided by the following questions:

Question 1. What are the demographic structures, socio-economic status, and ethnic composition of the study area?

Question 2. What are the types and patterns of natural resources extracted and used?

Question 3. How do resource use patterns and problems influence attitudes towards conservation? 
Question 4. To what extent can the distribution of benefits from access to the protected areas ensure the support of local communities for conservation objectives?

Question 5. Do conservation intervention programs solicit more favorable attitudes?

Question 6. To what extent are local institutions strengthened by conservation programs?

Based on primary data collected by household questionnaire surveys, I test the following hypotheses:

Hypothesis 1. The resource use patterns among caste/ethnic groups will be different.

Hypothesis 2. People participating in conservation intervention programs have more favorable attitudes towards conservation than others.

Hypothesis 3. The attitudes towards conservation differ among local people between two protected areas (RBNP and RSWR).

\section{THE STUDY AREA}

\subsection{Ecological Divisions}

Nepal is vertically stratified into three ecological regions: the Mountain, the Hills and the Terai. The Mountain region covers elevations between $4,877 \mathrm{~m}$ to $8,848 \mathrm{~m}$ above sea 
level. This region consists of a large number of magnificent peaks of the Himalayas that are sources of perennial rivers. The terrain is rough and inhospitable and the climate is harsh. It occupies about $35 \%$ of the total land area $(147,181 \mathrm{sq} \mathrm{km})$ of Nepal but harbors only $7.3 \%$ of the population. Livestock tending and seasonal businesses are the vocation of local people because only $2 \%$ of its land is suitable for cultivation. The Hill region lies between the elevations of $610 \mathrm{~m}$ to $4,877 \mathrm{~m}$ above sea level. Landscape diversity in medium sized peaks, fertile valleys and basins is characteristics. The region accounts the largest share $(42 \%)$ of the total area of which about one tenth of its area is suitable for cultivation. About $44.3 \%$ of total population resides in the region. The occupations of people include livestock rearing, cottage industries, and cultivation of cereal as well as cash crops. The Terai, being an extension of the Gangetic plains of India, forms a low flat land in the southern part of the country bordering India. It comprises $23 \%$ of the land area of the country and $48.4 \%$ of the total population. This area includes most agricultural land ( $40 \%$ is suitable for cultivation) and dense forest of the country. This region is also called the 'granary' of Nepal because fertile land with irrigation facilities permit the cultivation of a wide variety of crops such as paddy, wheat, maize, sugarcane, tobacco, and vegetables and two to three crops per year. The population of this region is increasing at a faster rate compared to the other two regions; due both to high birthrates and internal migration.

\subsection{Location}

The study area comprises two protected areas of the Nepalese Terai: Royal Bardia National Park (RBNP) and Royal Suklaphanta Wildlife Reserve (RSWR; Figure 2). The 
RBNP (81.46502 E and $28.44479 \mathrm{~N}$ ) lies in the mid-western Terai adjoining the eastern bank of the Karnali River in Bardia District. It was established in 1976 (originally), and is the largest protected area in the Nepalese Terai $(968 \mathrm{sq} \mathrm{km}$ and proposed extension of $550 \mathrm{sq} \mathrm{km})$. The RSWR ( $80.22640 \mathrm{E}$ and $28.84955 \mathrm{~N})$ is located in Kanchanpur District of far-western Terai along the southern border of Nepal. It was gazetted in 1973 and covers an area of $305 \mathrm{sq} \mathrm{km}$.

\subsection{Geology and Soils}

The Terai is the northern extension of Gangetic Plain. It is alluvial flood plain in the south and tertiary Siwalik in the north. The Siwalik is composed of coarsely bedded stone, crystalline rocks, clays and conglomerates. Soils are young and very shallow and are exposed to a great degree of erosion and landslide, with little potential for cultivation (HMG 1971). At the base of the Siwalik range is the 'Bhabar' zone, consisting of gravelley soil which has been washed down from the foothills and accumulated at their base. The Bhabar is not suitable for agriculture and large tracts of forests remain here. South of Bhabar is the Terai flatland, which consists of beds of silts, clay and gravel to great depths and is the most productive agriculture land in Nepal. Soils are predominantly brown or yellow brown sandy loams that are mostly calcareous and slightly alkaline (HMG 1971).

The soil is moreover sandy loam throughout the western Terai. The depth of soil is high in flat lands and low in the hills. Especially in degraded forests, the nitrogen content is 
poor. Big boulders are characteristic of soil of the Siwalik foothills. The elevation varies from $152 \mathrm{~m}$ in the Terai to $1441 \mathrm{~m}$ in the Churia (Siwalik) Range.

RSWR is drained by a number of rivers and streams, including the Mahakali, which demarcates the western boundary of Nepal with India, the Bauni, Chaudhara and Syali Rivers. Major wetlands within the reserve are located on the floodplains of these rivers. Eight oxbow lakes are found in the reserve (Sah 2002) of which Rani Tal (20 ha) and Kalikich Tal (10 ha) are large and famous. RBNP is drained by the Karnali and Babai Rivers, and there are many oxbow lakes within the park.

\subsection{Climate}

The region has a sub-tropical monsoonal climate with three distinct seasons: hot-dry (March-June), monsoon (July-October), and cold-dry (November-February). For the period 1987-2001, average monthly maximum and minimum temperatures of $38.3^{\circ} \mathrm{C}$ and $9.5{ }^{\circ} \mathrm{C}$ were recorded in May 1996 and January1989, respectively in RBNP (Figure 3). Likewise, average monthly maximum and minimum temperatures of $38.8^{\circ} \mathrm{C}$ and $6.0^{\circ} \mathrm{C}$ were recorded in May 1995 and January 1997, respectively in RSWR. The highest annual rainfall of $2798 \mathrm{~mm}$, and the lowest annual rainfall of $1592 \mathrm{~mm}$ occurred in the year 1990 and 1992 respectively in RBNP. In RSWR, the highest and the lowest annual rainfall of $2375 \mathrm{~mm}$ and $1257 \mathrm{~mm}$ occurred in the year 1998 and 1992, respectively. The highest mean monthly rainfall occurred in July $(680 \mathrm{~mm})$ in RBNP and in August $(635 \mathrm{~mm})$ in RSWR. The lowest mean monthly rainfall occurs in December $(21 \mathrm{~mm})$ in RBNP and in 
March (3 mm) in RSWR (Figure 4). The highest monthly rainfall of $945 \mathrm{~mm}$ occurred in July 1989 in RBNP, and of 1205 mm occurred in August 1995 in RSWR.

\subsection{Vegetation}

Dinerstein (1979) classified six major vegetation types in RBNP which were later modified by Jnawali and Wegge (1993) to seven major types:

- Sal Forest is characterized by Sal Shorea robusta and covers about $70 \%$ of the total area. The main associated species with Sal are Terminalia tomentosa and Buchanania latifolia.

- Khair-Sissoo Forest is a pioneer association on riverside gravel. This forest type is dominated by Khair Acacia catechu and Sissoo Dalbergia sissoo. Two shrub species, Murraya koenigii and Callicarpa macrophylla form dense under-stories.

- Moist Riverine Forest is distributed in patches along water courses and in depressions. This forest is characterized by evergreen species such as Syzigium cumini, Mallotus philippinensis, Ficus racemosa and Bombax ceiba.

- Mixed Hardwood Forests grow in well drained flat land. Adina cordifolia, Casearia tomentosa, Garuga pinnata, Mitragyna parviflora are some common tree species of this forest type.

- Wooded Grasslands are grass-covered areas with sparsely distributed trees. Imperata cylindrica, Saccharum spontaneum, Vetiveria zizanoides, Cyperus kyllingia are the most common grasses. Tree species such as Bombax ceiba, Adina cordifolia, Bahunia malbarica and Mallotus philippinesis are also sparsely distributed in this habitat. 
- Phanta is short open grassland in previously cultivated fields. Imperata cylindrica is the dominating grass species in this vegetation type.

- Flooded Grasslands are tall grasslands along floodplains. The dominant species are Saccharum spontaneum, S. bengalensis, Phragmatis karka and Narenga phorphyrocoma.

The vegetation of RSWR consists of forests, grasslands and wetlands. Sah (2002) classified forests into three types. Riverine Forest on the banks of rivers and streams are dominated by Acacia catechu and Dalbergia sissoo. In Mixed Deciduous Forest, there is an assemblage of species such as Adina cordifolia, Celtis tetrandra, Mallotus philippinensis, Syzygium cumini, and Trewia nudiflora. Sal Forest is found in relatively well-drained uplands. The species composition of the forest is Shorea robusta, Lagestroemia parviflora, Terminalia belerica and Terminalia chebula.

RSWR is famous for the most extensive tracts of grasslands within the protected areas network of Nepal. Suklaphanta is the largest grassland which covers an area of $54 \mathrm{sq} \mathrm{km}$. Imperata cylindrica, Saccharum bengalensis, Saccharum spontaneum, Narenga porphyrocoma, and Desmostachya bipinata are the dominant species of this grassland.

\subsection{Wildlife}

The main objective of the establishment and management of both RBNP and RSWR was to conserve critical habitats for globally endangered Bengal tiger and its prey species. The RSWR boasts the largest density of the tiger (Regmi 2000) and RBNP has a breeding 
population of 35-40 individuals (DNPWC 2003). The RBNP harbors a known total of 53 species of mammals, ca 400 species of birds, 25 species of reptiles and amphibians and 121 species of fishes (DNPWC 2003). Likewise about 43 mammals and 268 birds have been documented so far in RSWR (DNPWC 2005). These protected areas are important habitats for charismatic megafauna such as Bengal tiger, Asian elephant, and reintroduced one-horned rhinoceros. Probably the largest herd of Barasingha Cervus duvauceli in the wild thrives in RSWR and it has the largest population of the endangered Bengal Florican Houbaropsis bengalensis (Baral et al. 2003).

\subsection{Settlements}

The buffer zone of RBNP (328 sq km) was declared in 1996 in the west and south. It includes 17 village development committees and some 120,000 people live in 11,504 households within it. The buffer zone of RSWR has not been officially declared yet, but conservation and development activities have been carried out in the proposed buffer zones (Heinen \& Rayamajhi 2001).

\subsection{Ethnographies}

The founding King of modern Nepal, Prithvi Narayan Shah, described ethnic heterogeneity as 'char jat and chattis varna' [garden for all types of people] which was later misconstrued in the Civil Code of 1854. The code classified people into three classes: higher castes, touchables and untouchables. Discrimination based on religion, race, sex, caste or ideology was theoretically abolished by the constitution of 1961 and 
the new Civil Code also ended the practice of punishing offenders based on their caste (Karki \& Bhattarai 2004).

Nepal is a multiethnic, multilingual and a predominantly Hindu state. Although it is a non-secular state, the practice of other religions is common. About $81 \%$ of the population are Hindus followed by Buddhists (10.7\%) and Muslims (4.2\%; CBS 2001). The Kirat, Jain, Christian, Sikh and Bahai religions are all also practiced in Nepal. There was no systematic record keeping of ethnic groups in the past national censuses. For the first time, an attempt was made to collect various data based on ethnicity in the 2001 national census. According to that census, there are 102 caste/ethnic groups speaking 92 dialects (CBS 2001). There is a distinct pattern of geographical distribution of caste/ethnic groups in Nepal. People of Tibetan origin are in the high Himalayas, Hindu caste people (Brahman, Chhetri and Occupational castes) are in middle hill regions and ethnic Tharu are in the lowlands.

Tharus are probably the oldest inhabitant of the Terai region. They are considered indigenous because it is believed that they have lived there for more than 600 years (Cox 1990). Tharus are an aboriginal tribe found in Nepal and India, but large numbers of Tharus reside in Nepal (Verma 1998). Tharus are found in scattered settlements in the proximity of forests of the Terai from the Koshi River in the east to the Mahakali River in the west. There are several hypotheses regarding the origin of Tharus. Some authors trace their origin to Rajput ancestors who fled the battle described in the epic Mahabharat while others believe that they fled to northern frontiers in the time of the Islamic 
invasions in India. Some Tharus claim that they are descendants of Rajput women who fled with domestic servants. Although the origin of Tharus is a controversial issue, present day scholars reject the claim that they are from Rajasthan. Tharus are a Mongoloid tribe who have successfully assimilated non-Mongoloid physical features as well (Bista 1987).

There is no caste-hierarchy among Tharus; Tharus have 32 groups and no group is considered privileged (Bista 1987; Verma 1998). Rana Tharus are isolated among groups and live in Kailali and Kanchanpur Districts while other groups are scattered in the eastern and western lowlands. In the past, Tharu villages were found in enclaves of dense forests and wildlife (Bista 1987). This is not the typical case at present due to shrinking forest cover. They still prefer to live in the proximity of forested areas. They are peasant farmers (Bista 1987; Verma 1998) who keep different types of livestock and who practiced shifting agriculture in the past.

The solidarity among members of Tharu tribe is appreciable. In spite of the modern sociopolitical system, they have their traditional system of leadership known as 'budghar'. This is one of the most democratic systems in a tribal society. Members of a tribe elect a village head - the budghar, and render services until he quits or villagers oust him for inefficiency. The budghar, in consultation with elders, settles social disputes and impose fines to defaulters. The fine is pooled in a village trust fund and used for collective causes. The trust, solidarity, traditional institutions and graduated sanctions all 
have harnessed social capital (Krishna 2002). However, this capital is not yet tapped for socioeconomic development of Tharus in the modern era.

Most Tharus live in joint family structures, and in some cases, in extended familes. There is an explicit hierarchy, division of labor, and functional roles of members living in joint and extended families. Tharus are quickly emulating cultural practices of other groups and opting for nuclear families nowadays. Arranged marriages, working for a wife and elopement are common modes of acquiring mates (Bista 1987). Marriage is within the tribe, but not within one's 'gotra' (clan). In India, marriages are solemnized according to the Hindu calendar (Jain 1991). The institution of marriage is sacred, patrilocal and monogamous. Tharu women used to have a superiority complex to their male counterparts, but this is now ending abruptly (Verma 1998). Among ethic groups, Tharus keep their houses exceptionally clean and are connoisseurs of folk art. They have a great deal of knowledge on color and pattern choices for painting, knitting and clay work. Throughout their population, the literacy rate among Tharu is very low (Bista 1987; Jain 1991).

Tharus have their own tribal religion and worship a number of local spirits and personal deities (Bista 1987). They have also incorporated Hindu deities into their rituals. Tharus who have been following their traditional religion have their own priests called 'guruva'. Some Tharus call Hindu priest to perform weddings and other domestic ceremonies. In India, Tharus demanded Hindu caste status based on similarities in ceremonies of marriage and shradh (a ritual performed to pacify the departed soul; Verma 1998). Tharus 
are undergoing tremendous changes due to cultural invasion (Bista 1987; Verma 1998). They are gradually reforming food habits, religious practices, cultural values, and adopting modern education. These cultural changes will likely have impacts on natural resource conservation and management.

\section{MATERIALS AND METHODS}

\subsection{Selection of Villages}

I selected 14 settlements of two village development committees of RBNP, and 15 settlements of six wards of RSWR. As per the Buffer Zone Management Regulation of 1996, the park authority formed User Groups (UGs) at the village (hamlet) level. An adult representative from each household from the village get together and select their representatives for the UG. I chose UGs as sampling units. The rationale for selecting these settlements are, (i) they lie within declared or proposed buffer zones, (ii) some integrated conservation and sustainable development programs have been implemented in these areas, (iii) they are politically more stable, and (iv) they are easily accessible.

\subsection{Household Survey}

3.2.1 Household survey team: The survey team consisted of myself and one local high school graduate belonging to the ethnic Tharu community. Whenever Tharu respondents preferred to answer in their mother tongue, the research assistant translated their answers into the Nepali language for me. Since I administered all household interviews, personal biases were not a problem. 
3.2.2 Survey instrument: Heinen (1993) developed a survey protocol to study park people interactions in Koshi Tappu Wildlife Reserve, Nepal. This protocol was later modified and used by Sah (2002) and Shrivastava (2002) to study socioeconomic dynamics of protected areas of Nepal and India, respectively. I slightly modify the protocol to meet my objectives and to adjust to local sociopolitical conditions. As the protocol was reliable, I did not pre-test for validation.

3.2.3 Survey procedure: Prior to data collection, a research proposal and draft survey forms were reviewed and approved by the Institutional Review Board on Human Subjects, Florida International University, Miami, USA. Permission to conduct surveys in the buffer zones of protected areas was obtained from the Department of National Parks and Wildlife Conservation, Nepal. In the field, the survey team visited each respondent in his/her house. The respondents were briefed about the purpose of the visit and verbal consent was taken to participate in interviews voluntarily. The questionnaire was written in Nepali [the official or national language of Nepal] and administered orally. The average time required to complete one interview was about 30-45 minutes.

The geographical position of each household was taken with GPS. Spatial reference and socioeconomic data were fed into the GIS system. Maps of the study area were derived from the input data. 


\subsection{Sample Size and Sampling}

From the archive of the UGs, I stratified the sample households by ethnicity (caste groups). A structured questionnaire survey was administered to a sample of 234 randomly selected households living in the buffer zones of RBNP and RSWR from February to May of 2004. Taking into account the high illiteracy rate in rural Nepal, questionnaires were written in the Nepali language, but were asked in Nepali or Tharu, depending on the ethnicity of household being surveyed. Local words were used and technical jargon was avoided. One adult person (19 years old or above) in each household was interviewed in his/her residence. Usually, household heads (generally male) were interviewed; in their absence, any member willing to participate was interviewed resulting in more male (186) than female (48) respondents. Each questionnaire was divided into seven general parts: (1) ethno-religious background, household characteristics (gender, age and occupation of all household members), education (illiterate, primary, secondary and college), and migration status; (2) economic activities such as land-holdings, alternative sources of income, annual cash income, (3) agriculture and animal husbandry; (4) natural resources use; (5) conservation awareness; (6) participation and benefits (memberships, personal benefits, income generating activities and saving-credit program), and (7) assessment of satisfaction towards UGs and wildlife conservation issues. Most of the questions were closed-ended, although some open-ended contingency questions were also included. A sample of survey protocol is appended (Appendix 2). 


\subsection{Survey of User Groups (UGs)}

The chair of 14 UGs of RBNP and 15 UGs of RSWR were also interviewed. They were asked about group formation, frequency of meetings, policies on non-timber forest products and their marketing, distribution of benefits, and attitudes towards the Terai Arc Landscape project and conservation legislation. Whenever I had an opportunity, I also did content analysis of operational plans, five-year work plans, and annual reports of UGs.

\subsection{Survey Limitations and Constraints}

Due to the Maoist insurgency in the region rural people were reluctant whenever we visited them. Although we had explicitly explained our purpose and they were willing to be interviewed, they were frequently wary. Taking into account the sensitive political situation, we did not cross-examine responses on land holdings and household incomes. In some cases, neighbors of respondents gathered out of curiosity, which is normal in rural areas, and gave suggestions to respondents being interviewed. Therefore, some issues reflected collective perception rather than personal opinion. Women were more hesitant than men to be interviewed. Among many ethno-religious groups, women have less power in decision-making. As per social customs, it is not feasible to interview females when males are present at home. This had resulted in the asymmetrical representation of gender. These limitations and constraints may influence interpretation of results. 


\subsection{Statistical Analyses}

Before processing data, they were entered in Microsoft Excel. All questionnaires were scrutinized to detect errors and omissions. Accurate data that were consistent with other facts were included for coding and tabulation. Attribute data such as gender, caste, occupation, literacy were assigned numerals. To facilitate analysis, some quantitative data were converted into categorical data. From MS Excel data were imported to STATA Version 8 and analyzed.

For conservation attitudes, a series of statements was presented and respondents were asked to agree or disagree. Statements covered broad conservation issues such as the status of forests, custodianship of resources, perceptions of open access resources, wildlife populations and depredation, socioeconomic improvements, access to resources, intra and intergenerational equity, existence of parks, and willingness to contribute to conservation were included. If the respondent agreed with the statement one point was given, otherwise no point was given. The reverse was true for a negative statement. The scores of all statements were summed to derive an attitude score that could theoretically range from 0 to 11 . The higher the attitude score, the more favorable attitude the respondent had towards conservation.

There were eight types of resources harvested by respondents in RBNP and seven types in RSWR. At first, harvest frequency of each type of resource was calculated. Based on the harvest frequency, resources were assigned importance values. In case of RBNP, the weight of the eight to one score was applied in descending order; eight was assigned to 
the resource having the highest frequency. Similarly, in RSWR the weight of the seven to one score was applied in descending order; seven was given to the resource having the highest frequency. The weighted scores of types of resources harvested in a household were summed to calculate a resource use score that could theoretically range from 0 to 36 in case of RBNP and 0 to 28 in case of RSWR. The higher the score, the more dependent were respondents on resources. Based on an equal interval, the resource use score was categorized into four categories: not dependent, somewhat dependent, dependent, and most dependent. Frequency-based 'importance' assignment may not truly reflect the impacts of resource use or scarcity of resources, I used it in my analysis for convenience.

Since my analytic framework is a comparative study between two protected areas, I used a parametric two-sample $t$ test when quantitative data were normally distributed and the non-parametric Mann-Whitney test when they were not, to estimate the difference between certain variables of the two independent samples. Means of quantitative variables were presented with one standard deviation.

The Kruskal-Wallis One-Way Analysis of Variance by Ranks was used to test for differences in family size and landholdings among four groups of respondents (Tharus versus non-Tharus and RBNP versus RSWR). The chi-square test of independence was used for testing associations between qualitative variables. The null hypothesis is that the two variables are not related. To measure a relationship between resource use score and quantitative socioeconomic variables, Spearman's rank correlation coefficient (Rho) was used. 
To see the effects of two or more independent variables on a single dependent variable, multiple regression is an appropriate statistical method (see Allison 1998 for an introduction to this technique). I built a regression model taking the conservation attitude score as a dependent variable; and demographic, socioeconomic and benefit variables, and resource use score as independent variables. All categorical independent variables in the model were recorded as dummy variables, each with two categories: 'yes' and 'no'.

\section{RESULTS}

\subsection{Demographic Characteristics of Respondents}

4.1.1 Gender and age: Of 234 respondents, $79 \%$ were male and $21 \%$ were female. There was no significant difference in the proportion of male and female respondents between two protected areas $\left(\chi_{1}^{2}=1.40, \mathrm{p}=0.237\right)$. In RBNP, $82 \%$ of respondents were male and $18 \%$ were female while in RSWR $76 \%$ were male and $24 \%$ were female (Figure 5 ).

The range of respondents' age was 19 to 75 years. The mean age of respondents of RBNP $(41.51 \pm 12.31$ years $)$ was not significantly different from RSWR $(41.67 \pm 13.09$ years; $t$ $=-0.10, p=0.925)$. The mean age of male $(41.80 \pm 12.16)$ and female $(40.14 \pm 13.18)$ respondents was not significantly different in RBNP $(t=-0.58, p=0.566)$. However, in RSWR the mean age of male respondents ( $44.02 \pm 13.24$ years) was significantly higher than the mean age of female respondents $(34.15 \pm 9.43$ years; $t=3.53, p=0.0006)$. 
4.1.2 Ethnicity: Although discrimination based on caste and ethnicity was abolished by law, it is practiced socially. Brahman and Chhetri rank high and Occupational castes (cobbler, ironsmith, tailors etc.) rank low in the Hindu caste hierarchy. Tharus are indigenous people of Terai and Hill tribes include ethnic groups of mountain origin such as Gurung, Magar and Newar.

There was a significant difference in ethnic composition of respondents between the two areas $\left(\chi_{4}^{2}=48.85, \mathrm{p}=0.000\right)$. In RBNP, more than half $(51 \%)$ were Tharu followed by Chhetri (21\%), Brahman (18\%), Occupational castes $(6 \%)$ and Hill tribes $(3 \%)$. In RSWR, the proportion of Chhetri (45\%) was highest followed by Brahman (27\%), Occupational castes $(17 \%)$, Tharu $(10 \%)$ and Hill tribes (2\%; Table 1$)$.

4.1.3 Education: The education level of respondents was categorized into five groups. Respondents who did not know how to read and write were classified as 'illiterate' and those who could read or write but had no formal education were 'literate'. Respondents who had 1 to 5 years of formal education fall into 'primary', those who had 6 to 10 years of formal education belonged to 'secondary'. Those who had an associate degree or above were classified as 'college'.

There was a significant association between the level of education and protected areas $\left(\chi_{4}^{2}=18.14, p=0.001\right)$. About $38 \%$ were illiterate and $22 \%$ were literate in RBNP while $24 \%$ were illiterate and $17 \%$ were literate in RSWR. In RBNP, $19 \%, 18 \%$ and $2 \%$ had primary, secondary, and college level education respectively while in RSWR, 15\%, 39\% 
and $14 \%$ had primary, secondary and college level education respectively (Table 2 ). The ethnic categories of Brahman, Chhetri, Occupational castes and Hill tribes were merged into one category (non- Tharu) to compare differences in education level. Ethnicity was significantly associated with level of education $\left(\chi^{2}{ }_{4}=19.04, p=0.001\right)$. The illiteracy rate among Tharus (36\%) was significantly higher than non-Tharus $(29 \%)$. Among Tharus, $29 \%$ were literate, $21 \%$ had primary, $12 \%$ secondary, and $1 \%$ had a college level education. Non-Tharus were better off than Tharus in level of education. Among nonTharus, $16 \%$ were literate, $15 \%$ had primary, $30 \%$ secondary, and $11 \%$ had a college level education. The literacy rate among women $(40 \%)$ was significantly lower than men $\left(76 \% ; \chi_{4}^{2}=25.20, p=0.000\right)$.

4.1.4 Occupation: 'Agriculture' is the primary vocation of most respondents. Paddy, lentil and wheat are staple crops. In addition to subsistence agriculture, people are also engaged in other vocations. Service oriented activities in public, private and military sectors as well as teaching were included in one category 'job'. Seasonal wage labor and other non-farm income generating activities were categorized as 'menial work'. The respondents who were involved in trade and business at the local level were categorized as 'business'. 'Students' were those who were currently enrolled in formal education.

About $77 \%$ of respondents were subsistence farmers while $23 \%$ were engaged in some off-farm activities. There was a significant difference in the proportion of respondents practicing subsistence agriculture and non-farm activities between two areas $\left(\chi_{1}^{2}=18.55\right.$, $\mathrm{p}=0.000)$. In RBNP, $88 \%$ and $12 \%$ respondents reported agriculture and off-farm 
activities respectively as their primary vocation. In RSWR, $64 \%$ and $36 \%$ respondents reported agriculture and off-farm activities respectively as their primary vocation. The off-farm occupations in RBNP were job (6\%), menial work (6\%) and business $(2 \%)$, and in RSWR they were job (17\%), menial work $(5 \%)$, business $(7 \%)$ and student $(6 \%$; Figure 6). The ethnic category was also significantly associated with occupation $\left(\chi_{1}^{2}=\right.$ $9.58, \mathrm{p}=0.002)$. Most Tharus $(89 \%)$ were subsistence farmers while $11 \%$ were engaged in off-farm activities. Among non-Tharus, $71 \%$ were subsistence farmers while $29 \%$ were involved in non-farm activities.

4.1.5 Family size: The average family size of RBNP was not significantly different from that of RSWR $(z=-1.03, p=0.305)$. The mean family size of RBNP was $7.63 \pm 4.60$ and varied greatly from two to 32 members. In RSWR, the mean family size was $7.64 \pm 3.44$ and varied from one to 23 members.

The Kruskal-Wallis one-way analysis of variance by rank showed that mean family size of Tharus and non-Tharus was significantly different in the two areas $\left(\chi^{2}{ }_{3}=17.46, p=\right.$ 0.001). The Bonferroni procedure of multiple comparisons showed that the family size of Tharus of RBNP $(9.23 \pm 5.75)$ was larger than that of non-Tharus of RBNP $(5.95 \pm 1.85$; $z=-3.87, p=0.000 ;$ Table 3 ). There was no significant difference in family size of other pairs $(\mathrm{p}>0.10)$. The Kruskal-Wallis test also showed that there was no significant association between family size and level of education $\left(\chi_{4}^{2}=2.61, \mathrm{p}=0.625\right)$. 


\subsection{Migration and Economic Status}

Tharus are the only indigenous tribe in the study area. All other ethnic groups or castes migrated to the Terai, mostly from the Mountain. There is some internal migration of Tharus within the Terai.

There was a significant difference in the proportion of immigrants and residents between the two areas $\left(\chi_{1}^{2}=28.25, \mathrm{p}=0.000\right)$. Almost all $(96 \%)$ respondents had migrated while only $4 \%$ were resident people in RSWR. In RBNP, $70 \%$ of respondents had migrated while $30 \%$ were resident (Table 4). Migration into these places is vertical (hills to plain) as well as horizontal (east - west). More than half (55\%) and about two thirds (74\%) of respondents of RBNP and RSWR, respectively, had migrated to the study area from mountain districts. Likewise, $25 \%, 16 \%$ and $3 \%$ of respondents migrated to RBNP from other Terai districts, villages within the district and other places, respectively. In RSWR, $21 \%$ migrated from villages within the district and $5 \%$ from other places. The mean years of duration of residency of migrants was not significantly different between RBNP and RSWR $(z=-0.60, p=0.549)$. It was $23.37 \pm 11.37$ years for RBNP and $23.85 \pm 10.50$ years for RSWR. People started immigrating some 46 years ago in RBNP and 44 years ago in RSWR and the trend is continuing. The reasons given by respondents $(\mathrm{N}=183)$ for migration were insufficiency of fertile land $(39 \%)$, landlessness $(8 \%)$, government programs $(12 \%)$, unemployment $(3 \%)$, and social factors $(37 \%)$ such as to be close to relatives, more physical and infrastructural facilities and access to resources. 
There was no significant difference in mean landholdings between the two areas $(\mathrm{z}=$ $0.80, \mathrm{p}=0.422$ ). The mean landholding of RBNP was $0.687 \pm 0.67$ ha and ranged from 0.03 ha to 3.15 ha. Likewise, the mean landholdings of RSWR was $0.714 \pm 0.67$ ha and ranged from 0.03 ha to 4.74 ha. The Kruskal-Wallis one-way analysis of variance by rank among four groups showed that there was no significant difference in landholdings $\left(\chi_{3}^{2}=\right.$ $2.50, \mathrm{p}=0.271)$. Although Tharus of RSWR had slightly more land than the other three groups, this was not statistically significant ( $p>0.05$; Table 5).

Landholding was classified into three groups: small, medium and large, following government standard criteria. Small holders have less than 0.5 ha of land, medium holders have 0.5 ha to 2 ha of land and large holders have more than 2 ha of land (CBS 1992). There was no significant association of land categories with area $\left(\chi^{2}{ }_{2}=3.70, p=\right.$ 0.157). In RBNP, 53\%, 40\% and 7\% belonged to small, medium and large landholders, respectively. Similarly, $45 \%, 51 \%$ and $4 \%$ belonged to small, medium and large landholders, respectively, in RSWR.

One encouraging finding was that $87 \%$ of respondents had land tenure, and only $13 \%$ did not, but were using lands without title. There was no significant difference in the proportion of respondents with unregistered lands between the two areas $\left(\chi^{2}=0.11, p=\right.$ 0.743 ). Fourteen percent of RBNP and $12 \%$ of RSWR respondents did not have tenured lands. 
There was a significant association of agricultural yield with area $\left(\chi_{1}^{2}=27.52, p=\right.$ 0.000 ). About $73 \%$ of respondents of RSWR mentioned that they had enough produce from their farms to sustain, but $61 \%$ of respondents of RBNP said that they did not meet their annual ration of staple food from their farms (Table 6). Of those who did not have enough yield from their agricultural lands, on average they had to buy staple foods for $6.21 \pm 3.05$ months per year $(\mathrm{N}=105)$.

I asked respondents how much they earn in a year from non-farm activities. Of 234 respondents, $86 \%$ responded to the question. The annual cash income is highly skewed with a range of US $\$ 28^{1}$ to US\$ 2366 and an average of $544 \pm 476$ US dollars. There was a significant difference in annual cash income of respondents in the two areas $(z=-2.94$, $p=0.0032$ ). The average annual cash income of RSWR was US\$ $664 \pm 544$ (range US\$ 28 - 2366), which was larger than the average income of USS $444 \pm 386$ (range US\$ 28 1894) of RBNP respondents.

Cattle, buffalo, goat/sheep, pig and poultry were common types of livestock in these areas. The overwhelming number of respondents $(96.2 \%)$ had one or more kinds of livestock. As the values of different livestock and their impacts on natural resources vary, the number of livestock per household was expressed using the Livestock Size Unit (LSU). Since a $400 \mathrm{~kg}$ steer is equivalent to $1 \mathrm{LSU}$ (Raut 1997), in the present study, 1 adult buffalo (1 LSU) was considered equivalent to 1 steer, and one immature buffalo, cow, calf, pig, and sheep or goat was equivalent to $0.5,0.8,0.4,0.3$ and 0.2 steer,

\footnotetext{
${ }^{1} 1$ US $\$=$ NRs 71 in 2004
} 
respectively. Poultry were not included in LSU calculation. There was no significant difference in LSU between the two areas $(z=-0.44, p=0.656$; Table 7). In RBNP, the average LSU was $4.37 \pm 4.76$, which ranged from 0.2 to 44 . In RSWR, the average LSU was $3.97 \pm 2.11$ and ranged from 0.4 to 11 . In RBNP, $54.4 \%$ rear water buffalo, $65.6 \%$ cattle, $57.6 \%$ sheep and goat, and $41.6 \%$ pig (Figure 9). In RSWR, $68.8 \%$ rear water buffalo, $91.7 \%$ cattle, $25.7 \%$ sheep and goat, and $2.7 \%$ pig. People of RBNP tend to keep larger numbers of buffalo $(z=3.13, p=0.0017)$ and sheep/goat $(z=2.66, p=0.0078)$ than people of RSWR. There was no significant difference in numbers of cattle $(z=1.03$, $\mathrm{p}=0.301)$ and pig $(\mathrm{z}=1.26, \mathrm{p}=0.2066)$ between these areas. Kruskal-Wallis one way analysis of variance by rank showed that there was no significant difference in mean LSU among the four groups (Tharu versus non-Tharu and RBNP versus RSWR; $\chi^{2}{ }_{3}=2.51, p$ $=0.474)$.

\subsection{Resource Use Patterns and Dependency}

Firewood is the main source of energy in the study area. Local people use thatch as roofing material and grasses and fodder for livestock feed. Honey, mushrooms, fruits, vegetables are supplementary to staple diet. Local people ferment home brewed liquor with herbs and use timber for house construction and furniture. Green leaves are used to make leaf plates and in religious ceremonies. Dry leaves are harvested to use as bedding material for livestock and which is later on composted. The park authority provides permit to collect thatch once a year inside the parks and reserves. However, in buffer zones local people are allowed to collect any sort of resources as stipulated in the operational plan. Eight types of natural resources were extracted from the park and buffer 
zone forests of RBNP while seven types were extracted from the reserve in RSWR. Local people in RSWR did not collect timber from the reserve, while local people in RBNP collected timber from the buffer zone. In RBNP, 93\% households collected thatch followed by firewood $(68 \%)$, leaf litter $(62 \%)$, grasses $(52 \%)$, edible plants $(42 \%)$, timber $(41 \%)$, tree fodder $(20 \%)$ and herbs (15\%). In RSWR, $78 \%$ of household collected thatch followed by firewood $(58 \%)$, grasses $(44 \%)$, leaf litter $(34 \%)$, edible plants $(10 \%)$, tree fodder $(2 \%)$ and herbs (1\%). Significantly, more households in RBNP extracted thatch, leaf litter, edible plants, tree fodder and herbs in comparison to RSWR ( $p<0.05$; Table 8). Various types of resource uses have different impacts on natural resource conservation and management.

The nonparametric correlation of continuous variables with the resource use score showed that there was a significant negative correlation between the resource use score and annual cash income $(\mathrm{p}=0.0001)$, and a positive correlation between the resource use score and recency of arrival $(\mathrm{p}=0.000)$. Family size and LSU were positively correlated with the resource use score at a $10 \%$ error level (Table 9). The correlation between landholdings and resource use score was negative, but not significant.

The resource use score was categorized into four: not dependent, somewhat dependent, dependent and most dependent, based on equal intervals. There was a significant association of resource dependency of local people between the two protected areas $\left(\chi_{3}^{2}=\right.$ 35.62, $\mathrm{p}=0.000$; Table 10). In RBNP, $23 \%$ belonged to most dependent, $50 \%$ to dependent, $21 \%$ to somewhat dependent, and only $6 \%$ to not dependent. In RSWR, $8 \%$ 
belonged to most dependent, $28 \%$ to dependent, $39 \%$ to somewhat dependent, and $24 \%$ to not dependent. The dependency on resources was also significantly associated with ethnicity $\left(\chi_{3}^{2}=43.24, p=0.000\right)$. Among Tharus, $57 \%$ and $29 \%$ of respondents belonged to dependent and most dependent categories, respectively while $32 \%$ and $10 \%$ of nonTharus belonged to those groups, respectively.

There was a significant association between resource use patterns and ethnicity $\left(\chi_{1}^{2}=\right.$ 77.93, $\mathrm{p}=0.000)$. Most Tharus $(95 \%)$ collected green leaves for religious and social functions, but a few (5\%) collected dry leaf litter from forests to use as bedding material for livestock. Conversely, non-Tharus most often ( $88 \%$ ) collected dry leaf litter to use as bedding material which is subsequently used in agriculture to enrich soil fertility, while only $12 \%$ of respondents collected green leaves for making leaf plates.

There was a significant association between types of leaves collected and area $\left(\chi_{1}^{2}=\right.$ 47.13, $\mathrm{p}=0.000$ ). In RBNP, $74 \%$ of household collected green leaves from the park and buffer zone forests while $95 \%$ of households collected dry leaf litter from the reserve in RSWR. People of RBNP collected more firewood than people of RSWR ( $z=4.57, p=$ $0.0000)$. The reported average amount of firewood collected per household in RBNP (951 $\pm 1143 \mathrm{~kg}$ per year) was more than double the amount collected per household (332 \pm $366 \mathrm{~kg}$ per year) in RSWR. Local people also collected more thatch from RBNP than from RSWR $(z=3.79, p=0.0001)$. About $41 \%$ of respondents of RBNP harvested timber from buffer zone forests but none of the respondents from RSWR reported using 
timber from the reserve. The average quantity of timber harvested per household from buffer zone forests was $9.90 \pm 10.95$ cubic feet $(\mathrm{N}=51)$.

One of the most important aspects of natural resource use is the methods of gathering feed for livestock. There was a significant difference in the practice of livestock grazing between the two areas $\left(\chi_{2}^{2}=23.42, p=0.000\right)$. About $64 \%$ of households stall fed their livestock in RBNP while $85 \%$ of households stall fed their livestock in RSWR. In RBNP, $28 \%$ and $8 \%$ of households grazed livestock in community pastures and forests, respectively. In RSWR, $4 \%$ and $11 \%$ households grazed livestock in community pastures and forests respectively (Table 11).

There was a significant association of source of livestock feed between two areas $\left(\chi_{1}^{2}=\right.$ $5.52, \mathrm{p}=0.019)$. In comparison to RBNP $(73 \%)$, more households $(86 \%)$ in RSWR met their fodder requirement from private lands. More households $(27 \%)$ in RBNP than in RSWR (14\%) collected fodder from the park and buffer zone forests (Table 12).

In both areas, the proportion of respondents mentioning the problem of getting adequate resources such as firewood was not significantly different $\left(\chi_{1}^{2}=2.38, p=0.123\right)$. In RBNP, $68 \%$ of households mentioned the problem of firewood while in RSWR $72 \%$ of households mentioned the problem. This is because there was no significant difference in the sources of household energy between two areas $\left(\chi_{2}^{2}=0.02, p=0.991\right)$. Significantly, a high proportion of households $(90 \%)$ in both areas still rely on traditional inefficient mud stoves to cook. Smaller proportions of households either used improved mud stoves 
(4\%) or relied on alternative energy sources $(6 \%)$ such as kerosene, liquefied petroleum gas and biogas (Table 13).

There was a significant association of suggestions regarding the firewood problem with area $\left(\chi_{4}^{2}=35.98, \mathrm{p}=0.000\right)$. Only $20 \%$ of respondents of RBNP suggested issuing permits for firewood collection from inside the park while more than half of respondents $(55 \%)$ of RSWR were of opinion that the reserve should be open for firewood collection with permit. Higher proportions of respondents (34\%) of RBNP were suggesting the introduction of alternative energy sources (especially biogas) than of RSWR (21\%). More respondents of RSWR (15\%) were in favor of private plantations than RBNP (7\%; Table 14).

There was a significant association of local trade of natural resources with area $\left(\chi^{2}\right)=$ $10.74, p=0.001)$. In RBNP, $40 \%$ of households mentioned that they have engaged in buying or selling resources, while in RSWR only $20 \%$ of households mentioned that they were involved in such activities. About $80 \%$ and $60 \%$ of households in RSWR and RBNP, respectively were not engaged in local trade of natural resources within their villages.

There was significant association of interest in non-timber forest product (NTFP) farming with area $\left(\chi_{1}^{2}=8.34, p=0.004\right)$. In RBNP, only $34 \%$ households showed interest in NTFP farming while $66 \%$ did not show any interest. In RSWR, $52 \%$ households showed interest while $48 \%$ did not show any interest. 


\subsection{Participation in Conservation}

People's participation is a widely used phrase in the conservation lexicon. After the promulgation of a participatory approach, most institutions dealing with resource management and conservation have devised mechanisms for public participation. In theory, local people are empowered and local institutions are harnessed for sustainable management of natural resources through active participation. With the promulgation of community-based conservation legislations, grassroots institutions have emerged in the conservation areas and buffer zones. Local people are general member of these institutions and among them a few are executive members. NGO sponsored trainings were provided to local people to raise their standard of living and to executive members to strengthen the grassroots institutions. NGOs have also initiated income-generating activities such as goat raising, NTFP farming, piggery, sewing-cutting for local communities. Local people got personal benefits such as biogas plant, drinking water, toilet, piglets etc. from NGOs implementing integrated conservation and development programs. In Saving-Credit program local people form a group and deposit a fixed amount of money per week or month and lend that money to a member of the group to undertake income-generating activities. The creditor pays a nominal interest per month. This is more like a rural bank. All above programs are taken as conservation interventions by NGOs. I used these programs to measure popular participation of local people in conservation.

Significantly more households of RBNP (29\%) were members of one of the grassroots institutions than households ( $13 \%)$ of $\operatorname{RSWR}\left(\chi_{1}^{2}=8.82, \mathrm{p}=0.003\right)$. More households of 
RBNP $(35 \%)$ received some sort of training than those of RSWR $\left(19 \% ; \chi_{1}^{2}=7.36, p=\right.$ 0.007). More households got direct benefits from conservation interventions in RBNP $(36 \%)$ than in RSWR $(10 \%)$, which was also statistically significant $\left(\chi_{1}^{2}=21.47, \mathrm{p}=\right.$ 0.000 ). At $10 \%$ error level, the saving-credit program of RSWR was more pronounced than that of RBNP $\left(\chi_{1}^{2}=3.75, p=0.053\right)$. About $66 \%$ of households were participating in the program in RSWR while only $54 \%$ households of RBNP were in the program. Households of RSWR were depositing more money in the saving-credit program than those of RBNP $(z=3.00, p=0.0027)$. Households of RSWR deposited on average US\$ $0.45 \pm 0.32$ (range $0.07-2.82$ ) per month in saving-credit while households of RBNP deposited on average US\$ $0.34 \pm 0.42$ per month (range $0.07-1.41$ ). Significantly, a higher proportion of households (18\%) of RBNP were involved in income generating activities in comparison to households $(5 \%)$ of $\operatorname{RSWR}\left(\chi_{1}^{2}=9.66, \mathrm{p}=0.002\right.$; Table 15).

\subsection{Conservation Attitudes}

Five attitude statements were significantly different while six were not significantly different between the two protected areas (Table 16). The statements that differed between the two areas were: perception on forest status, custodianships of resources, trends in wildlife populations, socioeconomic upliftment, and resource use conflicts. The statements that did not differ were: problems with open access, anthropocentric views, existence of protected areas, intergenerational equity, intragenerational equity, and willingness to contribute for conservation causes. 
A significantly greater proportion of respondents (70\%) of RSWR agreed that the forests in their surroundings were dwindling, but $43 \%$ respondents of RBNP disagreed with the statement $\left(\chi_{1}^{2}=4.37, \mathrm{p}=0.037\right)$. This statement had a significant association with migration status $\left(\chi_{1}^{2}=4.95, p=0.026\right)$. A higher proportion $(66 \%)$ of immigrants agreed with the statement, while $52 \%$ of resident disagreed. There was a significant association of the perception of forest status with gender $\left(\chi_{1}^{2}=4.89, \mathrm{p}=0.027\right)$. A higher proportion $(77 \%)$ of female respondents agreed that forests had dwindled in comparison to male respondents $(59 \%)$. There was no significant difference between Tharus and non-Tharus $\left(\chi_{1}^{2}=2.10, p=0.148\right)$.

A significantly higher proportion of respondents (96\%) of RBNP than of RSWR $(89 \%)$ agreed with the statement that local people share responsibility of conserving natural resources $\left(\chi^{2}:=3.96, p=0.047\right)$. There was no significant association of this statement with gender $\left(\chi_{1}^{2}=0.91, p=0.340\right)$, ethnicity $\left(\chi_{1}^{2}=0.11, p=0.743\right)$, and landholdings $\left(\chi_{2}^{2}=0.52, p=0.772\right)$. Although people were harassed by wildlife, they were willing to share responsibilities for conservation $\left(\chi_{1}^{2}=0.52, p=0.473\right)$. When local people were satisfied with achievements of User Groups they were more likely to agree with sharing responsibilities for conservation $\left(\chi_{1}^{2}=5.16, p=0.023\right)$.

There was a significant difference in the perception of wildlife population trends among local people between the two protected areas $\left(\chi_{1}^{2}=58.58, \mathrm{p}=0.000\right)$. An overwhelming proportion $(91 \%)$ of respondents agreed that populations of wildlife in RBNP had increased while more than half $(66 \%)$ of respondents disagreed that wildlife populations 
in RSWR had increased. Respondents who had suffered from wildlife damage were more likely to agree that there was an increase in wildlife populations $\left(\chi_{1}^{2}=16.35, p=0.000\right)$. Respondents whose main vocation was agriculture were more likely to agree with the statement $\left(\chi_{1}^{2}=6.26, p=0.012\right)$. An overwhelming proportion $(90 \%)$ of Tharu agreed that wildlife populations increased, while only $59 \%$ of non-Tharus agreed with the statement.

There was a significant association between the perception on socioeconomic development and area $\left(\chi_{1}^{2}=14.53, p=0.000\right)$. More respondents $(70 \%)$ of RBNP agreed that there was improvement in living standard after the establishment of park than RSWR $(45 \%)$. There was no significant difference between Tharus and non-Tharus on attitude towards socioeconomic development $\left(\chi_{1}^{2}=1.57, \mathrm{p}=0.210\right)$. The likelihood of men and women agreeing with this statement was the same $\left(\chi_{1}^{2}=0.01, p=0.974\right)$. Respondents who were engaged in off farm activities did not associate these opportunities with conservation interventions $\left(\chi_{1}^{2}=0.56, p=0.453\right)$. Respondents who had not lost livestock and crops to wildlife were more likely to agree that there were improvements in the socioeconomic status of local people $\left(\chi_{1}^{2}=4.69, p=0.030\right)$.

There was a significant association of resource use conflicts with area $\left(\chi^{2}{ }_{1}=12.74, p=\right.$ 0.000 ). In RBNP, $81 \%$ of respondents agreed that they did not have problems with resource use after the establishment of the park and its buffer zones. In RSWR, only 59\% agreed that they did not have problem of resource use after the establishment of the reserve. Respondents belonging to the dependent and most dependent categories of 
resource use were more likely to agree with the statement that they did not have a problem of resource access $\left(\chi_{3}^{2}=13.58, \mathrm{p}=0.004\right)$. Perceptions about resource access were not related to gender $\left(\chi_{1}^{2}=0.15, p=0.703\right)$, ethnicity $\left(\chi_{1}^{2}=0.85, p=0.358\right)$, landholdings $\left(\chi_{2}^{2}=2.96, p=0.227\right)$, and occupation $\left(\chi_{1}^{2}=0.08, p=0.778\right)$.

The demographic and socioeconomic variables included in the regression model explained about $25 \%$ of the variation in conservation attitudes $(\mathrm{p}<0.01)$. Multiple regression results revealed that RBNP respondents were more likely to hold favorable attitudes than RSWR respondents $(p=0.049)$. Similarly, respondents who held more favorable attitudes were likely to be those who were satisfied with UGs activities ( $\mathrm{p}=$ $0.000)$, those who participated in the NGO sponsored trainings $(p=0.011)$, and those who were not harassed by wildlife $(\mathrm{p}=0.024)$. Other variables did not contribute to significant variation in conservation attitudes. The coding of each independent variable is indicated in parenthesis, with the sign of the coefficients showing whether associations are positive or negative (Table 17).

\subsection{Wildlife Harassment and Attitudes towards UGs}

There was a significant association between wildlife harassment and protected areas $\left(\chi^{2}\right.$, $=7.99, p=0.005)$. Significantly, a higher proportion $(77 \%)$ of households of RBNP suffered from wildlife damage than households of RSWR $(60 \%)$. Twenty three percent of households of RBNP and $40 \%$ of households of RSWR did not mention wildlife damage. There was a significant difference between the two protected areas about the expression of satisfaction towards UGs among local people $\left(\chi_{1}^{2}=4.44, p=0.035\right)$. In RBNP, $82 \%$ of 
respondents were satisfied with the achievements of their UGs while in RSWR 71\% were satisfied. Thus, a higher proportion (29\%) of respondents of RSWR were not satisfied with UGs achievements than RBNP respondents (18\%).

\subsection{Institutional Development and Strengthening}

With the passage of the Conservation Area Management Regulation (CAMR) in 1991 and the Buffer Zone Management Regulation (BZMR) in 1996, it became mandatory to solicit local people's participation in nature conservation and protected areas management. The CAMR and the BZMR vested power to declare conservation areas and to delineate buffer zones in the periphery of national parks and wildlife reserves, respectively. The BZMR stipulated that User Groups (UGs) should be formed at village/settlement level. These groups formed the foundation for a bottom-up approach to resource management within buffer zones and were envisioned as grassroots institutions responsible for conservation and sustainable development of their respective buffer zone units.

4.7.1 Institutional working procedures: Of 29 UGs, $79 \%$ were formed unanimously by villagers while $21 \%$ were formed by election among local leaders. There was no significant association between mode of user group formation and protected areas $(\mathrm{p}=$ 0.390). In RBNP, $71 \%$ of UGs were formed by consensus while $29 \%$ were formed by election. In RSWR, $87 \%$ of UGs were formed by consensus while $13 \%$ were formed by election (Table 18). Any adult person above 18 years is eligible for membership and women members are mandatory in UGs. 
All UGs of RBNP had female members on their executive committees while only three UGs of RSWR did. The number of female members varied from one to eight. Disadvantageous Groups (DAGs) were represented in six UGs of RBNP, but only in two UGs of RSWR. The members from DAGs on the executive committee varied from one to four. It was surprising that none of the UGs of RSWR had Tharus on the executive committee but all UGs of RBNP had Tharus members (one to nine) in the committee. In RBNP, one UG was meeting fortnightly, 12 monthly and one quarterly. In RSWR, three UGs were meeting weekly, seven fortnightly, three monthly, and two were not meeting at all.

The Maoist People's War had less impact on UGs activities in RBNP in comparison to RSWR ( $\mathrm{z}=-2.50, \mathrm{p}=0.0125)$. In RBNP, $86 \%$ of UGs were holding their regular meetings while only $47 \%$ of UGs in RSWR were holding their regular meetings at the time of survey. The reason given by respondents was that due to growing political tension; it was not feasible to call meetings. In many cases, the state's security forces instructed UGs not to hold meetings as a precaution to prevent Maoist infiltration and extortion. On some occasions, Maoist rebels threatened UG chairs not to call meetings because they thought that UGs were supporting the state. The longest abeyance of meetings (18 months) had occurred in RSWR, but the abeyance was for three months only in RBNP. At the time of the field visit, the average abeyance of meetings for RSWR was $10.62 \pm 7.46$ months $(\mathrm{N}=8)$ and for RBNP it was $2.5 \pm 0.71$ months $(\mathrm{N}=2)$. 
The BZMR requires each UG to prepare a five year work plan and submit it to the Buffer Zone Management Council for approval and allocation of budget. The Fisher's exact test showed that there was a significant association of work plan formulation with protected areas $(\mathrm{p}=0.017)$. All UGs of RBNP had five year work plans, but only $60 \%$ UGs of RSWR had. There also were more NGOs working in the buffer zones of RBNP than RSWR. The King Mahendra Trust for Nature Conservation (KMTNC), the Participatory Conservation Program (PCP), the Terai Arc Landscape (TAL), Center for Aid in Relief and Emergency (CARE) - Nepal and the Kisan Jagaran (Awareness among Farmers) were working with local people for conservation and sustainable development in the buffer zone of RBNP. During the time of fieldwork, only the PCP had significant presence and the KMTNC had just established its office in RSWR. KMTNC and PCP facilitated the drafting of five year work plans in RBNP and RSWR, respectively.

4.7.2 Resource management and demand fulfillment: In RBNP, of 14 UGs, 10 had their own buffer zone forests, but none of RSWR UGs had buffer zone forests. The size of buffer zone forests of RBNP varied from 10 ha to 150 ha. At the time of the study, no UG had facilitated the sale of non-timber forest products (NTFP) from their buffer zone forests. Seven UGs of RBNP were contemplating the promotion of NTFP marketing and were looking forward to devise strategic plans to this end.

When asked which institutional arrangement would be most efficient to manage resources in a sustainable manner, a high proportion (64\% in RBNP and $60 \%$ in RSWR) of UG chairs responded that local people were the most effective institute. About $21 \%$ 
and $33 \%$ of UG chairs of RBNP and RSWR, respectively, considered government agencies as the most effective institution. Some UG chairs (14\% in RBNP and $7 \%$ in RSWR) emphasized coordinated efforts of government agencies and local people for sustainable management of resources in the region (Table 19).

There was no significant difference in UGs' competence in fulfilling legitimate demands of members in the two areas $\left(\chi_{1}^{2}=0.29, \mathrm{p}=0.588\right)$. In RBNP, $50 \%$ of UGs were meeting their subsistence needs of natural resources from their buffer zone forests. Since there was no buffer zone forests in RSWR, funds collected through saving-credit program were the only common property. More than half $(60 \%)$ of UGs were not able to fulfill loan demands of their members while $40 \%$ fulfilled demands (Table 20 ).

4.7.3 Attitudes of conservation leaders: To implement landscape level conservation in the Western Terai, the TAL project - a joint undertaking of the Government of Nepal and WWF-Nepal Program, has been working in these areas since 2001. I asked UG chairs to express their opinions about the project. In the buffer zones, TAL was more pronounced in RBNP than in RSWR ( $p=0.001)$. All UG chairs of RBNP were familiar with TAL while only $60 \%$ of UG chairs of RSWR were familiar. I asked the respondents to rank the satisfaction level of overall TAL activities in the area. In RBNP, 21\% were highly satisfied, $50 \%$ moderately satisfied and $29 \%$ were not satisfied at all. An overwhelming proportion (93\%) of respondents were not satisfied with TAL in RSWR (Table 21). 
There was a significant difference in the respondent's understanding of the Regulations and Guidelines between the two areas $(\mathrm{p}=0.001)$. About $64 \%$ of respondents disagreed with the present Regulations and Guidelines in RBNP, but $80 \%$ of respondents in RSWR said that there was no problem with these. There were some $(20 \%)$ respondents who confessed that they had never studied the legal protocols so were unable to comment (Table 22).

4.7.4 Content analysis of the work plans: Operational plans were drafted by staff of NGOs in consultation with UGs. This was reflected in the contents and types of programs implemented. One of the progressive aspects of operational plans was the provision for compensation. UGs can levy nominal tax on resources, impose fine to defaulters, and accept donation from outside sources. Depositing 10-15\% income of the UGs into compensation fund is mandatory. The compensation fund is used to reimburse losses due to wildlife depredation, loss of life due to wildlife attack and property damage by natural calamities. Ecological risks such as pesticides and chemical fertilizers were mentioned, but no concrete programs were devised to tackle these problems. Forest management practices mentioned in operation plans were not intensive and based not on current science. The agricultural and livestock development sector got the least priority. The principal focus in this sector was goat raising. Human resource development and income generating programs were traditional and may not serve towards empowerment. Trainings mentioned in the plans such as sewing-cutting and knitting won't meet the objectives of income generation because most previous participants were not using the training for income-generating purposes. Another drawback of the plans was not 
mentioning the percentage of funds allocated for conservation versus development from the revenue earmarked to and income earned by UGs.

\section{DISCUSSION}

There were more male (186) than female (48) respondents. This is due to the social status and level of education. The literacy rate among females is lower in comparison to males $\left(\chi_{4}^{2}=25.20, p=0.000\right)$. Most female respondents $(60 \%)$ were illiterate while only $24 \%$ of the male respondents were. Socially, women have subordinate roles and less power in decision making so males are usually household heads. Since I targeted household heads for interview and women were reluctant to take part while men were present, there is an asymmetrical representation of gender in the survey. This may have implications on interpretation and generalization of results because women are more involved in forest resource extraction such as firewood, fodder and edibles (Mehta \& Kellert 1998).

The literacy rate $(68.8 \%)$ of the study area was significantly higher than the national average (53.7\%; CBS 2002). Significantly, more respondents of RSWR (76.1\%) are literate than those of RBNP $(62.4 \% ; p=0.001)$. This is consistent with the fact that RSWR is located near an urban center and is close to India, so local people have easy access to educational institutes. Additionally, Tharus constituted about half of the sample in RBNP and the illiteracy rate (36\%) among Tharus is higher than non-Tharus $(29 \%)$. This may have decreased the overall literacy rate of RBNP. The higher literacy rate in the buffer zones of RBNP and RSWR compared to their respective districts is attributed to 
extension programs of various NGOs. As part of awareness campaigns, many NGOs have undertaken adult literacy programs in these areas.

Tharus are the only ethnic tribe of the Terai. The downward spiral of Tharu began with the migration of other people from the mountains that started after the eradication of malaria in the early 1960 s. Ethnic heterogeneity caused by migration tends to dilute community solidarity (Ostrom 1990) and may cause inter-ethnic conflicts in resources use (Noss 1997). The plurality of communities should be aptly addressed in management strategies for sustainable management of natural resources. From conservation perspectives, the problems of immigration are: inflated population, higher discount rates, lowered commitments to conservation, and increased pressures on natural resources (Ostrom 1990; Gadgil et al. 1993; Kremen et al. 1994, Oates 1995). This may ultimately lead to the 'tragedy of the commons' (Hardin 1968). Although non-indigenous people are also capable of developing a knowledge base of local environment as they adapt (Browder 1995, Muchagata \& Brown 2000), they significantly alter the structure and composition of resources as they harvest (Nepstad et al. 1992).

The annual population growth rate of Nepal was 2.3\% for the period of 1991 to 2001 (CBS 2002). The annual population growth rate of Bardia (3.2\%) and Kanchanpur (4.6\%) Districts from which samples were drawn were much higher than the national average. The mean family size $(7.64 \pm 4.09)$ of the study area was also significantly higher than the national average $(5.44 ; \mathrm{t}=8.21, \mathrm{p}=0.000)$. One of the reasons for the higher growth rate is larger family sizes among Tharus. The average family size of Tharus $(8.91 \pm 5.42)$ 
was significantly higher than non-Tharus $(7.04 \pm 3.13 ; z=2.63, p=0.0087)$. Tharus used to live in extended families so responsibilities of bringing up children were shared, which may have served as an incentive to have more children, among other factors in traditional societies. The concept of the nuclear family is gaining popularity in the younger generation Tharus. The other reason attributed for rapid growth is migration of people from the Mountains to these areas. In the past, people migrated to these areas to reclaim fertile agricultural lands, to access physical facilities, and to take refuge from environmental hardships. At present, the Maoist insurgency has stoked the fuel of migration. Although the Maoist insurgency was not mentioned by respondents as a cause to migrate, there were camps established in community forests and public lands to provide shelter to people displaced from the Mountains by the armed conflict. The higher annual population growth around forest reserves due to civil strife is also documented elsewhere (Archalbad \& Noughton-Treves 2001) which is a main cause of failure of integrated conservation and development programs in such areas (Oates 1995).

The main challenge for resource managers in these areas is to curb forest encroachment. Freed bonded-laborers, political refugees and opportunists are clearing forests for settlements. The government of Nepal abolished the bonded-labor practice in 2001, but did not bring concrete programs for rehabilitation. Most bonded-laborers are Tharus and they have no alternative livelihood but subsistence agriculture. In a desperate attempt to procure agriculture lands, freed bonded-laborers are reclaiming government forests, community forests, and public lands. Similarly, people displaced by the armed conflict are resettled in forests and the government's acquiesce to deforestation caused by 
humanitarian needs did not receive much opposition from civil society. Taking advantage of the lax security situation, many opportunists are clearing forests. There are no studies addressing the encroachment issue so it is premature to conclude the extent and scope of current threats. Without a long lasting peace, reformative actions, and commitments to conservation by the government, these problems seem insurmountable. Most respondents already have tenure rights and this may serve as an incentive for sustainable resource management. One of the components of community natural resource management is to secure land tenure rights (Kellert et al. 2000), and this should be used as a benchmark to curb encroachment of forests which is the pressing challenge at present.

Although respondents have the same average size of land parcels between areas, a significantly high proportion $(73 \%)$ of RSWR respondents said that they get enough produce from their parcels. This is because there is an irrigation facility in RSWR, which is lacking in RBNP. The size of a land parcel may also influence the livestock size unit. In the past, Tharus had large parcels of land and used to keep large herds of livestock. They grazed livestock in forests. Large number of buffaloes in RBNP is due the fact that Tharus still use these animals as draught power while immigrants use oxen. Culturally they had never practiced stall feeding, but are now gradually adopting the practice because of imposition of conservation laws and influence of other groups. At present, there is no significant difference in the size of land parcels and numbers of livestock between Tharus and non-Tharus $(\mathrm{p}>0.10)$. Most Tharus are still peasant farmers and reduction in the size of land parcels and livestock may have negative impacts on their subsistence economy. 
Resource use patterns between ethnic Tharus and immigrant non-Tharus are different. Tharus never collected leaf litter from the forest to use as bedding material for livestock. However, non-Tharu immigrants used to collect leaf litter in their previous dwellings because the fertility of soil is very poor in the mountains, and they used to compost leaf litter to enrich agricultural fields. They are thus still practicing local knowledge acquired in mountains. Collection of leaf litter from forests may seriously deplete nutrients in the soil. Sal forests are more vulnerable to nutrient depletion by this practice because they are comparatively nutrient poor due to frequent fires that expel Nitrogen and dryness that slows down decay of biological materials. Resource use patterns are a function of economic status and cultural practices. Tharus earn significantly less annual cash income (US $\$ 397 \pm 388$ ) than non-Tharus (US $\$ 619 \pm 500 ; z=-3.15, p=0.0004$ ) from outside sources. Tharus most often collect green leaves to make leaf plates for their daily use while economically better off immigrants do not use leaf plates. Within the Tharu community, liquor is a must in rituals and social ceremonies so they collect the Dadari ${ }^{2}$ herb Elephantos scaber to ferment food materials and subsequently distill home brewed liquor. The amount of green leaves collected is insignificant in comparison to dry leaf litter, so the practice of Tharus is superior to immigrants from soil nutrient perspectives. These differences in resource use patterns have implications on the conservation and management of resources and should be taken into account while formulating management strategies.

\footnotetext{
${ }^{2}$ Root extract of this herb is mixed with rice and is used to make yeast for brewing liquor; medicinally applied for syphilis, rheumatic pain and foot and mouth disease of livestock
} 
The dependency of local people on natural resources depends on family size, socioeconomic status, ethnicity, availability and duration of residency. Tharus are more dependent on resources than non-Tharus. This result supports the finding of Sah and Heinen (2001). Economically Tharus are poorer than non-Tharus, and this is in contradiction to the theory that wealthier people would suffer most if restriction on forest resources is imposed (Hegde \& Enters 2000). Tharus are the indigenous people of the Terai, and they have good knowledge about the uses of local resources. Although immigrants quickly learn local knowledge (Browder 1995), their competence in resource use compared to indigenous people is largely unknown. Additionally, Tharus have larger family sizes so they collect more resources to meet subsistence needs. When resources are easily available, people collect more resources and fall into the category of most dependent. In RBNP, there are buffer zone forests from which local people are allowed to harvest resources, but in RSWR, there is no buffer zone forest. This is why more households of RBNP graze and collect fodder for livestock in buffer zone forests and public lands than households of RSWR. Firewood, thatch and timber are the three most important resources for local people. People of RBNP are collecting these resources in greater quantities than people of RSWR because they have places to harvest resources apart from the park. Due to the availability of resources and low annual cash income, respondents of RBNP are more dependent on resources.

Traditional trade systems of natural resources such as exchange for wage labor and barter for food materials, and to some extent conventional trade in local markets, were common among respondents. Significantly, a higher proportion of respondents of RBNP said that 
they were engaged in buying and selling of natural resources. Although RSWR is close to an urban center, the more trade in RBNP could be attributed to more availability and demand of resources. Irrigation facilities, access to market, technical support, and scarcity of resources all are impetuses to local people to adopt domestic cultivation of non-timber forest products in their agricultural fields. Since these conditions are met in RSWR, more respondents are interested in the program. No initiation had been taken to promote NTFPs from buffer zone forests during this study. Sustainable extraction of NTFPs is a silvicultural practice for forest management and conservation that bolsters the local economy by providing income generating activities (Mahapatra \& Mitchell 1997). Present rules and regulations are silent on the commercialization of NTFPs from buffer zone forests in Nepal. There is a need to forge clear guidelines to this end.

Popular participation in conservation can be achieved through various means. Becoming a member of grassroots institutions, participating in trainings, engaging in income generating activities, depositing money in saving-credit programs, and rewarding people for conservation initiatives are some forms of participation. There are many grassroots institutions in buffer zones such as User Groups, Women Groups, Forest Groups etc., and local people are exclusive members. Sewing-cutting, painting, vegetable farming, goat keeping, and pig raising trainings are given to local people for income generation, and leadership, conflict resolution and accountancy trainings are given to members of grassroots institutions. During the household surveys, I found that many recipients are not using new skills acquired through training for income generating purposes, but for subsistence use. These may be good for extension work but they are not meeting the 
objective. This is the reason why income-generating activities are not so prominent, and they failed to empower local people. Although there was no significant association between ethnicity and participation in training $\left(\chi_{1}^{2}=0.33, \mathrm{p}=0.506\right)$, more Tharus were participating in income generating activities $\left(\chi_{1}^{2}=5.49, \mathrm{p}=0.019\right)$. Biogas, improved stoves, piglet raising, drinking water, and scholarships are some of the benefits reported by respondents.

Significantly more Tharus got personal benefits than non-Tharus $\left(\chi_{1}^{2}=3.95, p=0.047\right)$ that is justifiable owing to their lower socioeconomic standing. Wider participation in RBNP is attributed to the declaration of the buffer zone and subsequent earmarking of revenue to local communities. Many NGOs are working in the buffer zone of RBNP implementing various integrated conservation and development programs. To reflect the bottom-up approach, NGOs solicit local people's participation while implementing programs. The ultimate goal of participation should be empowerment of local people so that they have more control over resources.

In the periphery of RBNP, public forests exist which are absent in the periphery of RSWR. Some of these forests were handed over to local people to manage under the buffer zone regime. With the change in management regime, these formally degraded forests are regenerating so well that local people have started harvesting resources. Local people in collaboration with park management can thus be successful in converting open access degraded forests into well protected neo-common property resources. This is the Government's effort to revive some aspects of common property regimes. Thus buffer 
zone management could be regarded as what Arnold (1998) calls 'emerging common property regime'. This is the reason why, in RBNP, $43 \%$ of respondents disagree with the statement that forests in their area have decreased, and an overwhelming proportion $(96 \%)$ agree with sharing responsibilities to protect natural resources. There has been a tremendous change in forest cover within past three decades, but local people's disagreement suggests that they take the recent time frame at the local scale to form their attitudes. Success stories of community forestry and buffer zone forests have spurred local people of RSWR to demand fringes of the reserve (up to 300 meter from the periphery) as buffer zone forests. Some UGs had submitted a concept paper to this end to the reserve authority. At the time of fieldwork, some UGs had issued grass cutting permits with verbal consent from the reserve authority. Considering overwhelming social pressures and the de facto open access status of the reserve periphery, it will be a strategic management decision to go along with UGs proposal. In the present rules and regulations, there is no provision for handing over part of a park or reserve as a buffer zone forest. Legal mechanism should be explored before initiating such programs.

People's assessment of wildlife populations was based on sightings during thatch collection inside protected areas, sightings in buffer zone forests, and frequency of crop damage. Over the past decade, populations of one-horned rhinoceros and Asian elephants have increased in RBNP and these animals are causing more problems for local people. About $91 \%$ of respondents said that there has been an increase in wildlife populations in RBNP. Local people have frequently seen wildlife inside the park and the buffer zone. According to local people, reasons for the increase are complete protection, decrease in 
poaching and addition of habitats (buffer zones). In RSWR, people do not go deep into the reserve to collect thatch grass, and the periphery of the reserve is not good habitat due to livestock grazing and illegal resource extraction by local people. These are the reasons why local people do not frequently see wildlife that are abundant inside the reserve. In RSWR, $56 \%$ of respondents said that wildlife populations have decreased. Crop depredation is thus less severe in RSWR and most people have not seen wildlife in their fields. RSWR abuts Laggabaggha Sanctuary of India so local people opine that decreases in wildlife populations are due to migration of wildlife to India and rampant poaching on the border. In fact, there been no records of wildlife decline in recent years in these two protected areas except for blue bull Boselaphous tragocamelus, white-rumped vulture Gyps bengalensis, slender-billed vulture G. tenurostris and Bengal Florican (Khatri 1993; Giri \& Gharty-Chhetri 2002; Baral et al. 2003). Populations of many other species (e.g. four species of deer, wild pigs, etc.) have increased.

People confound improvements in living condition with resource access, physical facilities and wildlife control. Local people are legally allowed to harvest natural resources from buffer zone forests as stipulated in the management plans. Previously, parks and reserves were the only source for thatch, but now it is found in many buffer zone forests as well. In the case of RBNP, local people are harvesting more thatch from these forests than from the park. Additionally buffer zone forests provided firewood, timber and fodder which are not allowed to be collected from the park. Some NGOs that have been working in the buffer zone of RBNP are the KMTNC, the PCP, the TAL, and the CARE-Nepal. These NGOs introduced many integrated conservation and 
development programs. Skill enhancement and income generating activities through training and welfare programs for marginalized communities to some extent led to better living standard.

These projects have also invested in community development programs such as road construction, drinking water supply, irrigation in agricultural lands, construction of schools, and establishment of health care centers. Local people praise the development components of these projects. The park authority, with its partner organizations, has addressed the problem of wildlife damage in local communities. The investment in trench and fence maintenance to deter wildlife entering crop fields, and compensation for the loss of life and damage to houses by endangered wildlife species, are taken as positive steps by the park authority. Economic development as a result of these projects is more pronounced in RBNP. Thus, significantly more respondents agreed that there has been an increase in the standard of living with the establishment of park.

The conflict arises when restrictions are placed on resource harvest. In the establishment phase, UGs put restrictions on resources harvested in buffer forests and people felt uncomfortable for a while. In such a situation, protected areas are vulnerable to trespassing because people illegally harvest resources to meet their needs (Straede \& Helles 2000). When local people were allowed to harvest resources from buffer zone forests, the conflict abated. To remediate resource scarcity, respondents in RBNP emphasized buffer zone forest management while in RSWR, they suggested permits to harvest from the reserve. The example of buffer zone forest is given by many respondents 
to substantiate their views on increased forest cover and shared responsibilities for conservation. Cursory observation in RBNP suggests that buffer zone forests have provided, to some extent, social and ecological buffers to the park, but more in-depth analysis is warranted.

People have stakes in participation and sharing of responsibilities for conservation. These are guided by the expectation of direct use of resources. They think that the resources that have been conserved will ultimately used by them. They used to ask why the park does not allow us to harvest old, dead and fallen trees. Most respondents think that wildlife does not have direct use values except for a few who see the tourism potential of the area. Non-consumptive uses of wildlife are obvious in many protected areas (Bandara \& Tisdell 2003), and this is the reason why it is taken as a revenue generating source for the government. People vehemently oppose the concept of park extension. According to local people, agricultural land is more desirable than protected areas. When survival is at stake, people discount ecological services provided by protected areas. Most productive protected areas in Nepal are in the Terai, where demand of agriculture lands is very high. The management authority should choose between quality and quantity. Instead of increasing size, the government should expand strategies of participatory and intensive management of existing protected areas and the matrix of forests around them.

Exclusion of outsiders and the free riding problem are challenges for efficient management of common pool resources. Respondents are skeptical about their competency in sole management of resources. Local people are helpless when their 
buffer zone forests were encroached by squatters, freed bonded-laborers, and political refugees. They doubt they would be able to keep common pool resources as closed access in absence of strong support from the government for law enforcement. Experience elsewhere shows that local people cannot fight with international poachers and cannot exclude outsiders free riding their resources (Spinage 1998). Local people are efficient police - a rotational guard system can check irregularities at the local level. The problem of poachers and wildlife traders should be addressed at national and international levels, which is a function of the state. The concerted effort of local people and the state based on participatory principles is important for emerging common property regime. Respondents citing the example of community forests also hint for collaborative management.

Multiple regression results indicated that RBNP respondents have more favorable attitudes than RSWR respondents do $(\mathrm{p}=0.049)$. This is substantiated by the fact that the mean attitude score of RBNP $(8.4 \pm 1.44)$ was significantly higher than the score of $\operatorname{RSWR}(7.7 \pm 1.66 ; \mathrm{t}=3.24, \mathrm{p}=0.0007)$. The buffer zone of RBNP $(328 \mathrm{sq} \mathrm{km})$ was declared in 1996, and since then local people have gotten $30-50 \%$ of the revenue generated by the park. This has observable impacts on socioeconomic development of the area and empowerment of local people for resource management. During the time of this fieldwork, the proposed buffer zone of RSWR was not officially declared. The presence of NGOs and their programs to provide socioeconomic benefits are pronounced in the buffer zone of RBNP while one NGO was working in the proposed buffer zone of RSWR and its programs are diffuse. Due to the provision of buffer zone forests, more resources 
are available to RBNP respondents. These are some reasons that help to explain differences in conservation attitudes between two areas.

The objective of buffer zone management is to relieve human pressures on protected areas by providing socioeconomic benefits to local people. To meet the objective, some of the strategies employed are empowerment of local people, management of problem wildlife, and harnessing local institutions. In most integrated conservation and development programs, training is an integral component of core programs. In the study area, training sponsored by NGOs was a significant predictor of conservation attitudes ( $\mathrm{p}$ $=0.011)$. The main objectives of training programs are to enhance skill development of local people and to elevate environmental awareness. Therefore, NGOs take an opportunity to educate participants about conservation during training sessions. Research elsewhere show that people who participated in training programs held more favorable attitudes towards conservation (Mehta \& Kellert 1998; Mehta \& Heinen 2001). Wildlife damage is strongly associated with negative attitudes towards conservation (Heinen 1993; Newmark et al. 1993; De Boer \& Baquete 1998; Mehta \& Kellert 1998). As expected, respondents who suffered from wildlife held more negative attitudes towards conservation $(\mathrm{p}=0.024)$. Mostly people living in the periphery of protected areas are subsistence farmers and research elsewhere shows that people who farm tend to have more negative attitudes than those engaged in off-farm activities (Akama et al. 1995). Community level benefits do not off set individual costs (Gibson \& Marks 1995), and people have negative attitudes when their livelihoods are under threats from wildlife (Gillingham \& Lee 1999). This is corroborated with the fact that people who expressed 
satisfaction towards UGs were more likely to hold favorable attitudes towards conservation $(p=0.000)$. The formation of UGs provided the platform for wider participation. When public forests are handed over to UGs as buffer zone forests, local people have control over resources. Loss of local control over resources results in negative attitudes (Mehta \& Heinen 2001). By participating in community forestry program, local people have favorable attitudes (Mehta \& Kellert 1998). This is because people have control over resources and appreciate the importance of ownership.

Field research conducted in developing countries shows that among demographic variables, age, education, gender, and ethnicity are significant predictor of conservation attitudes (Fiallo \& Jabcobson 1995; Mehta \& Kellert 1998; Gillingham \& Lee 1999; Sah \& Heinen 2001). None of these variables was a significant predictor of attitudes in this study ( $p>0.05$ ). According to Sah and Heinen (2001), Tharus held more negative attitudes towards conservation than others in Ghodaghodi Tal, Nepal. This is contrary to the finding that there is no significant difference in conservation attitudes among ethnic groups here $(p>0.05)$.

The surprising finding of multiple regression is that people benefiting personally tend to have more negative attitudes, however, this is not statistically significant $(p=0.381)$. This may be because most personal benefits such as sewing machines, improved stoves, piglets etc. are distributed after the completion of training. People might have attributed benefits to training and not to conservation. Other reasons could be inequitable 
distribution of benefits (Ferraro \& Kramer 1997) and perceptions that benefits are "donor provided' rather than 'conservation earned' (Lewis \& Phiri 1998).

With the amendment in National Park and Wildlife Conservation Act of 1973, the Buffer Zone Management Regulation (BZMR) was passed in 1996. The Regulation mentions User Committee (UC) only. As per the Regulation, the UC should have at least nine members in the executive committee and five years tenure. The UCs are free to hold meetings as required and decisions are made by simple majority. The Regulation is progressive because it mentions hunting concessions of common species in buffer zones and describes methods of reimbursing compensation for wildlife damage. After a lapse of three years, the Buffer Zone Management Guideline (BZMG) came into effect. The Guideline imposed restrictions on the number (21 at most) of the UCs within a buffer zone. To achieve the goal, a new grassroots institution, the User Group (UG), was introduced which was not in the Regulation. All previously functioning UCs were relegated to UGs. The regressive action alienated local people and many UG chairs do not agree with the present Guideline. This is the reason why many UG chairs ( 9 of 14) of RBNP suggested amendments in the Regulation and the Guideline.

As per the Guideline, UCs are formed at the Village Development Committee (VDC [political constituency]) level with representatives from UGs within the VDC. People can exercise voting rights to elect UGs, but not to elect UCs. Previously, UGs directly communicated with the buffer zone council, but with the addition of one vertical tier, 
UCs became mediators between them. There is a clear shift from participation to representation, and UGs lost a great deal of authority in the vertical power distribution.

There are some serious flaws in the Guideline. First, it puts restrictions on the number of members (at most nine) on the executive committee. The Regulation is flexible on the size of the executive committee. The Rule 8 (2) mentions at least nine members on the executive committee. Second, the term of the UGs and the UCs is debatable. Section 12(18) of the Guideline describes the term of the UGs as 2.5 years. However, the term of officials of the UCs is five years. All officials of the UCs are represented from the UGs. Therefore, the term of the officials expire before the completion of the UCs tenure. In such cases, the validity of the UC is questionable on legal grounds. Forming UGs every two and half year incurs many administrative burdens and may undermine a stability of grassroots institutions. In theory, the Guideline should be clear and progressive, but in practice, it is ambiguous and regressive. Reconciling contradictions between the Regulation and the Guideline is imperative.

The Guideline demands meetings of the UGs. The Section 12 (9) dictates that UGs should meet once every two weeks. The Regulation is lenient on the UC meetings because UCs could hold meetings as and when required. However, the Section 10 (5) of the Guideline stipulates frequency of the UC meetings at least four times a year not exceeding three months gaps between each meeting. Proposals sent by the UGs are discussed at UC meetings and decisions are made. UGs do not have long agendas to 
discuss so it is not effective to make fortnightly meetings mandatory because, in practice, most UGs are violating the rule.

The rubric of the programs to be implemented and allocation of the budget are explicitly mentioned in the Guideline. At least, $30 \%$ of the total budget should be allocated for conservation programs. However, in the work plans, there is no consistency of budget allocation as per the Guideline. Community development programs received high priority while allocating the budget.

\section{CONCLUSIONS}

The participation of women in conservation and development programs is limited in Nepal. This is due to gender-based differences in socioeconomic status and education level. The literacy rate among women was only $40 \%$ compared to $76 \%$ of men. Similarly, more ethnic Tharus were illiterate $(36 \%)$ than non-Tharus $(29 \%)$. The low illiteracy rate among women and ethnic groups may hinder their participation in conservation. There is a need to increase their literacy rate so that it helps in their empowerment and fosters in participation. Still $77 \%$ of respondents primarily depend on subsistence agriculture and $86 \%$ of respondents had land tenure. The Government's inefficient land reform policies letting squatters and refugees settle in forests, and fail to set land tenure as benchmark to prevent encroachment - and lack of off-farm income has increased pressures on natural resources. More than $95 \%$ of respondents raised one or more types of livestock, the mean livestock size unit was $4.18 \pm 3.75$, and none raised improved breeds of livestock. 
Traditional livestock raising practices are not compatible with conservation objectives. The Government should give priority to coordination among stakeholders, and make policy reforms in agriculture and livestock sectors for successful implementation of landscape conservation.

Eight types of natural resources were extracted from the park and buffer zone forests of RBNP while seven types were extracted from the reserve in RSWR. Respondents in RBNP were more dependent on natural resources than in RSWR. There is spatiotemporal variability in resource dependency and use patterns. There has been slight decrease in resource dependency from historic times, but still most people are heavily dependent on natural resources for subsistence. Poor and ethnic Tharus were more dependent on natural resources which suggests that forest resources are safety net for them. Although Tharus are more dependent on natural resources, their traditional practices are superior to non-Tharus from conservation perspectives. Resource use patterns among ethnic groups should be taken into account for sustainable management of resources. Resource dependency is a function of socioeconomic status, ethnicity, and availability. Income generation activities may help to alleviate pressures on natural resources.

After the promulgation of community-based conservation legislation, the park authority and non-governmental organizations instituted a platform for local people to participate in conservation and sustainable development programs. Local people became members of grassroots institutions, participated in trainings, formed saving-credit groups, and 
engaged in income generating activities. More NGOs were in the buffer zone of RBNP than in RSWR and this could be the reason why more respondents of RBNP had participated in such activities than of RSWR. At present forms, these activities failed to empower local people but garnered favorable attitudes towards conservation.

The mean conservation attitude score of RBNP respondents $(8.4 \pm 1.4)$ was significantly higher than those of RSWR $(7.7 \pm 1.6 ; p=0.0012)$. The difference in conservation attitudes is due to the conservation intervention programs. The significance presence of NGOs, empowerment of grassroots institutions, and socioeconomic development contribute to favorable conservation attitudes. These are reasons why local people of RBNP have more favorable attitudes towards conservation than RSWR. A multiple regression model showed that participation in trainings, wildlife damage and satisfaction towards User Groups (UGs) are significant predictors of conservation attitudes.

All UGs of RBNP had female members on their executive committees while only three UGs of RSWR did. In RBNP, $86 \%$ of UGs were holding their regular meetings while only $47 \%$ of UGs in RSWR did at the time of survey. All UGs of RBNP had five year work plans, but only $60 \%$ UGs of RSWR had. About $71 \%$ of UGs in RBNP had their own buffer zone forests, but none of RSWR UGs had. When grassroots institutions are legally recognized and management authority is delegated, they are more strengthened. They are more resilient in times of political instability because of wider support. Taking into account the institutional capacity, demand for land and pressures on natural resources, the government should expand strategies of participatory and intensive 
management of existing protected areas and matrix of forests around them. The evolution of landscape approach is timely and may help secure sustainability of the entire landscape. 


\section{TABLES}

Table 1. Frequency distribution of ethnicity in two protected areas

\begin{tabular}{lrrrr}
\hline Ethnicity/castes & \multicolumn{1}{c}{ RBNP } & \multicolumn{1}{l}{ RSWR } & \multicolumn{1}{c}{ Total } & \multicolumn{1}{c}{ Statistics } \\
\hline Tharu & $64(51.2 \%)$ & $11(10.1 \%)$ & $75(32.1 \%)$ & $\chi^{2}=48.85$ \\
Brahman & $23(18.4 \%)$ & $29(26.6 \%)$ & $52(22.2 \%)$ & $\mathrm{p}=0.000$ \\
Chhetri & $26(20.8 \%)$ & $49(44.9 \%)$ & $75(32.1 \%)$ & $\mathrm{df}=4$ \\
Occupational castes & $8(6.4 \%)$ & $18(16.5 \%)$ & $26(11.1 \%)$ & \\
Hill tribes & $4(3.2 \%)$ & $2(1.8 \%)$ & $6(2.6 \%)$ & \\
\cline { 1 - 4 } Total & 125 & 109 & 234 & \\
\hline
\end{tabular}

Table 2. Frequency distribution of education level of respondents of two areas

\begin{tabular}{lllll}
\hline Education Level & RBNP & RSWR & Total & Statistics \\
\hline Illiterate & $47(37.6 \%)$ & $26(23.85 \%)$ & $73(31.2 \%)$ & $\chi^{2}=18.1410$ \\
Literate & $28(22.4 \%)$ & $19(17.4 \%)$ & $47(20.1 \%)$ & $\mathrm{p}=0.001$ \\
Primary & $24(19.2 \%)$ & $16(14.7 \%)$ & $40(17.1 \%)$ & $\mathrm{df}=4$ \\
Secondary & $23(18.4 \%)$ & $33(30.3 \%)$ & $56(23.9 \%)$ & \\
College & $3(2.4 \%)$ & $15(13.8 \%)$ & $18(7.7 \%)$ & \\
\cline { 1 - 4 } Total & 125 & 109 & 234 & \\
\hline
\end{tabular}

Table 3. Comparison of family size between area and ethnic groups

\begin{tabular}{llllll}
\hline Area_ethnicity & N & Mean & Min & Max & Mean Rank \\
\hline RBNP and Tharu & 64 & 9.23 & 2 & 32 & 137.92 \\
RBNP and non-Tharu & 61 & 5.95 & 3 & 10 & 88.39 \\
RSWR and Tharu & 11 & 7.00 & 4 & 10 & 118.36 \\
RSWR and non-Tharu & 98 & 7.71 & 1 & 23 & 122.77 \\
\cline { 1 - 4 } Total & 234 & 7.64 & 1 & 32 & \\
\hline
\end{tabular}

Table 4. Percentage of immigrants in two protected areas

\begin{tabular}{lllll}
\hline Protected Areas & Migrated & Not-migrated & Total & Statistics \\
\hline RBNP & $87(69.6 \%)$ & $38(30.4 \%)$ & 125 & $\chi^{2}=28.25$ \\
RSWR & $105(96.3 \%)$ & $4(3.7 \%)$ & 109 & $\mathrm{p}=0.000$ \\
Total & $192(82.1 \%)$ & $42(17.9 \%)$ & 234 & $\mathrm{df}=1$ \\
\hline
\end{tabular}


Table 5. Average landholdings in hectare among different ethnic groups in two areas

\begin{tabular}{llllll}
\hline Area_Ethnicity & N & Mean & Min & Max & Mean Rank \\
\hline RBNP and Tharu & 64 & 0.68 & 0.07 & 2.71 & 111.57 \\
RBNP and non-Tharu & 61 & 0.69 & 0.03 & 3.15 & 116.93 \\
RSWR and Tharu & 11 & 0.96 & 0.20 & 2.03 & 155.14 \\
RSWR and non-Tharu & 96 & 0.67 & 0.03 & 4.74 & 117.50 \\
\cline { 1 - 4 } Total & 232 & 0.69 & 0.03 & 4.74 & \\
\hline
\end{tabular}

Table 6. Percent of respondents meeting need of staple food from their farm

\begin{tabular}{lllll}
\hline Protected Areas & Sufficient & Insufficient & Total & Statistics \\
\hline RBNP & $49(39.2 \%)$ & $76(60.8 \%)$ & 125 & $\chi^{2}=27.5224$ \\
RSWR & $80(73.4 \%)$ & $29(26.6 \%)$ & 109 & $\mathrm{p}=0.000$ \\
Total & $129(55.1 \%)$ & $105(44.9 \%)$ & 234 & $\mathrm{df}=1$ \\
\hline
\end{tabular}

Table 7. Average and range of livestock size unit in two protected areas

\begin{tabular}{lrrrrrrrr}
\hline Livestock Size & \multicolumn{3}{c}{ RBNP $(\mathrm{N}=119)$} & \multicolumn{4}{c}{ RSWR $(\mathrm{N}=106)$} \\
\cline { 2 - 9 } Units (LSU) & $\mathrm{N}$ & Mean & Min & Max & N & Mean & Min & Max \\
\hline Cattle & 82 & 3.52 & 0.80 & 38.40 & 100 & 2.72 & 0.40 & 10.40 \\
Buffalo & 68 & 2.34 & 0.50 & 7.00 & 75 & 1.81 & 0.50 & 5.50 \\
Sheep/Goat & 72 & 0.68 & 0.20 & 2.80 & 28 & 0.42 & 0.20 & 1.00 \\
Pig & 52 & 0.45 & 0.30 & 1.80 & 3 & 0.30 & 0.30 & 0.30 \\
\hline
\end{tabular}

Table 8 . Frequency of resources harvested by respondents of two protected areas

\begin{tabular}{|c|c|c|c|c|c|}
\hline \multirow{2}{*}{$\begin{array}{l}\text { Extractive resource } \\
\text { categories }\end{array}$} & \multicolumn{2}{|c|}{$\operatorname{RBNP}(\mathrm{N}=125)$} & \multicolumn{2}{|c|}{ RSWR $(N=109)$} & \multirow{2}{*}{$\begin{array}{c}\chi^{2} \\
\text { (p value) }\end{array}$} \\
\hline & Yes & No & Yes & No & \\
\hline Firewood & $68.0 \%$ & $32.0 \%$ & $57.8 \%$ & $42.2 \%$ & 0.106 \\
\hline Thatch & $92.8 \%$ & $7.2 \%$ & $77.9 \%$ & $22.0 \%$ & 0.001 \\
\hline Grasses & $52.0 \%$ & $48.0 \%$ & $44.0 \%$ & $55.9 \%$ & 0.224 \\
\hline Leaf litter & $61.6 \%$ & $38.4 \%$ & $33.9 \%$ & $66.1 \%$ & 0.000 \\
\hline Edibles & $42.4 \%$ & $57.6 \%$ & $10.1 \%$ & $89.9 \%$ & 0.000 \\
\hline Tree fodder & $20.0 \%$ & $80.0 \%$ & $1.8 \%$ & $98.2 \%$ & 0.000 \\
\hline Herbs & $15.2 \%$ & $84.8 \%$ & $0.9 \%$ & $99.1 \%$ & 0.000 \\
\hline Timber & $40.8 \%$ & $59.2 \%$ & - & - & - \\
\hline
\end{tabular}


Table 9. Nonparametric correlation of resource use score with continuous variables

\begin{tabular}{lcccl}
\hline Variables & Spearman's Rho & $\mathrm{p}$ value & $\mathrm{N}$ & Significant \\
\hline Family Size & 0.11 & 0.093 & 234 & Yes at $\mathrm{p}<0.10$ \\
Landholdings & -0.08 & 0.213 & 232 & No \\
Cash Income & -0.27 & 0.001 & 201 & Yes \\
Livestock Size Unit & 0.11 & 0.086 & 225 & Yes at $\mathrm{p}<0.10$ \\
Recency time & 0.32 & 0.000 & 234 & Yes \\
\hline
\end{tabular}

Table 10. Frequency distribution of resource dependency in two areas

\begin{tabular}{lrrrr}
\hline Dependent scale & RBNP & RSWR & Total & Statistics \\
\hline Not dependent & $7(5.6 \%)$ & $26(23.8 \%)$ & $33(14.1 \%)$ & $\chi^{2}=35.62$ \\
Somewhat dependent & $26(20.8 \%)$ & $43(39.4 \%)$ & $69(29.5 \%)$ & $\mathrm{p}=0.000$ \\
Dependent & $63(50.4 \%)$ & $31(28.4 \%)$ & $94(40.2 \%)$ & $\mathrm{df}=3$ \\
Most dependent & $29(23.2 \%)$ & $9(8.3 \%)$ & $38(16.2 \%)$ & \\
\cline { 1 - 4 } Total & 125 & 109 & 234 & \\
\hline
\end{tabular}

Table 11. Number and percentage of households mentioning the grazing sites

\begin{tabular}{lrrr}
\hline Where people graze livestock? & RBNP & RSWR & Statistics \\
\hline Forests & $10(8.4 \%)$ & $12(11.3 \%)$ & $\chi^{2}=23.42$ \\
Community pastures & $33(27.7 \%)$ & $4(3.8 \%)$ & $\mathrm{p}=0.000$ \\
Private and stall feed & $76(63.9 \%)$ & $90(84.9 \%)$ & $\mathrm{df}=2$ \\
\hline Total & 119 & 106 & \\
\hline
\end{tabular}

Table 12. Number and percentage of households mentioning the source of fodder

\begin{tabular}{lrrr}
\hline Where from people get fodder? & RBNP & RSWR & Statistics \\
\hline Private land & $87(73.1 \%)$ & $91(85.8 \%)$ & $\chi^{2}=5.51$ \\
Public and community forests & $32(26.9 \%)$ & $15(14.2 \%)$ & $\mathrm{p}=0.019$ \\
\hline Total & 119 & 106 & $\mathrm{df}=1$ \\
\hline
\end{tabular}

Table 13. Number and percentage of households mentioning the source of energy

\begin{tabular}{lrrr}
\hline What people use for cooking? & RBNP & RSWR & Statistics \\
\hline Energy inefficient mud stoves & $112(89.6 \%)$ & $98(89.9 \%)$ & $\chi^{2}=0.02$ \\
Improved mud stoves & $5(4.0 \%)$ & $4(3.7 \%)$ & $\mathrm{p}=0.991$ \\
Alternative energy sources & $8(6.4 \%)$ & $7(6.4 \%)$ & $\mathrm{df}=2$ \\
\hline Total & 125 & 109 & \\
\hline
\end{tabular}


Table 14. Number and percentage of respondents suggesting measures to solve the problem of firewood scarcity

\begin{tabular}{lrrr}
\hline Suggestions for firewood problem & RBNP & RSWR & Statistics \\
\hline Permit to collect from parks & $17(20.0 \%)$ & $46(54.7 \%)$ & $\chi^{2}=35.98$ \\
Buffer zone forests & $25(29.4 \%)$ & $4(4.7 \%)$ & $\mathrm{p}=0.000$ \\
Private plantation & $6(7.1 \%)$ & $13(15.5 \%)$ & $\mathrm{df}=4$ \\
Improved stoves & $8(9.4 \%)$ & $3(3.6 \%)$ & \\
Alternative energy & $29(34.1 \%)$ & $18(21.4 \%)$ & \\
\cline { 1 - 3 } Total & 85 & 84 & \\
\hline
\end{tabular}

Table 15. Frequency distribution of households participating in conservation interventions in two areas

\begin{tabular}{lrrrrr}
\hline Conservation & \multicolumn{2}{c}{ RBNP $(\mathrm{N}=125)$} & \multicolumn{2}{c}{ RSWR $(\mathrm{N}=109)$} & $\begin{array}{c}\chi^{2} \\
\text { interventions }\end{array}$ \\
\cline { 2 - 5 } & Yes & No & Yes & No & palue \\
\hline Membership & $36(28.8 \%)$ & $89(71.2 \%)$ & $14(12.8 \%)$ & $95(87.2 \%)$ & 0.003 \\
Trainings & $44(35.2 \%)$ & $81(64.8 \%)$ & $21(19.3 \%)$ & $88(80.7 \%)$ & 0.007 \\
Benefits & $45(36.0 \%)$ & $80(64.0 \%)$ & $11(10.1 \%)$ & $98(89.9 \%)$ & 0.000 \\
Saving-Credit & $67(53.6 \%)$ & $58(46.4 \%)$ & $72(66.1 \%)$ & $37(33.9 \%)$ & 0.053 \\
Income & $22(17.6 \%)$ & $103(82.4 \%)$ & $5(4.6 \%)$ & $104(95.4 \%)$ & 0.002 \\
generation & & & & & \\
\hline
\end{tabular}


Table 16. Percent of respondents agreeing or disagreeing with conservation statements

\begin{tabular}{|c|c|c|c|c|c|c|}
\hline \multirow{2}{*}{$\begin{array}{l}\text { S. } \\
\text { No. }\end{array}$} & \multirow[t]{2}{*}{ Statements } & \multicolumn{2}{|c|}{$\operatorname{RBNP}(\mathrm{N}=125)$} & \multicolumn{2}{|c|}{ RSWR $(\mathrm{N}=109)$} & \multirow{2}{*}{$\begin{array}{c}\chi^{2} \\
p \text { value }\end{array}$} \\
\hline & & Disagree & Agree & Disagree & Agree & \\
\hline 1 & $\begin{array}{l}\text { Forests around your village } \\
\text { have decreased in recent } \\
\text { years. }\end{array}$ & 43.55 & 56.45 & 30.28 & 69.72 & 0.037 \\
\hline 2 & $\begin{array}{l}\text { It is responsibility of local } \\
\text { people to protect natural } \\
\text { resources. }\end{array}$ & 04.13 & 95.87 & 11.01 & 88.99 & 0.047 \\
\hline 3 & $\begin{array}{l}\text { If there is unlimited access to } \\
\text { forests for fuel wood and } \\
\text { fodder, forests will be } \\
\text { disappeared soon. }\end{array}$ & 00.83 & 99.17 & 00.92 & 99.08 & 0.941 \\
\hline 4 & $\begin{array}{l}\text { There are more wild animals } \\
\text { now than ten years ago. }\end{array}$ & 09.09 & 90.91 & 55.96 & 44.04 & 0.000 \\
\hline 5 & $\begin{array}{l}\text { What people and their } \\
\text { livestock need are more } \\
\text { important than saving plants } \\
\text { and wild animals. }\end{array}$ & 67.77 & 32.23 & 66.06 & 33.94 & 0.783 \\
\hline 6 & $\begin{array}{l}\text { My living condition } \\
\text { improved since the protected } \\
\text { area's creation. }\end{array}$ & 30.40 & 69.60 & 55.05 & 44.95 & 0.000 \\
\hline 7 & $\begin{array}{l}\text { After the establishment of } \\
\text { buffer zone forests/reserve } \\
\text { you don't have problem of } \\
\text { access to resources. }\end{array}$ & 19.35 & 80.65 & 40.74 & 59.26 & 0.000 \\
\hline 8 & $\begin{array}{l}\text { It is important to set aside a } \\
\text { place for the animals and } \\
\text { plants to live in. }\end{array}$ & 19.17 & 80.83 & 22.22 & 77.78 & 0.569 \\
\hline 9 & $\begin{array}{l}\text { It is important to protect the } \\
\text { animals and plants so that } \\
\text { our children may know and } \\
\text { use them. }\end{array}$ & 21.60 & 78.40 & 17.59 & 82.41 & 0.443 \\
\hline 10 & $\begin{array}{l}\text { There is an equitable } \\
\text { distribution of common pool } \\
\text { resources and benefits. }\end{array}$ & 17.74 & 82.26 & 19.44 & 80.56 & 0.739 \\
\hline 11 & $\begin{array}{l}\text { You are willing to contribute } \\
\text { for conservation cause. }\end{array}$ & 08.26 & 91.74 & 02.78 & 97.22 & 0.073 \\
\hline
\end{tabular}


Table 17. Multiple regression of conservation attitude score on demographic and socioeconomic variables

\begin{tabular}{lrrrr}
\hline Independent Variables & Coefficient & Std. Error & \multicolumn{1}{c}{$\mathrm{t}$} & $\mathrm{p}$ \\
\hline Protected Areas (RSWR =1) & -0.556 & 0.280 & -1.99 & $0.049^{*}$ \\
Gender (Male = 1) & 0.097 & 0.289 & 0.34 & 0.736 \\
Age (in years) & 0.007 & 0.009 & 0.75 & 0.452 \\
Education (formal schooling =1) & 0.037 & 0.097 & 0.38 & 0.704 \\
Occupation (non-agriculture =1) & 0.149 & 0.119 & 1.25 & 0.212 \\
Ethnicity (non-Tharus = 1) & 0.138 & 0.114 & 1.21 & 0.227 \\
Family Size & 0.009 & 0.034 & 0.27 & 0.784 \\
Landholdings (in ha) & 0.043 & 0.195 & 0.22 & 0.827 \\
Livestock Size Unit & 0.005 & 0.037 & 0.12 & 0.901 \\
Resource Dependency Score & 0.012 & 0.016 & 0.69 & 0.489 \\
Annual Income (log transformed) & 0.110 & 0.117 & 0.94 & 0.349 \\
Memberships (Yes = 1) & 0.207 & 0.257 & 0.80 & 0.423 \\
Trainings (Yes = 1) & 0.620 & 0.241 & 2.57 & $0.011^{*}$ \\
Personal Benefits (Yes = 1) & -0.231 & 0.263 & -0.88 & 0.381 \\
Income Generating Activities (Yes = 1) & 0.435 & 0.301 & 1.45 & 0.149 \\
Wildlife Damage (Yes = 1) & -0.531 & 0.234 & -2.27 & $0.024^{*}$ \\
Satisfaction Towards UGs (Yes =1) & 0.941 & 0.247 & 3.81 & $0.000^{*}$ \\
\hline
\end{tabular}

$\mathrm{F}_{17,169}=3.25, \mathrm{p}=0.0000, \mathrm{R}$-squared $=0.2464,{ }^{*}$ significant at $\mathrm{p}<0.05$

Table 18. Frequency distribution of mode of Users' Group formation

\begin{tabular}{lcccc}
\hline Mode of Formation & \multicolumn{2}{c}{ RBNP } & \multicolumn{2}{c}{ RSWR } \\
\hline Consensus & 10 & $(71 \%)$ & 13 & $(87 \%)$ \\
Election & 4 & $(29 \%)$ & 2 & $(13 \%)$ \\
\hline Total & 14 & $(100 \%)$ & 15 & $(100 \%)$ \\
\hline
\end{tabular}

Table 19. Perception of UG chairs on effective institute for resource management

\begin{tabular}{lllll}
\hline Effective Institutions & \multicolumn{2}{l}{ RBNP } & \multicolumn{2}{l}{ RSWR } \\
\hline Government & 3 & $(22 \%)$ & 5 & $(33 \%)$ \\
Local People & 9 & $(64 \%)$ & 9 & $(60 \%)$ \\
Both & 2 & $(14 \%)$ & 1 & $(7 \%)$ \\
\hline Total & 14 & $(100 \%)$ & 15 & $(100 \%)$ \\
\hline
\end{tabular}


Table 20. Frequency distribution of responses whether UGs are fulfilling demands

\begin{tabular}{lllll}
\hline Demands fulfillment & \multicolumn{2}{l}{ RBNP } & \multicolumn{2}{l}{ RSWR } \\
\hline No & 7 & $(50 \%)$ & 9 & $(60 \%)$ \\
Yes & 7 & $(50 \%)$ & 6 & $(40 \%)$ \\
\hline Total & 14 & $(100 \%)$ & 15 & $(100 \%)$ \\
\hline
\end{tabular}

Table 21. UG chairs' attitudes towards TAL in two areas

\begin{tabular}{lll}
\hline Satisfaction with TAL & RBNP & RSWR \\
\hline Not at all & $4(29 \%)$ & $14(93 \%)$ \\
Moderately & $7(50 \%)$ & $1 \quad(7 \%)$ \\
Highly & $3(21 \%)$ & - \\
\hline Total & $14(100 \%)$ & $15(100 \%)$ \\
\hline
\end{tabular}

Table 22. UG chairs attitudes towards the BZMR and Guideline

\begin{tabular}{lll}
\hline Regulations & RBNP & RSWR \\
\hline Agree & $5(36 \%)$ & $12(80 \%)$ \\
Disagree & $9(64 \%)$ & $3(20 \%)^{*}$ \\
\hline Total & $14(100 \%)$ & $15(100 \%)$ \\
\hline
\end{tabular}

* Respondents had never studied the rules and regulations so were unable to comment

Table 23. Losses of agencies under the Ministry of Forest and Soil Conservation

\begin{tabular}{llrrrrr}
\hline Departments & $\begin{array}{l}\text { District Based } \\
\text { Offices }\end{array}$ & Area & $\begin{array}{l}\text { Range } \\
\text { Post }\end{array}$ & $\begin{array}{l}\text { Training } \\
\text { Centers }\end{array}$ & $\begin{array}{l}\text { Armed Security } \\
\text { Camps }\end{array}$ & Total \\
\hline DoF & 22 & 39 & 217 & 2 & 2 & 282 \\
DNPWC & 2 & 4 & 13 & - & - & 19 \\
DSWC & 4 & - & 1 & - & - & 5 \\
\hline Total & 28 & 43 & 231 & 2 & 2 & 306 \\
\hline
\end{tabular}

Source: Karki and Bhattarai 2004 


\section{FIGURES}

Figure 1. Map of Nepal depicting spatial distribution of protected areas

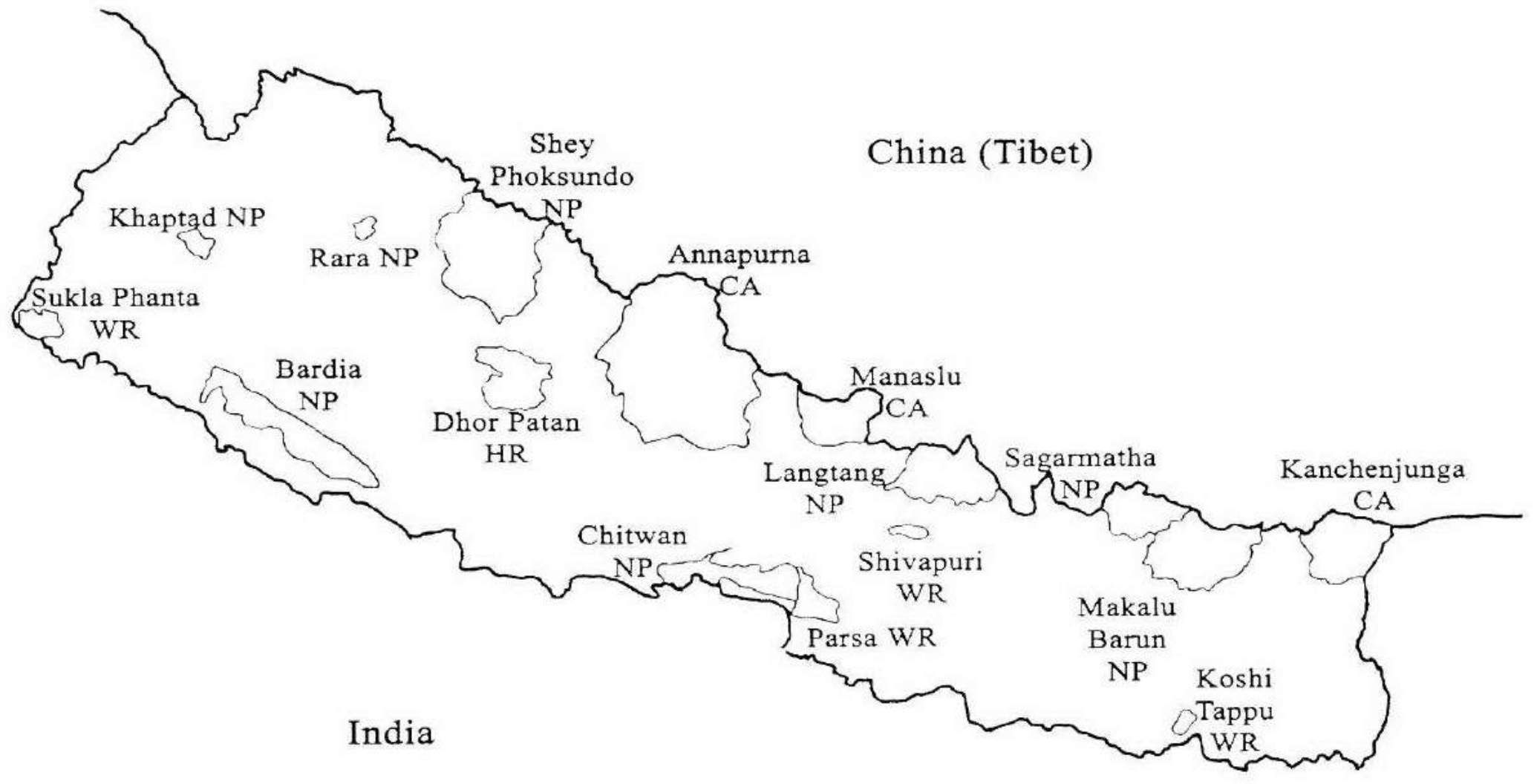

Photo Courtesy: Heinen 2001 
Figure 2. RBNP and RSWR with sampled households in the buffer zones

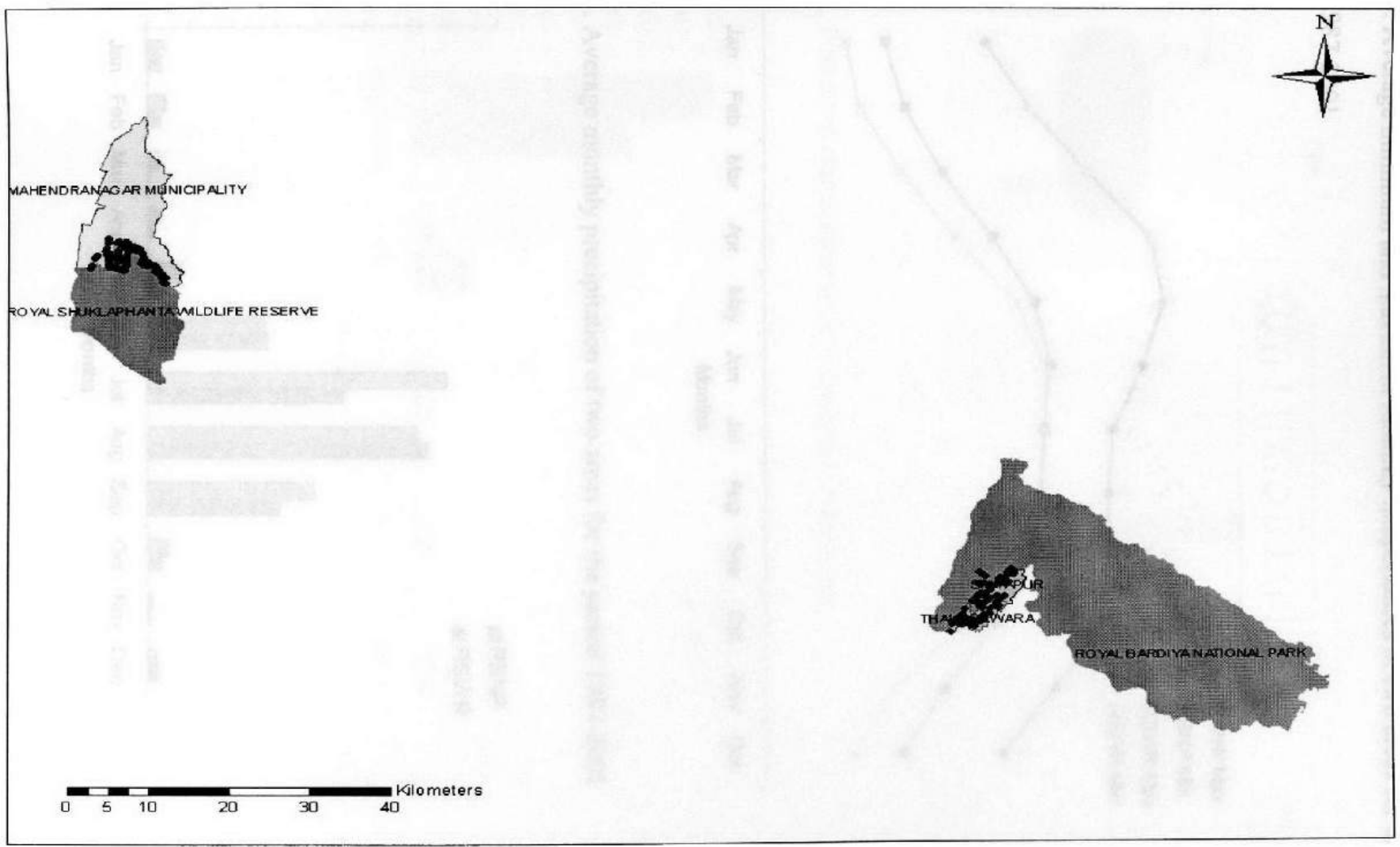


Figure 3. Average minimum and maximum monthly temperatures of two areas for the period 1987-2001

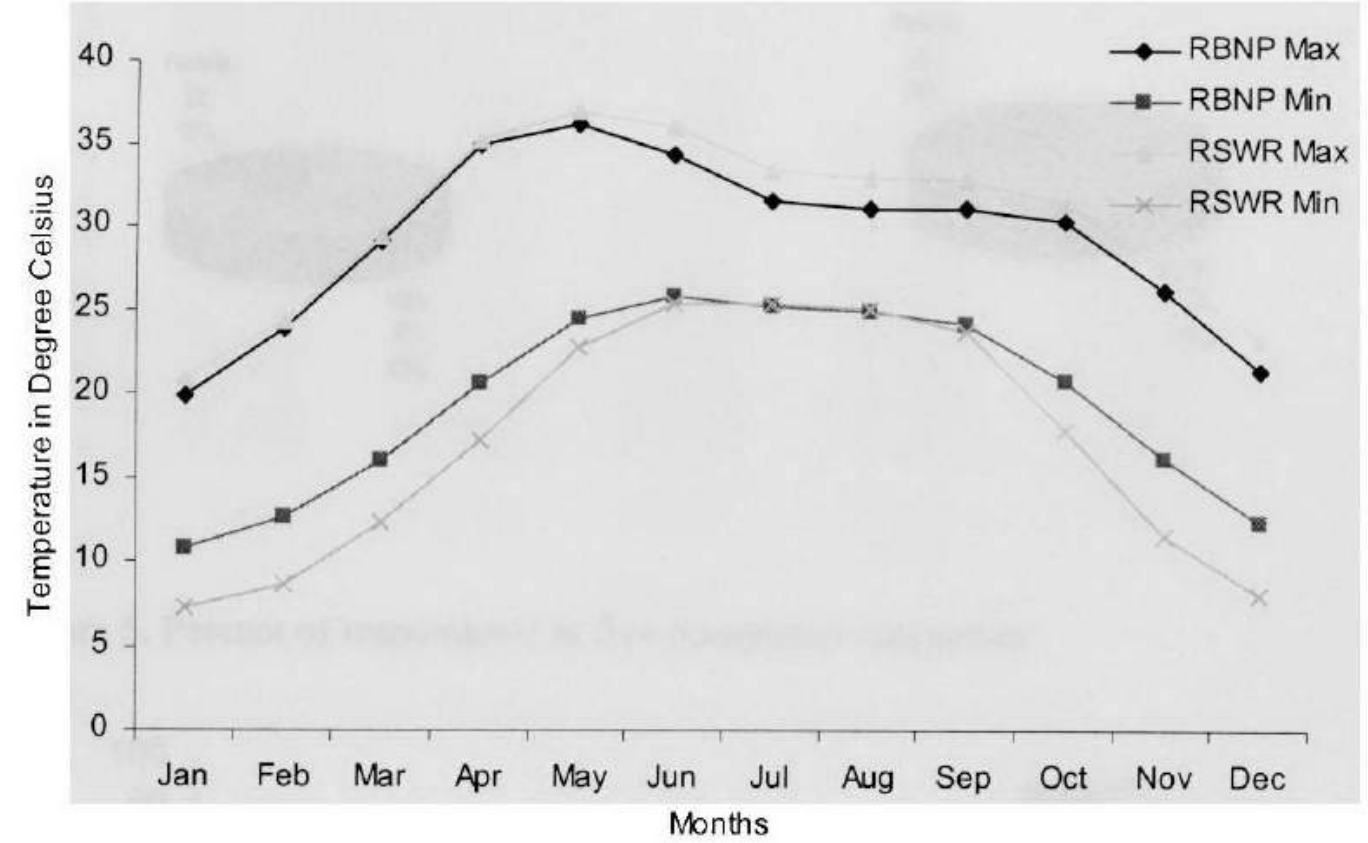

Figure 4. Average monthly precipitation of two areas for the period 1987-2001

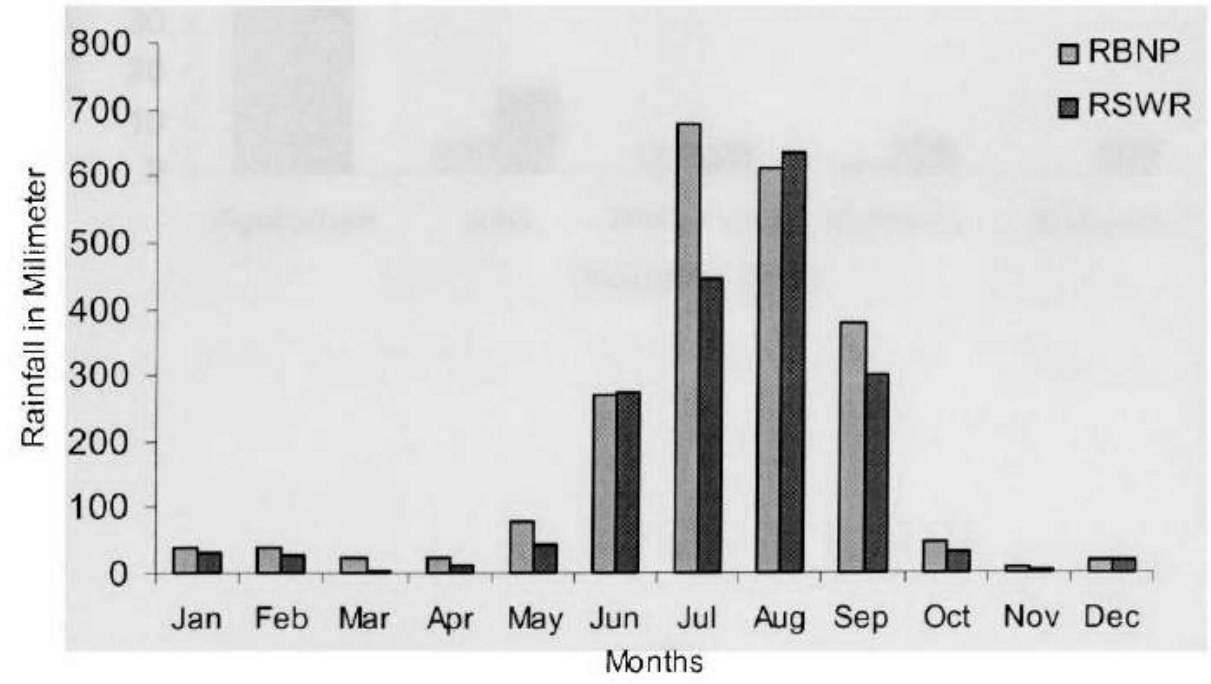


Figure 5. Percentage of male and female respondents in two protected areas

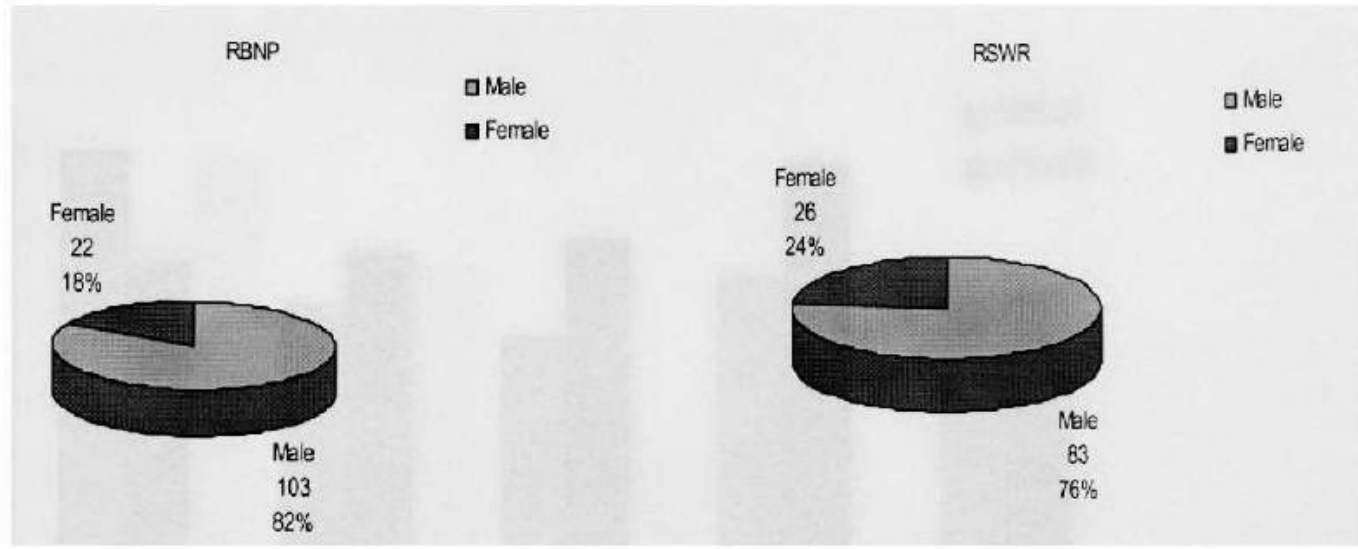

Figure 6. Percent of respondents in five occupation categories

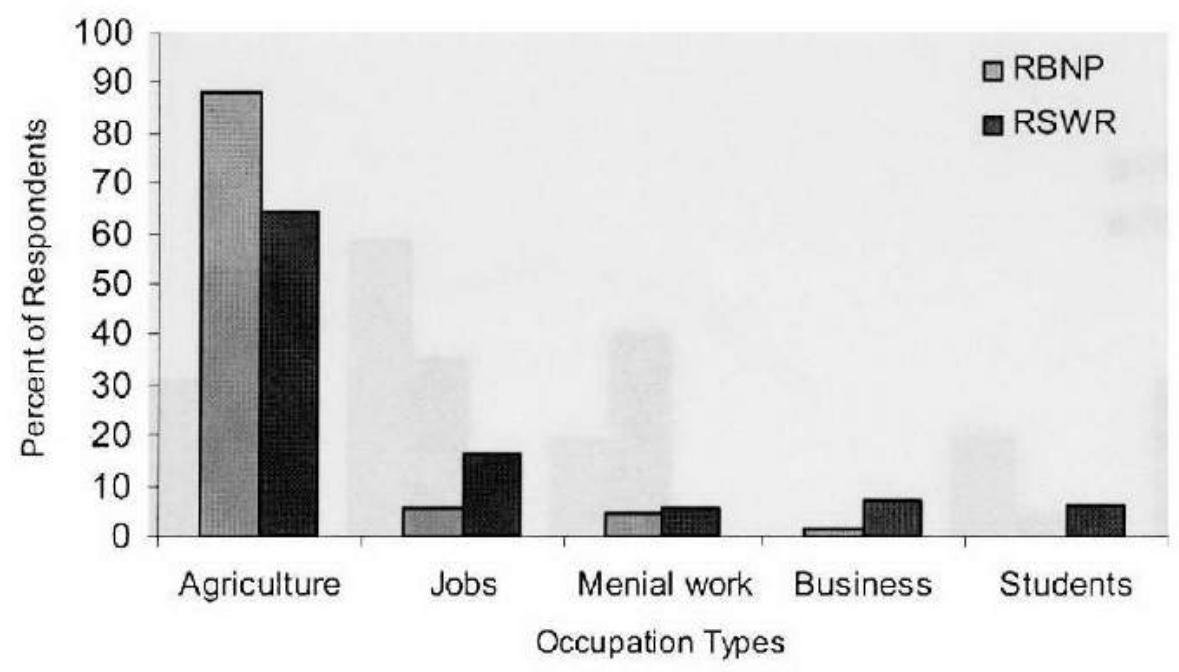


Figure 7. Average family size among ethnic groups in two areas

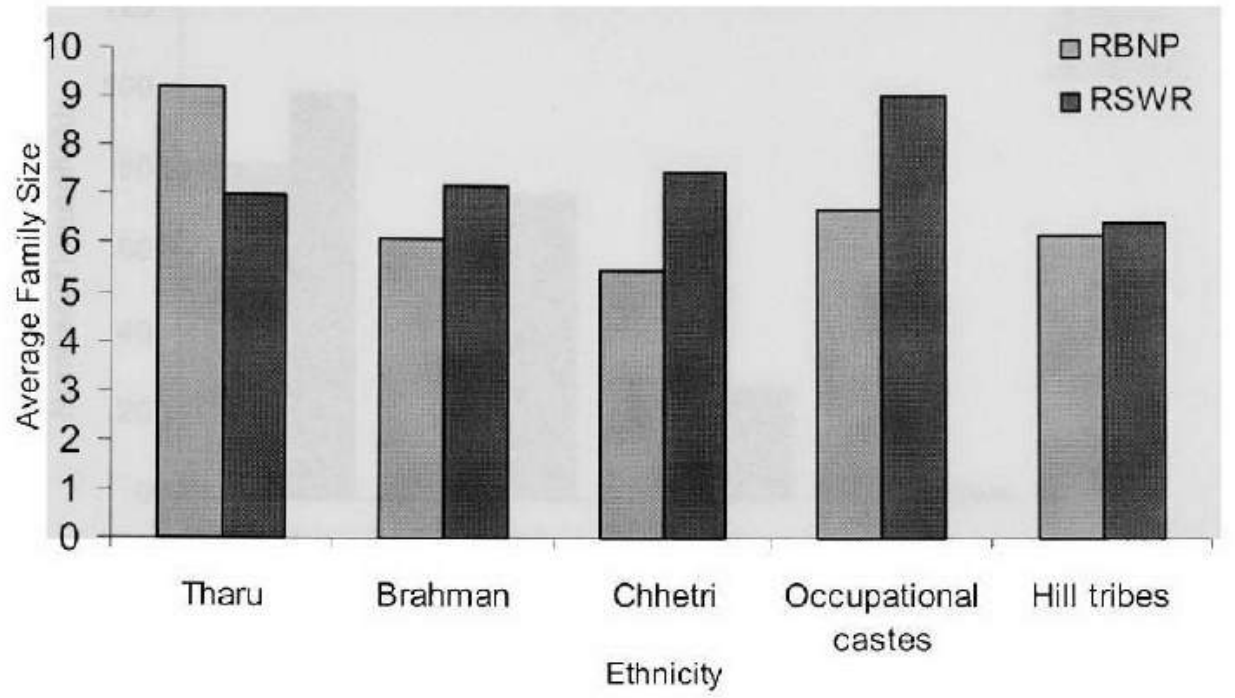

Figure 8. Average landholdings among ethnic groups in two areas

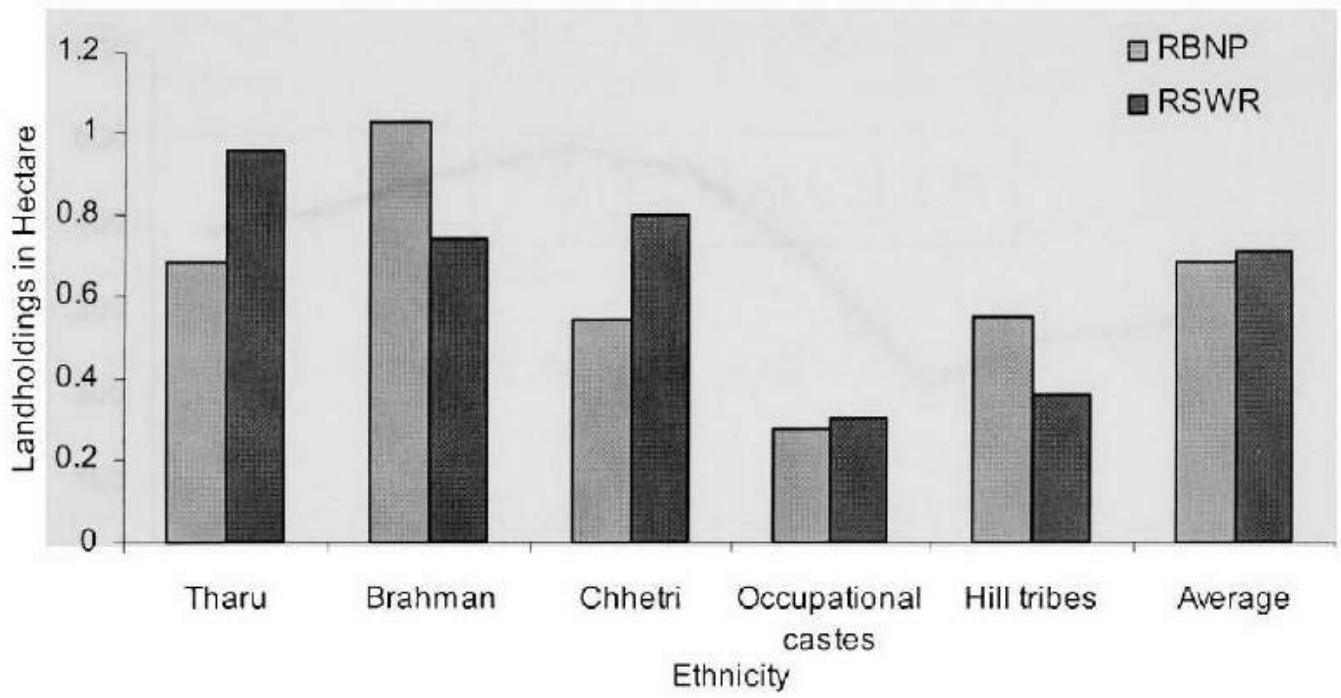


Figure 9. Frequency of households rearing four types of livestock in two areas

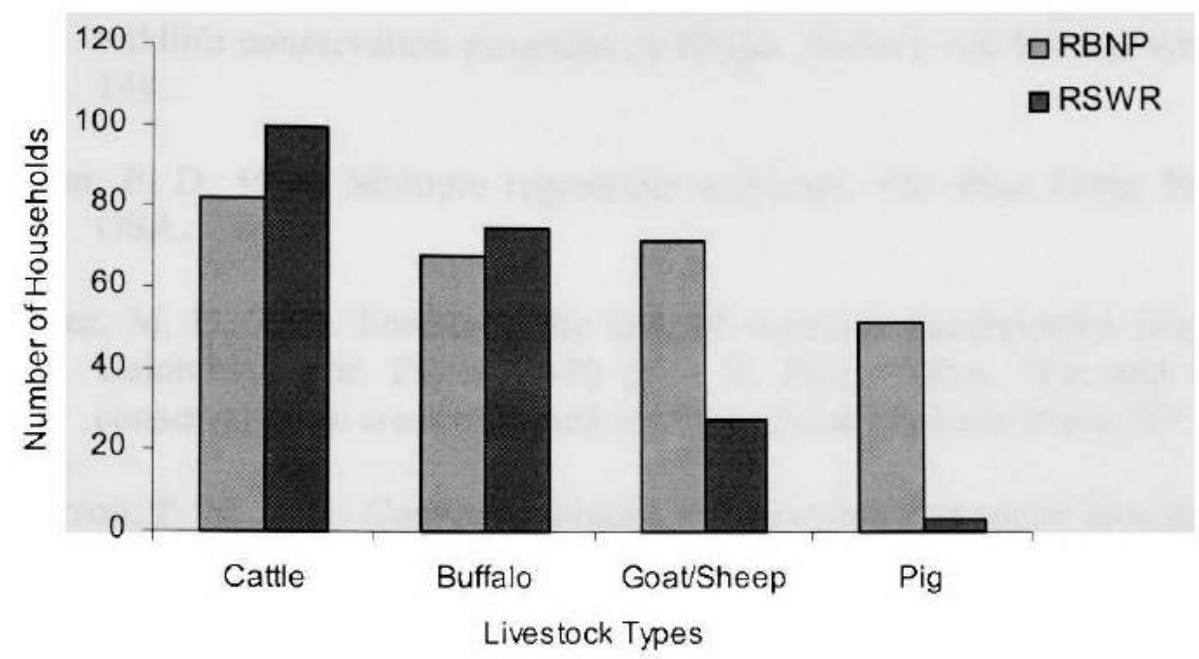

Figure 10. Total number of tourist arrivals per year since the beginning of the Maoists insurgency

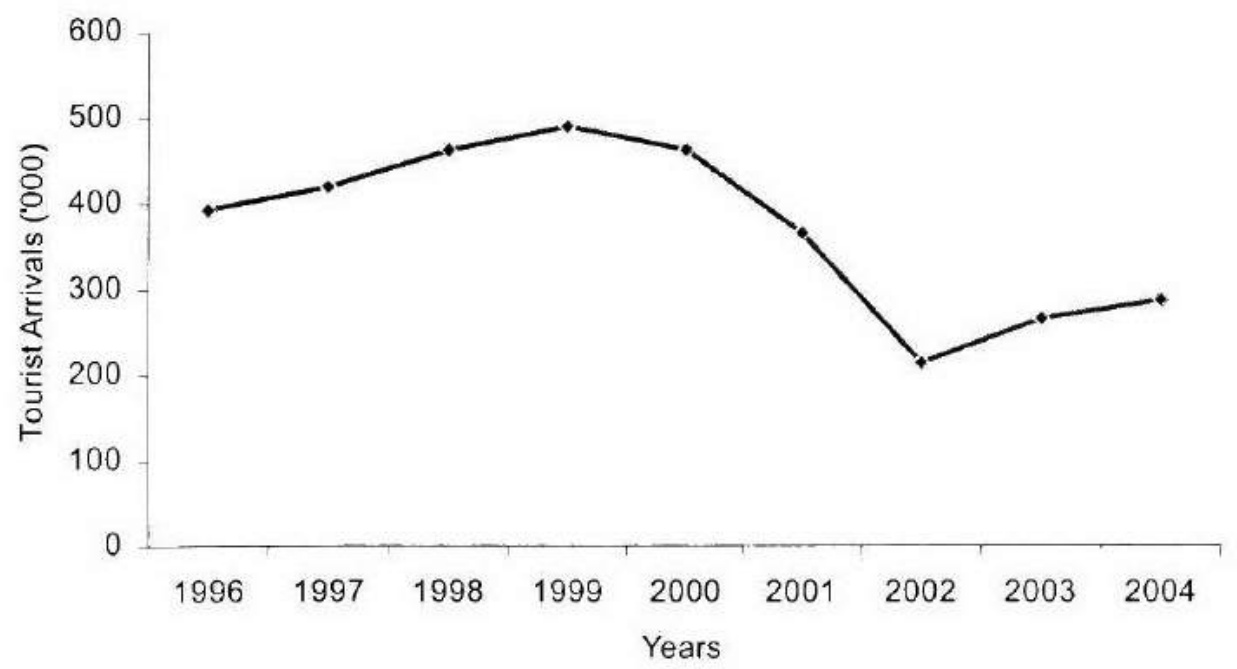

Source: Nepal Tourism Board 2005 


\section{REFERENCES}

Akama, J. S., C. L. Lant, and G. W. Burnett. 1995. Conflicting attitudes toward state wildlife conservation programs in Kenya. Society and Natural Resources 8: 133144.

Allison, P. D. 1998. Multiple regression: a primer. The Pine Forge Press, California, USA.

Alvarez, M. D. 2003. Forests in the time of violence: conservation implications of the Colombian war. Pages 49-70 in S. V. Price, editor. War and tropical forests: conservation in areas of armed conflicts. Food Products Press, NY.

Anderson, P. N. 2001. Community-based conservation and social change amongst south Indian honey-hunters: an anthropological perspective. Oryx 35 (1): 81-83.

Archabald, K., and L. Naughton-Treves. 2001. Tourism revenue-sharing around national parks in Western Uganda: early efforts to identify and reward local communities. Environmental Conservation 28 (2): 135-149.

Arnold, J.E.M. 1998. Managing forests as common property. FAO Forestry Paper 136, FAO, Rome.

Bandara, R., and C. Tisdell. 2003. Comparison of rural and urban attitudes to the conservation of Asian elephants in Sri Lanka: empirical evidence. Biological Conservation 110:327-342.

Baral, N., N. Timilsina, and B. Tamang. 2003. Status of Bengal Florican Houbaropsis bengalensis in Nepal. Forktail 19: 51-55.

Bista, D. B. 1987. People of Nepal. $5^{\text {th }}$ edition. Ratna Pustak Bhandar, Kathmandu, Nepal.

Browder, J. 1995. Redepmtive communities: indigenous knowledge, colonist farming systems, and conservation of tropical forests. Agriculture and Human Values 12 (1): 17-30.

Brandon, K., K.H. Redford and S.E. Sanderson, editors. 1998. Parks in peril: people, politics and protected areas. The Nature Conservancy Press and Island Press, Washington, D.C., USA.

Brown, K. 1997. Plain tales from the grasslands: extraction, value and utilization of biomass in Royal Bardia National Park, Nepal. Biodiversity and Conservation 6: $59-74$. 
Budhathoki, P. 2003. Nepal's conservation in crisis: empowering people to secure natural resources. Journal of Forest and Livelihood 2 (2): 72-75.

CBS. 2001. Statistical year book of Nepal 2001. Central Bureau of Statistics, Kathmandu, Nepal.

Chapagain, K. 2002. Thirty-four rhinoceros killed in eight months. The Kathmandu Post, December 20.

Chaudhary, R. P. 1998. Biodiversity in Nepal: status and conservation. Craftsman Press, Bangkok, Thailand.

Collier, P. 2000. Economic causes of civil conflict and their implications for policy. World Bank, Washington, D.C.

Cox, T. 1990. Land rights and ethnic conflict in Nepal. Economic and Political Weekly June 16-23:1318-1320.

Davalos, L. M. 2001. The San Lucas mountain range of Colombia: how much conservation is owed to the violence? Biodiversity and Conservation 10:69-78.

De Boer, W. F., and D. S. Baquete. 1998. Natural resource use, crop damage and attitude of rural people in the vicinity of the Maputo Elephant Reserve, Mozambique. Environmental Conservation 25: 208-218.

Dinerstein, D., and E. D. Wikramanayake. 1993. Beyond 'hotspots': how to prioritize investments in biodiversity in the Indo-Pacific region. Conservation Biology 7:5365.

Dinerstein, E. 1979. An ecological survey of Royal Karnali Wildlife Reserve, Nepal. Part II: Habitat animal interactions. Biological Conservation 16:265-300.

DNPWC. 2001. Annual report (2000-2001). Department of National Parks and Wildlife Conservation, Kathmandu.

DNPWC. 2003. Royal Bardia National Park Management Plan 2001-2005. His Majesty Government of Nepal, Department of National Parks and Wildlife Conservation.

DNPWC. 2005. Revenue generation in protected areas. The Department of National Parks \& Wildlife Conservation, Kathmandu, Nepal. Available from http://www.dnpwc.gov.np/ (accessed on February 9, 2005).

Dudley, J. P., J. R. Ginsberg, A. J. Plumptre, J. A. Hart, and L. C. Campos. 2002. Effects of war and civil strife on wildlife and wildlife habitats. Conservation Biology 16(2): 319-329. 
Eltringham, S. K., and R. C. Malpas. 1993. The conservation status of Uganda's game and forest reserves in 1982 and 1983. African Journal of Ecology 31: 91-105.

Ferraro, P. J., and R. K. Kramer. 1997. Compensation and economic incentives: reducing pressure on protected areas. Pages 187-211 in R. A. Kramer, C. Van Schaik, and J. Johnson, editors. Last stand: protected areas and the defense of tropical biodiversity. Oxford University Press, New York, USA.

Fiallo, E. A., and S. K. Jacobson. 1995. Local communities and protected areas: attitudes of rural residents towards conservation and Machalilla National Park, Ecuador. Environmental Conservation 22(3): 241-249.

Formoli, T. A. 1995. The impacts of the Afghan-Soviet war on Afghanistan's environment. Environmental Conservation 22: 66-69.

Gadgil, M., F. Berkes, and C. Folke. 1993. Indigenous knowledge for biodiversity conservation. Ambio 22:151-156.

Gautam, G. 2004. Poachers rule the roost in hunting reserve. The Himalayan Times, July 09.

Gibson, C. K., and S. A. Marks. 1995. Transforming rural hunters into conservationists: an assessment of community-based wildlife management program in Africa. World Development 23 (6): 941-957.

Gillingham, S., and P. C. Lee. 1999. The impact of wildlife-related benefits on the conservation attitudes of local people around the Selous Game Reserve, Tanzania. Environmental Conservation 26(3): 218-228.

Gilmour, D. 2003. Retrospective and prospective view of community forestry in Nepal. Journal of Forest and Livelihood 2: 5-7.

Giri, J. B., and S. Gharty-Chhetri. 2002. Study of vultures in western lowland Nepal. Oriental Bird Club Bulletin 36: 11-13.

Goldstone, J. A. 1996. Saving the environment (and political stability too): institutional responses for developing nations. Environmental Change and Security Report 2: $33-34$.

Hamilton, A., A. Cunningham, D. Byarugaba, and F. Kayanja. 2000. Conservation in a region of political instability: Bwindi Impenetrable Foreset, Uganda. Conservation Biology 14(6): 1722-1725.

Hardin, G. 1968. The tragedy of the commons. Science 162: 1243-1248. 
Hart, T., and J. Hart. 1997. Conservation and civil strife: two perspectives from central Africa. Conservation Biology 11(2): 308-314.

Hartup, B. K. 1994. Community conservation in Belize: demography, resource use, and attitudes of participating landowners. Biological Conservation 69: 235-241.

Hegde, R., and T. Enters. 2000. Forest products and household economy: a case study from Mudumalai Wildlife Sanctuary, Southern India. Environmental Conservation 27 (3): 250-259.

Heinen, J. T. 1993. Park-people relations in Koshi Tappu Wildlife Reserve, Nepal: a socio-economic analysis. Environmental Conservation 20(1): 25-34.

Heinen, J. T. 1996. Human behavior, incentives, and protected area management. Conservation Biology 10: 681-684.

Heinen, J. T., and B. Kattel. 1992. Parks, people, and conservation: a review of management issues in Nepal's protected areas. Population and Environment 14 (1): $49-84$.

Heinen, J. T., and D. P. Chapagain. 2002. On the expansion of species protection in Nepal: advances and pitfalls of new efforts to implement and comply with CITES. Journal of International Wildlife Law and Policy 5: 235-250.

Heinen, J. T., and J. N. Mehta. 1999. Conceptual and legal issues in the designation and management of conservation areas in Nepal. Environmental Conservation 26(1): 21-29.

Heinen, J. T., and J. N. Mehta. 2000. Emerging issues in lagal and procedural aspects of buffer zone management with case studies from Nepal. Journal of Environment \& Development 9(1): 45-67.

Heinen, J. T., and S. Rayamajhi. 2001. On the use of goal-oriented project planning for protected area management in Nepal. Environmental Practice 3: 227-236.

Heinen, J. T., and S. Shrestha. 2005. Evolving policies for conservation: an historical profile of the protected area system of Nepal. Environmental and Urban Planning

Heinen, J. T., and P. B. Yonzon. 1994. A review of conservation issues and programs in Nepal: from a single species focus toward biodiversity protection. Mountain Research and Development 14 (1): 61-76.

HMG. 1971. Soil survey of Bardia division. Forest resource survey publication. His Majesty Government of Nepal. 
HMG. 1973. National Parks and Wildlife Conservation Act 2029. Nepal Gazette 29: 114.

HMG. 1996. Conservation Area Management Regulations of 2053. Nepal Gazette 3, (Suppliment).

Hutt, M., editor. 2004. Himalayan people's war: Nepal's Maoist rebellion. Indiana University Press, Indianapolis, USA.

Infield, M. 1988. Attitudes of rural communities towards conservation and a local conservation area in Natal, South Africa. Biological Conservation 45: 21-46.

Infield, M., and A. Namara. 2001. Community attitudes and behaviour towards conservation: an assessment of a community conservation programme around Lake

Ite, U.E. 1996. Community perceptions of the Cross River National Park, Nigeria. Environmental Conservation 23 (4): 351-357.

IUCN. 1991. Caring for the Earth: a strategy for sustainable living. IUCN/UNEP/WWF, Gland, Switzerland.

Jain, B. C. 1991. Tharu tribe and the institution of marriage. Man and Life 17:163-168.

Jnawali, S. R., and P. Wegge. 1993. Space and habitat use by a small re-introduced population of greater one horned rhinoceros (Rhinoceros unicornis) in Royal Bardia National Park in Nepal- A preliminary report. Pages 208-217 in O. A. Ryder, editor. Proceedings of international conference on rhinoceros biology and conservation, Zoological Society, San Diego, USA.

Kaimowitz, D., and A. Faune. 2003. Contras and commandants: armed movements and forest conservation in Nicaragua's Bosawas Bioshpere Reserve. Pages 21-47 in S. V. Price, editor. War and tropical forests: conservation in areas of armed conflicts. Food Products Press, NY.

Kane, H. 1995. The hour of departure: forces that create refugees and migrants. Paper 125. WorldWatch, Washington, D.C.

Kanyamibwa, S. 1998. Impact of war on conservation: Rwandan environment and wildlife in agony. Biodiversity and Conservation 7: 1399-1406.

Karki, A., and B. Bhattarai, editors. 2004. Whose war? Economic and socio-cultural impacts of Nepal's Maoist-Government conflict. NGO Federation of Nepal. 
Khatri-Chhetri, S. 2004. Nepal still a hotspot for illegal wildlife traders. The Kathmandu Post, April 27.

Kellert, S. R., J. N. Mehta, S. A. Ebbin, and L. L. Lichtenfeld. 2000. Community natural resource management: Promise, rhetoric, and reality. Society and Natural Resources 13:705-715.

Khatri, T. B. 1993. Status and food habits of nilgai (Boselaphus tragocamelus) in Royal Bardia National Park, Nepal. Unpublished M. Sc. Thesis, Agricultural University of Norway, As, Norway.

Kremen, C., A. M. Merenlender, and D. D. Murphy. 1994. Ecological monitoring: a vital need for integrated conservation and development programs in the tropics. Conservation Biology 8(2): 388-397.

Krishna, A. 2002. Creating and harnessing social capital. In: social capital: a multifaceted perspectives. Available from http://emedia netlibrary.com

Lewis, D. M., and A. Phiri. 1998. Wildlife snaring - an indicator of community response to a community based conservation project. Oryx 32 (2): 111-121.

Mahapatra, A., and C. P. Mitchell. 1997. Sustainable development of non-timber forest products: implication for forest management in India. Forest Ecology and Management 94: 15-29.

Mainali, K. P. 2005. Sharp decline in Nepal's rhino population. Frontiers in Ecology and Environment 5(3): 239.

Martin, P. S., and C. Szuter. 1999. War zones and game sinks in Lewis and Clark's west. Conservation Biology 13(1): 36-45.

McNeely, J. A. 1993. Economic incentives for conserving biodiversity: lessons from Africa. Ambio 22 (2-3): 144-150.

Mehta, J. N. 1996. Park-people interface in Parsa Wildlife Reserve, Nepal. TRI News: A Journal of the Tropical Resource Institute 15: 11-12.

Mehta, J. N. and J. T. Heinen 2001. Does community-based conservation shape favorable attitudes among locals? An empirical study from Nepal. Environmental Management 28 (2): 165-177.

Mehta, J. N., and S. R. Kellert. 1998. Local attitudes toward community-based conservation policy and programmes in Nepal: a case study of the Makalu-Barun Conservation Area. Environmental Conservation 25 (5): 320-333. 
MFSC. 2004. Terai Arc Landscape-Nepal: strategic plan 2004-2014. His Majesty Government of Nepal, Ministry of Forests and Soil Conservation, Kathmandu, Nepal.

Mishra, H. R. 1982. Balancing human needs and conservation in Nepal's Royal Chitwan National Park. Ambio 11 (5): 246-251.

Muchagata, M., and K. Brown. 2000. Colonist farmers' perceptions of fertility and the frontier environment in eastern Amazonia. Agriculture and Human Values 17:371-384.

Mukwekwerere, M.C. 1996. Non-timber forest products: their role in subsistence economics in Zimbabwe. The Zimbabwe Science News 30 (2): 65-67.

Nepal, S. K., and K. E. Weber. 1995. Prospects for coexistence: wildlife and local people. Ambio 24: 238-245.

Nepali, S. 2005. Impacts of a political conflict in conservation and livelihoods. Unpublished report submitted to WWF- Nepal Program, Kathmandu, Nepal.

Nepstad, D., I. Brown, L. Luz, A. Alechandre, and V. Viana. 1992. Biotic impoverishment of Amazonian forest by rubber tapper, loggers, and cattle ranchers. Advances in Economic Botany 9:1-14.

Newmark, W. D., N. L. Leonard, H. I. Sariko, and D. G. M. Gamassa. 1993. Conservation attitudes of local people living adjacent to five protected areas in Tanzania. Biological Conservation 63: 177-183.

Noss, A. J. 1997. Challenges to nature conservation with community development in central African forests. Oryx 31 (3): 180-188.

NTB. 2005. Tourissm Resource Center-Downloads. Nepal Tourism Board, Kathmandu, Nepal. Available from http://www.welcomenepal.com/arrivalstat.asp (accessed on May 20, 2005)

Oates, J.F. 1995. The dangers of conservation by rural development - a case-study from the forests of Nigeria. Oryx 29 (2): 115-122.

Ostrom, E. 1990. Governing the commons: The evolution for collective action. Cambridge University Press, Cambridge.

Parry, D., and B. Campbell. 1992. Attitudes of rural communities to animal wildlife and its utilization in Chobe enclave and Mababe depression, Botswana. Environmental Conservation 19 (3): 245-252. 
Phuyal, S. 2005. Big cats endangered. The Kantipur Publication, Kathmandu, Nepal. Available from http://www.kantipuronline.com/ (accessed on May 20, 2005).

Phuyal, S., and S. Adhikari. 2003. Makalu Barun: where illegal wildlife traders are defying Maoist rule. The Kathmandu Post, January 30.

Plumptre, A. J., J. B. Bizumuremi, F. Uwimana, and J. D. Ndaruhebeye. 1997. The effects of the Rwandan civil war on the poaching of ungulates in the Parc National des Volcans. Oryx 31: 265-273.

Price, S. V., editor. 2003. War and tropical forests: conservation in areas of armed conflicts. Food Products Press, NY.

Raj, P. A. 2004. Maoists in the land of Buddha: an analytical study of the Maoist insurgency in Nepal. Nirala Publications, New Delhi, India.

Raut, Y. 1997. Concept of stocking rate and carrying capacity: high stocking rate and its effects on pasture production and ecology. Pages 16-34 in A text book of animal husbandry I: pasture production. The Department of Livestock Services, Ministry of Agriculture, Kathmandu, Nepal.

Regmi, U. R. 2000. Status of tiger and livestock depredation in Royal Suklaphanta Wildlife Reserve, Nepal. Unpublished M. Sc. thesis, Agricultural University of Norway, As, Norway.

Richards, M. 1996. Protected areas, people and incentives in the search of sustainable forest conservation in Honduras. Environmental Conservation 23(3): 207-217.

Robinson, J. 1993. The limits to caring: sustainable living and the loss of biodiversity. Conservation Biology 7 (1): 20-28.

Sah, J. P. 2002. Vegetation dynamics and their implications for the management of wetlands in the lowlands of Nepal. Unpublished $\mathrm{PhD}$ dissertation, Floirda International University, Miami, USA.

Sah, J. P., and J. T. Heinen. 2001. Wetland resource use and conservation attitudes among indigenous and migrant peoples in Ghodaghodi Lake area, Nepal. Environmental Conservation 28(4): 345-356.

Schreckenberg, K. 1999. Products of managed landscape: non-timber forest products in the parklands of the Bassila region, Benin. Global Ecology and Biogeography 8: 279-289. 
Sekhar, N.U. 1998. Crop and livestock depredation caused by wild animals in protected areas: the case of Sariska Tiger Reserve, Rajasthan, India. Environmental Conservation 25 (2): 160-171.

Sembajjwe, W. S. G. 1995. Sacred forests in Ganda society. Uganda Journal 42: 32-44.

Sharma, U. R., and P. B. Yonzon, editors. 2005. People \& Protected Areas in South Asia. Resources Himalaya Foundation, Kathmandu and IUCN World Commission on Protected Areas, South Asia.

Shrivastava, R. J. 2002. Natural resource use and park-people relations at Kaziranga National Park and World Heritage Site, India. Unpublished M.Sc. thesis, Florida International University, Miami, USA.

Sierra, R. 1999. Traditional resource-use systems and tropical deforestation in a multiethnic region in North-west Ecuador. Environmental Conservation 26 (2): 136-145.

Southgate, D., and H. L. Clark 1993. Can conservation projects save biodiversity in South America? Ambio 22 (2-3): 163-166.

Sperling, L. 2001. The effect of the civil war on Rwanda's bean seed systems and unusual bean diversity. Biodiversity and Conservation 10: 989-1009.

Spinage, C. 1998. Social change and conservation misrepresentation in Africa. Oryx 32 (4): 265-276.

Straede, S., and F. Helles 2000. Park-people conflict resolution in Royal Chitwan National Park, Nepal buying time at high cost? Environmental Conservation 27(4): 368-381.

Studsrod, J. E., and P. Wegge. 1995. Park-people relationships: the case of damage caused by park animals around the Royal Bardia National Park, Nepal. Environmental Conservation 22(2): 133-142.

Thapa, D., and B. Sijapati. 2003. A kingdom under siege: Nepal's Maoist insurgency, 1996 to 2003. The Printhouse, Kathmandu, Nepal.

The Kathmandu Post. 2004. Huge cache of animal skins, bones recovered. The Kathmandu Post, March 30.

Tripathy, B. 2003. Poaching reduces red panda population. The Kathmandu Post, December 30 . 
The Rising Nepal. 2003. Security negligence cause of rhino deaths. The Rising Nepal, March 1.

The Rising Nepal. 2004. Nepal transit point of wildlife trade in SA. The Rising Nepal, July 15 .

Vogel, G. 2000. Conflict in Congo threatens bonobos and rare gorillas. Science 287: 2386-87.

Wunder, S. 2000. Ecotourism and economic incentives - an empirical approach. Ecological Economics 32:465-479.

Yonzon, P.B., and M.L. Hunter Jr. 1991. Cheese, tourists and red pandas in the Nepal Himalayas. Conservation Biology 5(2): 196-202. 


\section{APPENDICES}

Appendix 1. The Maoist People's War and Conservation

\subsection{Introduction}

Developing countries are confronted with many challenges to conserve their rich biodiversity. Currently, civil war is one of the most serious problems jeopardizing conservation efforts. The frequency of wars has increased during the past 50 years. There were more than three times as many on-going wars in the 1990s than in the 1950s (Kane 1995; Collier 2000). Instances of war, civil strife, and political instability are rife in Asia, Africa and Latin America (Hamilton et al. 2000; Davalos 2001; Dudley et al. 2002; Price 2003). These wars are endemic to developing countries where biodiversity is rich and pose problems for conservation (Hamilton et al. 2000; Sperling 2001). There is a vicious link between civil war and environmental degradation. War causes serious environmental degradation that ultimately escalates pressures on natural resources, which in turn causes shortages of resources and stokes more fuel for civil war (Dudley et al. 2002). Conservation is very important in developing countries where rich biodiversity, political instability, a low priority in political agenda, and a dearth of financial resources to meet basic needs of large populations interact in a very intricate fashion, challenging conservation science. Armed conflict is detrimental to conservation (Davalos 2001); during or after the war environmental considerations are not a top priority (Kanyamibwa 1998).

Among developing countries, Nepal has been in the forefront for conservation, however, the Maoist People's War has been a major setback in recent years. The Maoist insurgency 
began in 1996, six years after the restoration of multiparty democracy. There is no single explanatory factor attributed to the cause of insurgency. However, the ignorance of democratic governments to recognize the plurality of Nepali society has served the insurgency. A majority of rural people felt that they are discriminated against in ethnicity, caste, language, and religion by the state. Even after the restoration of democracy, inequalities in socioeconomic structures such as widespread poverty, caste/ethnic/gender discrimination, political/social oppression, and corruption were prevalent and they have stoked fuel for the war (Thapa \& Sijapati 2003; Karki \& Bhattarai 2004). During the past nine years, about 12,119 people have died fighting for either the government or the rebellion (Karki \& Bhattarai 2004). The consequences of the war permeated into all spheres of the nation.

One of the most obvious impacts is on the socio-economic sector. Most development activities came to an abrupt halt in many parts of rural Nepal. The Government has slashed development funds and diverted funds to security expenditures. Rebel attacks on many hydropower plants, access facilities, communication networks and development projects has caused substantial economic loss. Economic indicators plunged and the war has had devastating effects on social and cultural aspects of society. Large numbers of people are fleeing from Maoists strongholds to different parts of the country and, on some occasions, outside the country. Abandoning huge tracts of agricultural field in mountain districts has increased the food deficit. The livelihood of many poor people depends on harvesting non-timber forest products. When the insurgency spread through rural areas, local people are deprived of these resources. They have no alternative means 
for subsistence so they are forced to seek employment opportunities outside, which causes migration en masse. Many cultural practices were abandoned because of Maoist injunction, or simply out of fear.

There are many studies on socioeconomic consequences of the Maoist People's War (Thapa \& Sijapati 2003; Hutt 2004; Karki \& Bhattarai 2004; Raj 2004). So far, there has been no study on impacts of the war in the environment sector. This is because acquisition of relevant environmental data of war-inflicted areas is very difficult (Sperling 2001). My analysis is based on a review of published literature, news in the local press, direct observations during field visits, and discussions with local people and conservation practitioners.

\subsection{Sabotage of Conservation Agency}

The top-level conservation agency of Nepal is the Ministry of Forests and Soil Conservation. It has four departments: the Department of National Parks and Wildlife Conservation (DNPWC) administers a network of protected areas (PAs), the Department of Forests (DoF) looks after government forests outside protected areas including community forests, the Department of Soil and Watershed Conservation (DSWC) is in charge of watershed management and control of soil erosion, and the Department of Plant Resources is concerned with research and policies for plant conservation. Since the inception of civil strife, these agencies are under siege and tremendous damage to infrastructure has threatened institutional stability. To date, the DNPWC manages 16 PAs of four different categories (nine national parks, three wildlife reserves, three 
conservation areas, and one hunting reserve), which cover about $18 \%$ of the country's total area. So far, the Maoist rebels have destroyed 47 physical structures of the DNPWC (Budhathoki 2003), which seriously undermines the integrity of park management. Rebels vandalized two PAs: Dhorpatan Hunting Reserve (DHR) and Makalu Barun National Park (MBNP; Phuyal \& Adhikari 2003; Gautam 2004). They forcibly evicted all staff, took valuable communication and other equipment and took charge of the area. These areas are important habitats for endangered wildlife such as musk deer Moschus moschiferus and snow leopard Panthera uncia (Chaudhary 1998). The conservation status of these areas is largely unknown as is the case of resource exploitation in rebel's territory. Throughout the world, dedicated park staff have lost their lives for conservation in times of civil strife (Hart \& Hart 1997; Hamilton et al. 2000). Maoist rebels killed park staff of Royal Suklaphanta Wildlife Reserve and Parsa Wildlife Reserve in ambushes. There have been reports of skirmishes between rebels and security force in the two World Heritage sites: Everest National Park and Royal Chitwan National Park. After these incidents, patrolling inside parks and reserves was seriously diminished and so is the visitation by tourists.

Forests outside the network of PAs are important for biodiversity conservation because they provide adjunct wildlife habitats and also serve as corridors for isolated PAs. Still large tracts of forests are under the jurisdiction of the DoF, and it manages these forests through its district and regional offices. Since the advent of the People's War, the DoF is on the top of the list of rebel targets. As of January 2003, Maoist rebels destroyed 22 district-based offices, 39 area offices, 217 range posts, two training centers and two 
armed security camps (Table 23). One of the strategies of rebels is to compel the government to withdraw its presence from forested areas and use them as shelter and training centers.

Conservation agencies in developing countries have been faced with chronic lack of funds, equipment and trained staff, and are frequently institutionally unstable (Heinen \& Kattel 1992; Hamilton et al. 2000). The rebel's brutal act of killing park staff, damaging physical infrastructure and forcing staff to leave will hamper the institutional strengthening and stability of such conservation agencies. These will have short and longterm detrimental impacts on conservation and may jeopardize past achievements.

\subsection{Community-based Conservation}

During the 1990s, Nepal embarked on community-based conservation (CBC) for natural resource management and conservation. The $\mathrm{CBC}$ approach got momentum when conservation areas, buffer zones, and community forests were recognized by legislation and subsequently instituted. $\mathrm{CBC}$ is hailed as a critical approach in areas of political instability (Hamilton et al. 2000) because local people express resentment towards strictly protected parks and reserves (Heinen 1993). Although the $\mathrm{CBC}$ approach is more resilience than the 'fortress and fine' approach, it is still not secure during civil strife. All three conservation areas: Annapurna, Manaslu, and Kanchanjunga, are impacted to varying degrees by civil strife (Budhathoki 2003). The southern flank of Annapurna Conservation Area (ACA) is essentially under rebel control. Of seven field-based offices, four that lie in southern ACA were bombed and project staff deserted (Dhakal 2004). 
Maoist rebels mercilessly killed three local conservation leaders who were proponents of Annapurna Conservation Area Project (ACAP). These incidents intimidated local people, who no longer come forward to participate in conservation and development projects. The integrated conservation and development projects that ACAP has implemented with active participation of local people, are now virtually ceased. Institutional strengthening in buffer zones of lowland protected areas is also seriously curtailed. Of 29 grassroots institutions surveyed in two buffer zones of the Western Terai, 10 were not holding regular meetings. This has seriously hampered active participation by local people.

Another successful model of $\mathrm{CBC}$ is community forestry. Community forests have accomplished the objective of restoring denuded forests in mountain districts, and are taken as an exemplary model for participatory conservation in developing countries. To date, some 12,000 registered Forest User Groups (FUGs) are managing 850,000 ha of forests under a community forests regime in Nepal (Gilmour 2003). The grassroots institution founded on FUGs has been facing many challenges. Most community forests are in hill and mountain districts that are under Maoists control and FUGs must tacitly agree with Maoists rules that are not conservation-friendly. Local press reported that the Maoist rebels were extorting up to $70 \%$ of the revenue generated by community FUGs in those areas. In some instances, rebels infiltrated FUG executive committees and earmarked revenues to support the insurrection. No matter how rebels acquired funds garnered by FUGs, the development fund - a byproduct of the conservation program - is misused for warfare. This has severe impacts on sustainable development of rural areas and survival of FUGs as a viable institution for resource management. There are legal 
complications when FUGs are dysfunctional. When civil strife challenges the legitimacy of the Government in rural areas, then present FUGs will become disenfranchised as legitimate forest managers because they function in collaboration with, and under the umbrella of, district forest offices (Gilmour 2003). This is a serious problem for community forestry programs in mountain districts because most are under rebel control. Community forestry was more successful in the mountain districts of Nepal than in other areas. No research has been done to date on the impacts of civil strife on community forestry programs and the functioning of FUGs in Maoist strongholds.

The war pervades all spheres of society and seriously disintegrates the capacity of local institutions for natural resource management (Goldstone 1996). There have been very few studies on how local institutions thrive in times of civil strife. The pervasive hypothesis is 'popular participation' by local people, but research elsewhere shows that local communities are not willing to participate in war-inflicted areas (Davalos 2001). If this is true in all or most war-inflicted areas, the efficacy of the $\mathrm{CBC}$ approach will be seriously undermined.

\subsection{Wildlife Populations}

Some authors suggest that historical warfare has been beneficial for conservation based on the findings that game was abundant in buffer or war zones (Martin \& Szuter 1998). However, there is no dispute in the claim that modern wars and civil strife are detrimental to endangered megafauna. During periods of war, there have been massive declines in populations of elephants and large ungulates in Uganda (Eltringham \& Malpas 1993), 
extirpation of wild ungulate and carnivore populations in Afghanistan (Formoli 1995), and poaching of bonobo Pan paniscus and gorilla Gorilla gorilla in the Republic of Congo (Vogel 2000). Wildlife populations plummeted directly from opportunistic, deliberate and random shooting by rebels, security forces, and poachers, and indirectly from landmines.

Endangered species such as red panda Ailurus fulgens, snow leopard, musk deer, onehorned rhinoceros, Bengal tiger, Cheer Pheasant Catreus wallichii are falling prey to poachers and rebels in Nepal. There has been a precipitous decline in the blue sheep Pseudois nayaur population from 2200 individuals in 2002 to 563 individuals in 2004 in the DHR (Gautam 2004). Maoist rebels are shooting these animals to feed their cadres. Illegal activities of poachers are escalating in the reserve: 53 and 33 traps were recovered in 2002 and 2003 respectively, and one red panda was caught in a trap (Tripathy 2003). The recent census of one-horned rhinoceros shows a bleak future for these animals. The population of rhinoceros decreased from 544 in 2000 to 372 in 2005 in and around the RCNP, home to most of Nepal's rhinoceros (Mainali 2005). The death toll of rhinoceros is steadily increasing, 33 rhinoceros died in 2000, 42 in 2001 and 55 in 2002, with an average mortality rate of $6.32 \%$ per year for the period of 2000-05 (Chapagain 2002). At least 94 rhinoceros were killed by poachers since 2000. Tigers are also meeting the same fate: six tigers were killed in 2002 while eight tigers were killed in 2003 (The Rising Nepal 2003). Escalating of poaching inside protected areas is attributed to lax security and inefficiency of anti-poaching units (APU). The collaborative effort of the park, NGOs and local people has created APUs in RCNP and RBNP to garner conservation 
intelligence. Despite hefty donor funding, APUs failed to curb poaching in these areas (Mainali 2005). At present, wildlife poaching is a serious threat. So far, there have been no records of wildlife killed by landmines in Nepal.

In the past, elites who had licensed arms hunted wildlife in public forests whenever an opportunity arose. This hunting seriously depleted wildlife populations outside protected areas. However, the situation changed when the Maoists usurped licensed arms. Furthermore, the Government ordered that all licensed arms were to be submitted to security forces when the plundering of arms escalated. Since hunters lost arms, the frequency of hunting decreased sharply. This had a positive impact on the resurgence of common species such as barking deer, common leopard, and pheasant in public forests, which were once pushed towards local extinction. However, conservationists are skeptical about population increase of endangered species in rebel-controlled areas. Scientific data on population trends of wildlife remains obscure. It is not feasible to undertake scientific research in wildlife habitats that are under guerrilla control (Davalos 2001).

\subsection{Law and Regulations}

Nepal is one of the few countries in the world to deploy soldiers (Royal Nepalese Army) for the protection of parks and reserves (Budhathoki 2003). They have been effective in providing able protection of these areas (Heinen \& Kattel 1992), but are inadequate to maintain law and order in times of political instability. Security of protected areas receives a lower priority since the Government declared a state of emergency in 2001 to 
curb the Maoist insurrection. Since then, there has been a $70 \%$ reduction in guard posts inside protected areas. Of 112 guard posts, only 34 are now occupied to render protection of parks throughout Nepal (Nepali 2005). Many soldiers were deployed to fight against the insurgents rather than poachers. The frequency of patrolling has been reduced in temporal and spatial scales within protected areas. This has emboldened poachers, smugglers and illegal trespassers to abuse protected areas. The withdrawal of army posts has resulted in the widespread breakdown of law and order in and around protected areas.

Nepal is party to many international conservation accords such as the Convention on International Trade in Endangered Species of Wild Fauna and Flora (CITES), the Convention on Biodiversity, the World Heritage Convention, and the Ramsar Convention. Implementation of and compliance with these treaties have been hindered due to a lack of national implementing legislation (Heinen \& Chapagain 2002), and in recent years, instances of violations of these treaties have increased because of civil strife. International poachers consider Nepal a safe haven for illegal trade of wildlife parts because the Maoist insurgency paralyzed law-regulating agencies. Kathmandu has became a hub where bones, skins, furs and other body parts of endangered wildlife are traded. Although Nepal is not a major consumer of wildlife parts, poachers are abusing its territory as a transit point for illegal trade with China and India (The Rising Nepal 2004). On April 23, 2004, police personnel disguised as consignors arrested an illicit trader with 85 pieces of leopard skins and 38 of that of otter in the capital, Kathmandu (KhatryChhetri 2004). He bought these skins in India and intended to export to the China. A huge cache of wildlife parts was recovered on March 29, 2004 near the Nepal-Tibet border. 
Security personnel seized 172 pieces of rhinoceros skins, seven tiger skins, six skins of unidentified cats and 165 pieces of tiger bone (The Kathmandu Post 2004). Similarly, security personnel seized 32 tiger, 579 leopard and 666 otter skins en route to Tibet in October 2003 (Khatry-Chhetri 2004). These species are listed in CITES Appendices so are trade-regulated, but their skins or bones fetch hefty price in illicit international markets. Therefore, the illegal trade in wildlife parts is threatening the survival of many endangered species. The recent survey in Sariska Tiger Reserve in India found that not a single tiger was left alive there due to poaching (Phuyal 2005). These activities violate CITES and national wildlife laws of Nepal, India, and China. Better coordination and cooperation between the three countries will facilitate the enforcement of national laws and CITES. When the host country is grappling with civil strife, the enforcement of international conservation accords and national conservation laws is ineffective.

It is common to include biodiversity and conservation rhetoric in the political agenda by rebels (Alvarez 2003). So far, the Maoists in Nepal have not proclaimed their environmental policies fully. Their environmental policies are guided by short-term benefits accrued from the sale of valuable resources and the protection of forest cover for hideouts. Protecting forests serves their interests because forests are indispensable hideouts in guerilla wars (Davalos 2001). However, this does not reflect any incorporation of sound environmental policy in their political agenda. In the high Himalayas, the Maoist rebels are facilitating the sale of trade-regulated aromatic and medicinal plants to collect revenue. They are issuing permits to collect Yarsa Gompa Cordyceps sinensis, Panch Awale Dactylorhiza hatagirea, and Loth Salla Taxus baccata 
(N. Lama, ACAP officer, personal communication). Over-harvesting of these species is pushing them towards local extinction. For monetary benefits, Maoists are colluding with poachers and smugglers in illicit trade of endangered animals and plants. Illegal activities are common in protected areas and public forests in absence of authorities. Although there are examples of rebel groups helping to conserve forests (Kaimowitz \& Faune 2003), there has been no obvious conservation benefits of the Maoist People's War in spite of this rhetoric of forest conservation (Heinen \& Shrestha 2005).

\subsection{Some Economic and Social Impacts}

Revenue generated in PAs for the years 2000/01, 2001/02 and 2002/03 were 1796, 912, and 802 thousands US dollars, respectively (DNPWC 2005). There has been a $40-60 \%$ decline in park entry fees in that period (Nepali 2005). Mountain parks such as Langtang, Everest, and SheyPhoksundo are famous for trekking and Terai parks such as RCNP and RBNP are renowned for wildlife safaris. Since there has been a tremendous decrease in tourist arrival at the national level (Figure 10), these parks also lost substantial revenue. Trophy hunting was the main source of revenue generation in DHR and mountaineering was in MBNP, but currently these areas are under rebel control so do not contribute to the central treasury. Considering the volatile nature of the tourism market, it is suggested that income from ecotourism should be complementary, but not substitutive for conservation (Wunder 2000). The government used to collect substantial revenue through the sale of timber and non-timber forest products from productive forests of Terai. When Maoists rebels took over most of these forests, there was a sharp decline in these revenues as well. The conservation agency is chronically under-funded (Heinen \& Kattel 1992), and when 
revenue generated by parks and productive forests plunged further, the allocation of government funds for conservation greatly decreased. One of the strategies used by rebels worldwide is taking control over revenue-generating sources so that the state financially bankrupts (Davalos 2001). Following this strategy, the Maoist rebels in Nepal have been generating revenues from the use of natural resources to partially fund the insurgency at a loss for conservation.

War brings about many social problems that ultimately impact natural resource conservation and management. In the early $1990 \mathrm{~s}$, Bhutanese refugees were fleeing to the eastern Terai of Nepal, and after 1996, many people who were displaced from mountain districts by the Maoist People's War migrated to the Western Terai (Heinen \& Shrestha 2005). These large-scale influxes of immigrants increased pressure on resources and hasten exploitation. Research elsewhere shows that plundering resources by rebels compel local people to harvest more (Plumptre et al. 1997). Local people are highly discounting the total value of biodiversity due to an uncertain future created by civil strife. Taking advantage of the disorder and confusion, they are exploiting endangered plants and animals for either subsistence or commercial purposes. Through out the world, natural resources are abused by guerrillas, military forces, local people and refugees during and subsequent to periods of war and civil strife (Dudley et al. 2002). Religious faith may garner support for conservation. Sacred forests thrived in Uganda during civil unrest (Sembajjwe 1995). In many places, people have favorable attitudes towards wildlife even though they cause substantial crop and livestock damages (Sekhar 1998). However, religious faith and cultural harmony slowly deteriorate when civil strife creates 
political chaos. In the name of social reform, the Maoists of Nepal outlawed many religious and cultural practices that were conservation friendly and previously checked over-exploitation of resources (Karki \& Bhattarai 2004).

\subsection{Synthesis and Conclusion}

A decade of civil strife is beginning to have far-reaching environmental consequences in Nepal. Damages to physical facilities, take over of protected areas and forests, and killing of staff by Maoist rebels are seriously hampering the stability of the conservation sector. In the absence of stringent law enforcement, poachers are taking a large toll on many endangered species. The future of one-horned rhinoceros and Bengal tiger is bleak in Nepal if the current level of poaching remains. Escalating wildlife trade and the Government's negligence of the conservation sector violates international conservation accords and results in ineffective implementation of national wildlife laws. The country's dependence on tourism to fund conservation programs also has deleterious impacts on conservation. The conservation agency has been chronically under funded, and the situation exacerbated when the volatile tourism market suffered from the insurgency. In addition, the Maoist rebels are abusing natural resources to support their insurgency.

Most conservation legislation, rules, regulations and modalities are crafted in periods of political stability. One of the lessons learned from on-going civil strife is that legislation and models are inadequate to address the multifaceted issues of conservation in times of political instability. The deployment of soldiers in protected areas during civil strife has not rendered able protection in Nepal because they were withdrawn from parks and 
reserves to fight the Maoist rebels. The time is right to contemplate the role of Royal Nepalese Army in parks protection and explore alternative institutional mechanisms that could be more effective to provide security to parks and reserves.

The $\mathrm{CBC}$ approach has been, in general, more resilient than the 'fortress and fine' approach for conservation, but is not impervious to civil strife. Rebels are extorting funds from community forest user groups, kill local conservation leaders and bomb NGO offices that support local people. In spite of these adversaries, many grassroots institutions have thrived in civil strife because local people have favorable attitudes towards the $\mathrm{CBC}$ approach and extend their support. So far, there is no example of third party involvement in conservation by collaborating with both the rebels and the Government. The anti-imperialist policy (ban on NGOs and INGOs) of the rebels makes it hard for the involvement of the international conservation community to support conservation.

The fate of Nepalese conservation efforts depends on the duration of this uncertain period and its consequences on the political, social, and economic sectors. The problem is intricate and there are no quick fixes. Although it has had recent negative impacts on conservation efforts achieved over the past three decades, it also provides an opportunity to explore more robust conservation models. Like biodiversity, civil wars and political instability are common in developing countries. To address the issue, strategies should be explored at local levels with national and international support. 
Your participation in this survey is voluntary. You will neither get any direct monetary benefits for participating nor penalized for not answering some or all of the questions. Any information gathered in this survey will be only used for the purposes of research. The interview is completely confidential; your name will not be associated with your answers. The purpose of this survey is to evaluate resource use patterns and conservation attitudes among local people in the Western Terai Landscape, Nepal. Your cooperation will help policy makers and planners make informed decisions.

Name of interviewer:

Date survey:

Household identification number:

Village name:

\section{Respondent's Ideographic Data:}

Gender: Male Female

Age: Ethnicity (Caste):

Education:

Occupation:

Information about Household Members:

Please, tell about gender, age, education and occupation of your household members

\begin{tabular}{llllll}
\hline S. No. & Household members & Gender & Age & Education & Occupation \\
\hline 1 & & & & \\
2 & & & \\
3 & & & \\
4 & & & \\
5 & & & \\
6 & & & \\
7 & & & \\
8 & & & \\
\end{tabular}

\section{Migration:}

Have you migrated to this place from elsewhere? Yes: No:

From where have you migrated to this place?

A district in mountain

Other villages of the same district
A district in the Terai

Others

When did you migrate here? years ago.

What was the reason to migrate here? 
Landlessness

Unemployment Insufficient land

Under Government's Scheme

Others

\section{Landholding Size and Tenure Status:}

Do you have plots for farming? Yes/size

No

What is the status of land?

Private registered land -.--..-.

Pubic land without title

Feudal land

Others

Do you get enough agricultural products to support your family for whole year?

Yes --.---.--

No

If no, how many months do you get shortage of food, not fulfilled from your agricultural products? Months.

What are alternate sources of income to fulfill your requirements?

Government employment

Pension ------

Business ------

Paid labor

Remittances

Others (Specify)

\section{Livestock Holding:}

Do you own any livestock? Yes

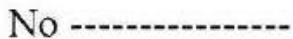

What kind of livestock species and how many of them do you have?

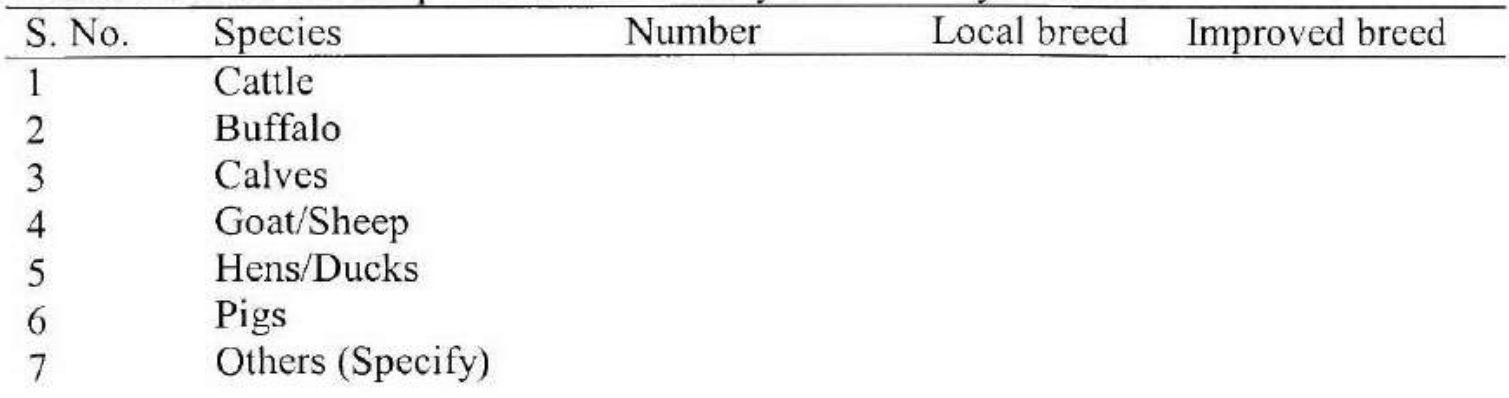

\section{Resource Uses:}

What kind of materials do you bring from the National Park or National Forest? If you bring any thing, please give an estimate of resources harvested. 


\begin{tabular}{lll}
\hline S. No & Material Types & Quantity in local units \\
\hline 1 & Fodder \\
2 & Fuelwood & \\
3 & Thatch grass \\
4 & Leaf litter \\
5 & Medicinal herbs \\
6 & Edible items (foods) & \\
7 & Timber \\
8 & Others (Specify)
\end{tabular}

From where you bring fodder for your livestock?

Own farms ------ $\quad$ Buffer zone, protected or national forest

How many days per week do you go to forests to bring fodder? days.

About how may fodder tress do you have on your private land?

Where do you take your livestock for grazing?

Forests

Private farms

Stall-fed

Public grazing lawns

What kind of cooking stove do you use in your house?

Simple mud stove --------- Improved mud stove --------

Kerosene stove ------- $\quad$ Bio-gas -----------

From where do you get fuel wood?

Private farm

Other forests

From market

Drift wood

Others

Do you have problems to get enough fuelwood? Yes

No

If yes, what do you think could be the best way to solve the problem?

Free access to existing forest

Private plantation
Community forests

Access to improved stove 
Any sales or purchases of forest products in last 12 months?

Forest product sold Amount sold Sale price/unit Where sold?

Forest product bought Amount bought Buying price/unit Where bought?

\section{Conservation Attitudes:}

Different people who live in this area hold very different opinions about the park or program. Here are a few of the things that people say about the park or program. Will you tell me whether you agree or disagree with them.

\begin{tabular}{|c|c|c|c|}
\hline S. No. & Statements & Agree & Disagree \\
\hline 1 & $\begin{array}{l}\text { Forests around your village have decreased in recent } \\
\text { years. }\end{array}$ & & \\
\hline 2 & $\begin{array}{l}\text { It is responsibility of local people to protect natural } \\
\text { resources. }\end{array}$ & & \\
\hline 3 & $\begin{array}{l}\text { If there is unlimited access to forests for fuel wood and } \\
\text { fodder, forests will be disappeared soon. }\end{array}$ & & \\
\hline 4 & There are more wild animals now than ten years ago. & & \\
\hline 5 & $\begin{array}{l}\text { What people and their livestock need are more } \\
\text { important than saving plants and wild animals. }\end{array}$ & & \\
\hline 6 & $\begin{array}{l}\text { My living condition improved since the protected } \\
\text { area's creation. }\end{array}$ & & \\
\hline 7 & $\begin{array}{l}\text { After the establishment of buffer zone forests/reserve } \\
\text { you don't have problem of access to resources. }\end{array}$ & & \\
\hline 8 & $\begin{array}{l}\text { It is important to set aside a place for the animals and } \\
\text { plants to live in. }\end{array}$ & & \\
\hline 9 & $\begin{array}{l}\text { It is important to protect the animals and plants so that } \\
\text { our children may know and use them. }\end{array}$ & & \\
\hline 10 & $\begin{array}{l}\text { There is an equitable distribution of common pool } \\
\text { resources and benefits. }\end{array}$ & & \\
\hline 11 & You are willing to contribute for conservation cause. & & \\
\hline
\end{tabular}

\section{Participation and Benefits:}

Are you or any of your family members elected in any grassroots organizations?

No Yes (Mention the Name - )

Have you or your family members ever received any kind of trainings?

No (Which? $---)$ 
Are you benefited from any conservation organizations? (Benefits include free seedlings, vaccination, biogas/toilet construction support etc.)

No ------- Yes (Mention the items

Are you a member of saving-credit group?

No ------- Yes

Are you engaged in income generating activities promoted by NGOs?

No ------ Yes ------ (If yes how much do you earn per month? --------- NRs.)

\section{Miscellaneous:}

Are you satisfied with User Groups? Yes No

Are you suffering from wildlife damage? Yes No

Do you have any suggestions for conservation and sustainable development? 